\title{
A Comparison of Centralized and Decentralized Developmental Education Courses in Four Public Appalachian Community Colleges and Students' Perceptions Regarding the Seven Principles for Good Practice
}

Philip M. Keith

West Virginia University

Follow this and additional works at: https://researchrepository.wvu.edu/etd

\author{
Recommended Citation \\ Keith, Philip M., "A Comparison of Centralized and Decentralized Developmental Education Courses in \\ Four Public Appalachian Community Colleges and Students' Perceptions Regarding the Seven Principles \\ for Good Practice" (2011). Graduate Theses, Dissertations, and Problem Reports. 3027. \\ https://researchrepository.wvu.edu/etd/3027
}

This Dissertation is protected by copyright and/or related rights. It has been brought to you by the The Research Repository @ WVU with permission from the rights-holder(s). You are free to use this Dissertation in any way that is permitted by the copyright and related rights legislation that applies to your use. For other uses you must obtain permission from the rights-holder(s) directly, unless additional rights are indicated by a Creative Commons license in the record and/ or on the work itself. This Dissertation has been accepted for inclusion in WVU Graduate Theses, Dissertations, and Problem Reports collection by an authorized administrator of The Research Repository @ WVU. For more information, please contact researchrepository@mail.wvu.edu. 


\title{
A Comparison of Centralized and Decentralized Developmental Education Courses in Four Public Appalachian Community Colleges and Students' Perceptions Regarding the Seven Principles for Good Practice
}

\author{
Philip M. Keith \\ Dissertation submitted to the \\ College of Human Resources and Education \\ at West Virginia University \\ in partial fulfillment of the requirements for \\ the degree of \\ Doctor of Education \\ in
}

Educational Leadership Studies

Ernest Goeres, Ph.D., Chair

Sandra Bailey, Ed.D.

Elizabeth Jones, Ph.D.

Patricia Obenauf, Ph.D.

Richard Walls, Ph.D.

Department of Educational Leadership Studies

Morgantown, West Virginia 2011

Keywords: Developmental Education; Principles for Good Practice; Student Development

Copyright 2011 Philip M. Keith 


\begin{abstract}
A Comparison of Centralized and Decentralized Developmental Education Courses in Four Public Appalachian Community Colleges and Students' Perceptions Regarding the Seven Principles for Good Practice
\end{abstract}

Philip M. Keith

Developmental education courses have become a standard in community colleges in the United States. An overwhelming majority of these public two-year schools offer developmental courses to a wide array of students. At the same time, developmental programs are under a constant barrage of attacks from a variety of stakeholder organizations that view these courses as redundant in the public educational system. As a result, community college systems across the nation are striving to find the most effective and efficient means to offer these courses, to decrease the length of time students are spending in these courses, and to increase the numbers of students who transition into the regular college curriculum.

This study examined four research questions: first, the researcher attempted to determine if statistically significant differences existed between the perceptions of students attending centralized and decentralized developmental education courses in regard to their instructors' use of the principles for good practice; second, this study attempted to determine if there were statistically significant differences between students attending developmental education courses and instructors teaching in developmental education courses in regard to their perceptions of the principles for good practice occurring in these courses; third, this research attempted to determine if there were significant differences in the perceptions of students attending developmental English/writing courses and students attending developmental mathematics courses in regard to each of the seven principles for good practice; and finally, this research attempted to determine if there were significant differences between instructors' perceptions regarding the principles for good practice based on subject taught (i.e. English/writing and mathematics). Six community colleges were sampled to address the last three research questions; four of the six community colleges were used to address the first research question. A causal comparative methodology was used for this research. A MANOVA determined that statistically significant differences existed between groups regarding all four research questions. Subsequent analyses of variance found that students from the centralized and decentralized groups differed on five out of the seven principles for good practice, with the decentralized group rating their instructors higher on four out of the five principles where differences were detected. 


\section{Dedication}

This work is dedicated to my wife and best friend, Heidi Gabrielle Thompson. You are a beautiful artist, a beautiful mother, and a beautiful friend... "You and me together..."

And to my children, Lillian Belle Keith, Noam Gabriel Keith, and Baby-Boy-to-Be: I am thankful everyday to watch you grow, to have conversations with you, to play with you, and to entertain the many questions you ask about this world... I hope that this accomplishment will help you all someday realize that life-long-learning is a wonderful thing, and that you too can achieve anything you work hard at.

This work is also dedicated to the loving memory of my grandparents, Ralph Holman Keith (1911-1999) and Margaret Belle Keith (1921-1994). I rely greatly, everyday of my life, on the love, encouragement, and strength that you both provided me throughout my youth... if it were not for you both I do not know where I would be. Thank you!!

Lastly, I am a first-generation and non-traditional college student. For the most part, college was not supposed to be in my future... it was not something I had focused on in high school and certainly not something for which I'd prepared. To be honest, I wasn't sure what I would do with my life. I dedicate this work to all of those students who are high school dropouts, or first generation students, or non-traditionals, who, for some reason, have become inspired to take on the challenge of academia... my hat goes off to you!! You can do it!! 


\section{Acknowledgements}

One of the greatest things about being a part of the doctoral program at WVU has been the wonderful opportunity that I have had to work with so many great people. I am eternally grateful for the hard work and dedication of the following individuals:

Dr. Ernest Goeres: you are one of the finest men in all of academe. I am thankful for the guidance, laughter, and education you have provided me. You have always been accessible and have worked extremely hard to help me achieve my goals. Thank you!

Dr. Elizabeth Jones: thank you for your dedication to learning. I am extremely grateful for all of the help that you have provided me over the course of this program of study. Your guidance and feedback have helped to improve this work immensely.

Dr. Richard Walls: thank you for all of the help you have provided to improve my study ... and for reminding me about commas, coordinating conjunctions, and independent clauses!!

Dr. Patricia Obenauf: thank you for being a part of my committee. Your feedback and support have meant a great deal.

Dr. Sandra Bailey: there is no finer teacher out there. I appreciate the work that you do everyday to ensure that our schools are staffed with the best and brightest teachers possible. Your dedication to your students and learning is inspirational! Thank you for taking the time to help me pursue this goal.

I am immensely grateful to be surrounded by so many great friends and family members. You all have helped to inspire me in some way ... for this I am forever thankful. A special thank you goes out to my uncle and aunt, Jim and Amy Matheny... thanks for letting me crash at your place while I was out collecting data... I always enjoy the conversations. Heather, Dan, and 
Alice Brunton also deserve a big thanks for letting me crash at their place several nights while collecting data. You are all really great people!!

To my mom, sister, and brothers...I love you all. My mom instilled in me, early-on, an immense love for books and reading... thanks mom!! I would also like to thank Diana and Rue for all of their good wishes and support ... and to the rest of the Thompsons ... thanks for being a great family!!

To my dear friends Karen, Angie and the many other members of this doctoral program... thanks for all the good times!!! A special thanks is reserved for my dear friend Dennis McNaboe... thanks for all of your help!!

This research project was made possible through the support of the following people: Dr. Billie Unger, Dr. Bill Hightower, Dr. Chad Brown, Ms. Tondalaya Vanlear, Mr. Gary Appel, Dr. Michael Scott, Dr. Pat Huber, Ms. Judith Valade, and all of the instructors who so graciously opened up their classrooms to let me in. And last but not least, a tremendous thank you to all of the students who participated in this research study... this was because of you!!! Thank You!! 


\section{Table of Contents}

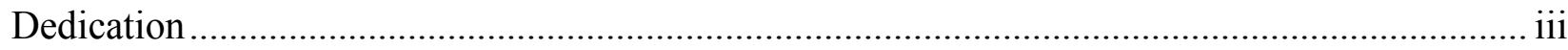

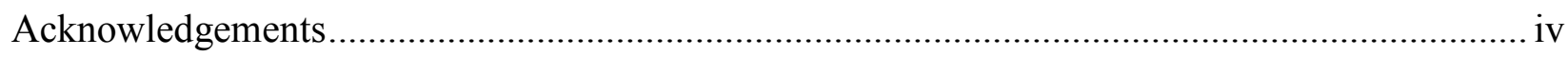

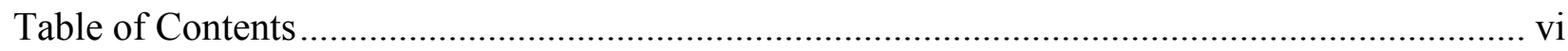

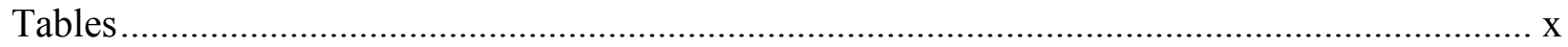

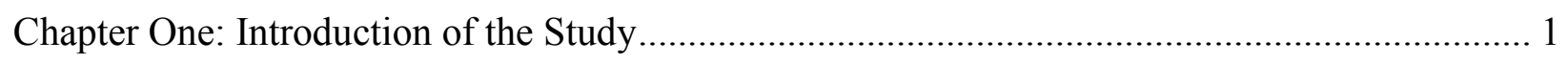

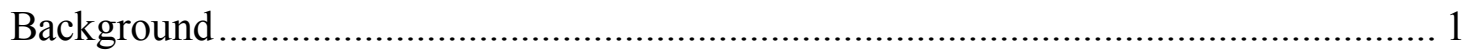

Statement of the Problem...................................................................................... 4

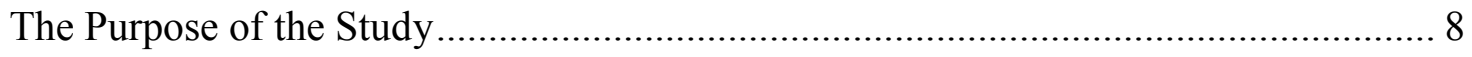

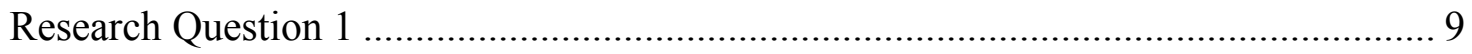

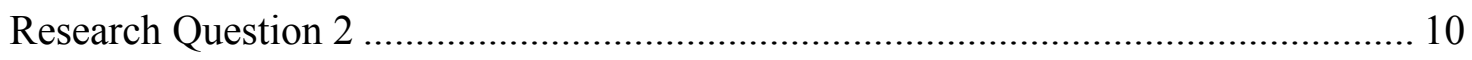

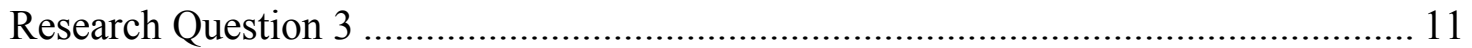

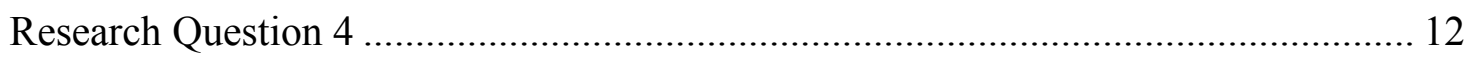

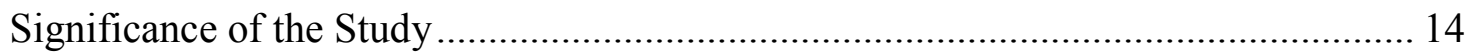

Definition of Terms ........................................................................................ 16

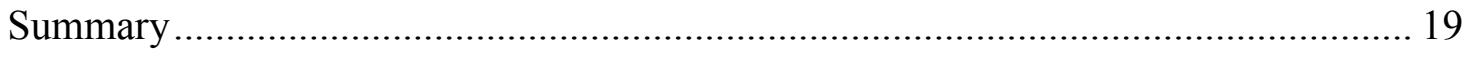

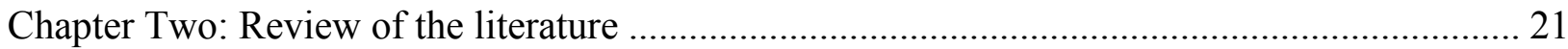

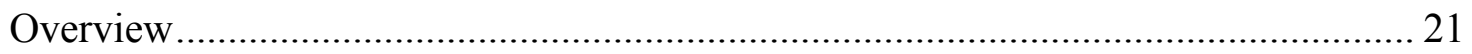

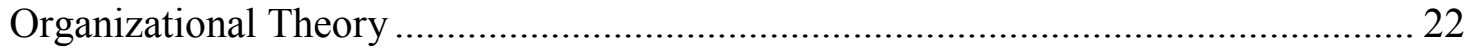

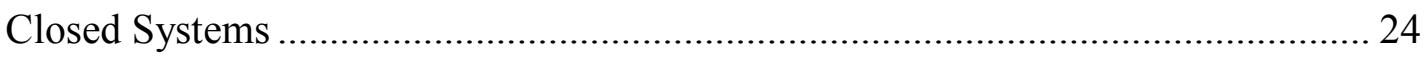

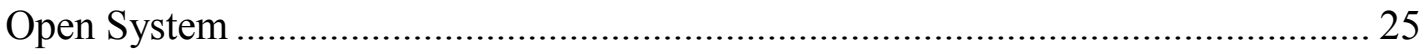

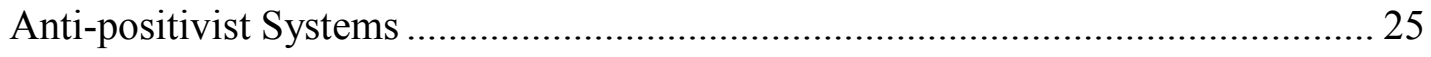

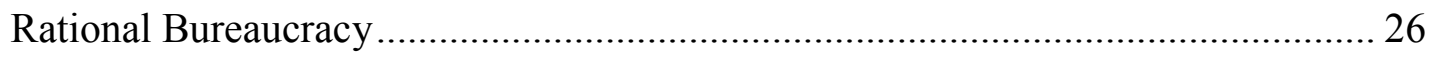

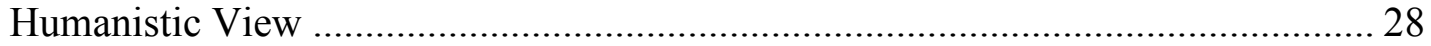




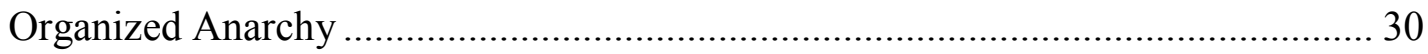

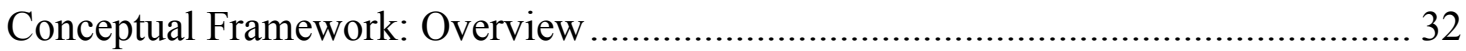

Centralized and Decentralized Developmental Education........................................ 33

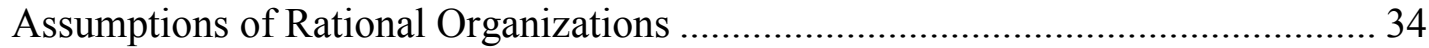

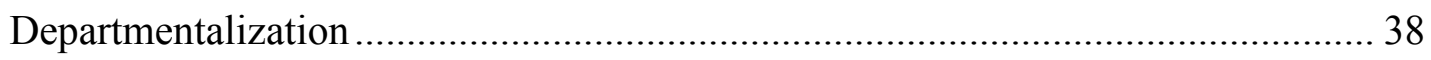

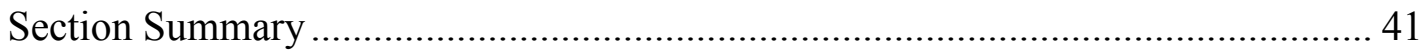

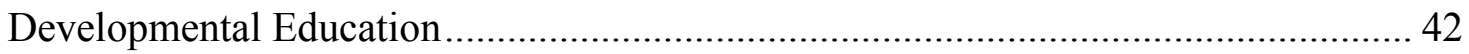

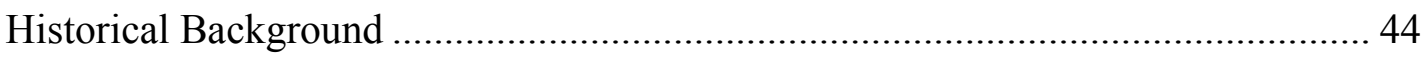

Chickering's Theory of Identity Development ........................................................ 47

Perry's Theory of Intellectual and Ethical Development......................................... 48

Astin's Theory of Student Involvement.................................................................... 49

Professional Organizations and Best Practices in Developmental Education .......... 50

Seven Principles for Good Practice in Undergraduate Education ................................ 53

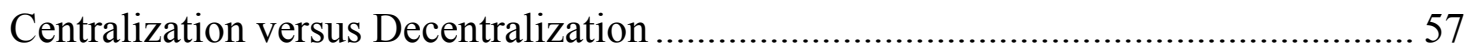

Soft Paradigmatic versus Hard Paradigmatic Disciplines ........................................... 58

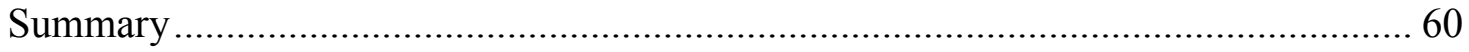

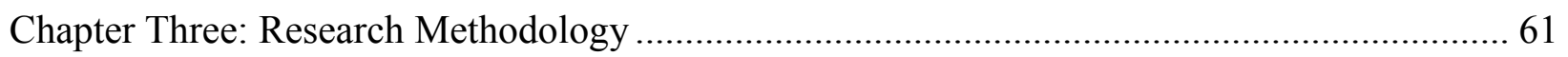

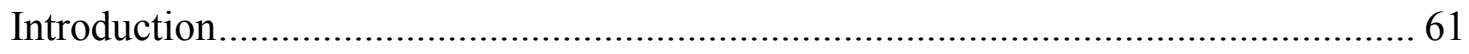

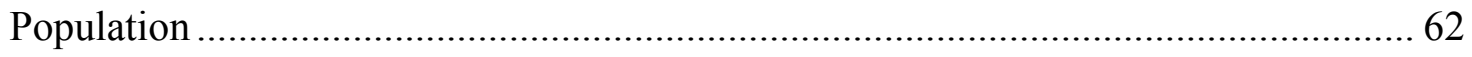

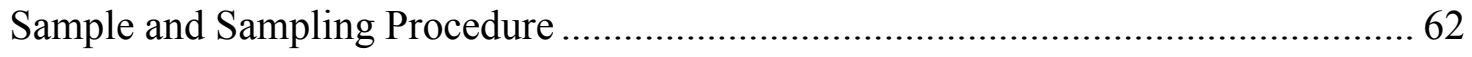

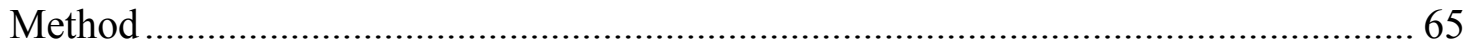

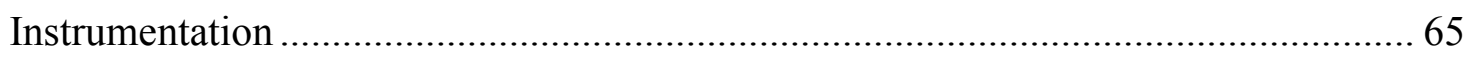

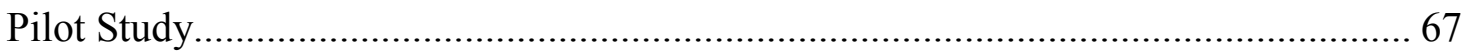




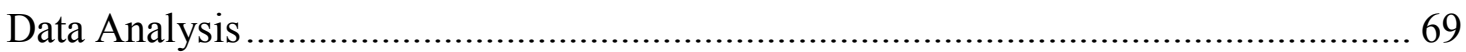

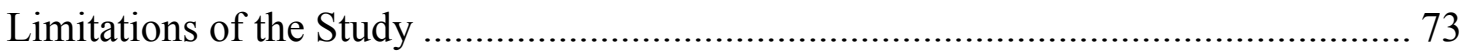

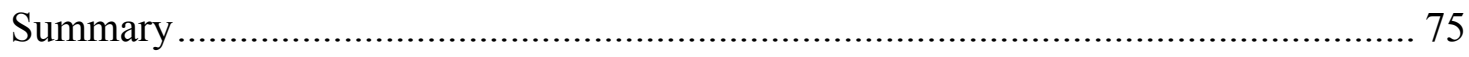

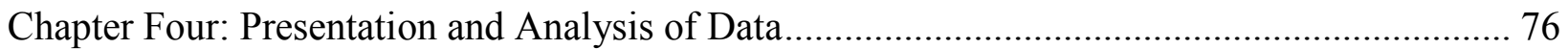

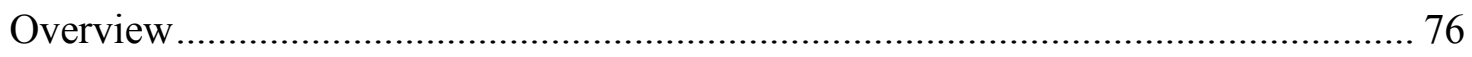

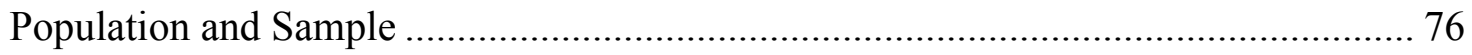

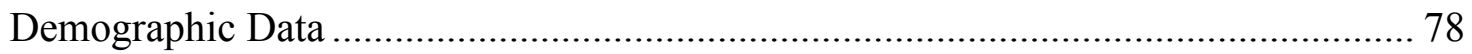

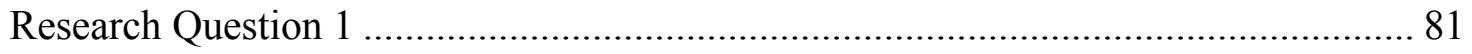

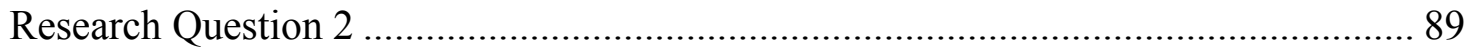

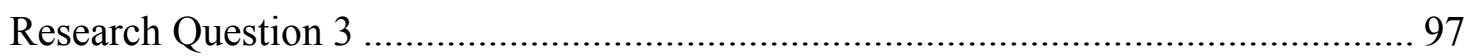

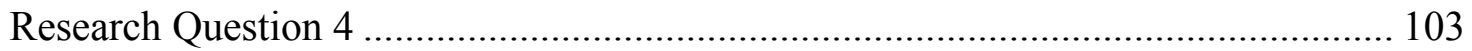

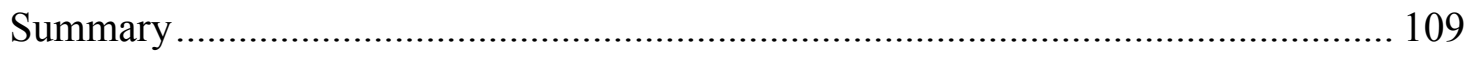

Chapter Five: Summary, Conclusions, and Recommendations................................................ 112

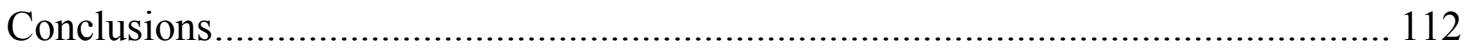

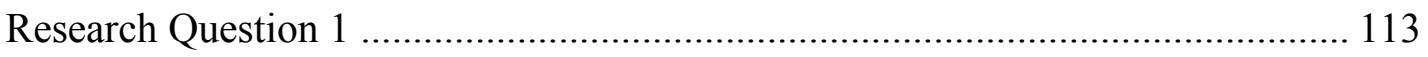

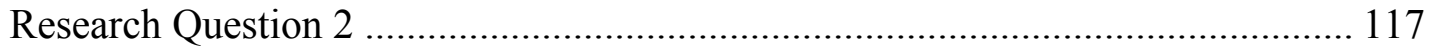

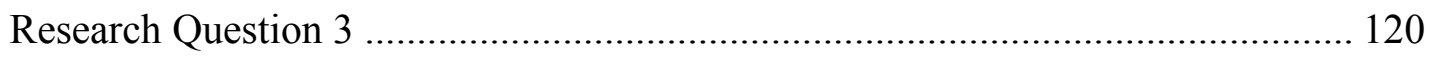

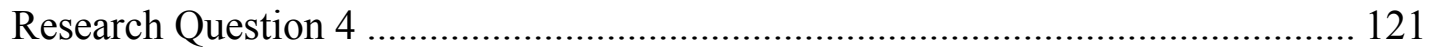

Additional Analysis ..................................................................................... 122

Recommendations for Practice ........................................................................ 123

Recommendations for Further Research................................................................ 124

Concluding Thoughts...................................................................................... 125

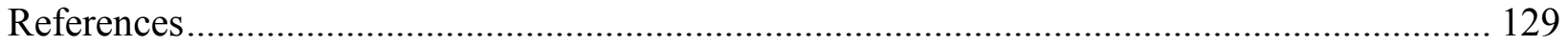




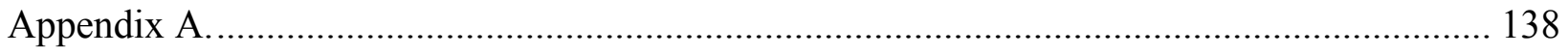

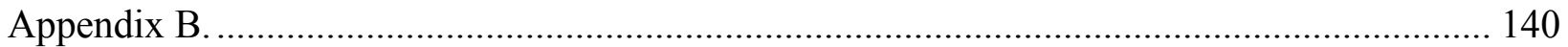

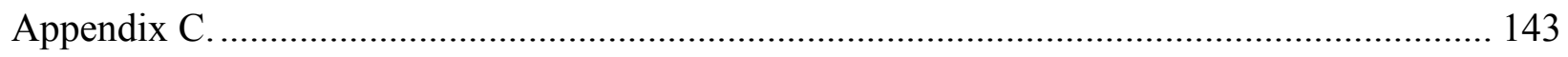

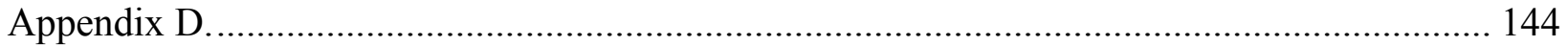

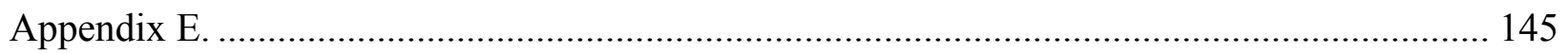

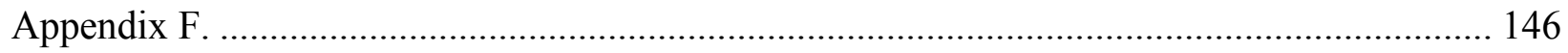

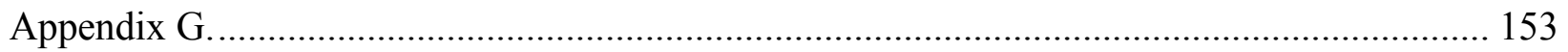

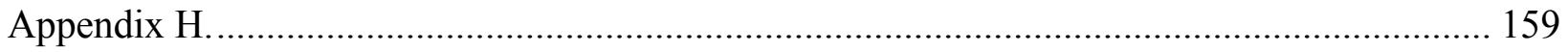




\section{Tables}

Table 1: Point Range for Each Survey Item and Dependent Variable Category.................66

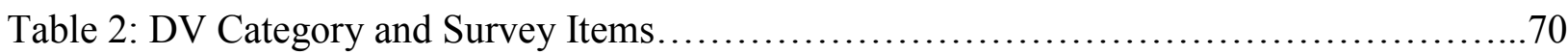

Table 3: Research Questions and Statistical Tests..................................... 73

Table 4: Breakdown of participants by school....................................... 77

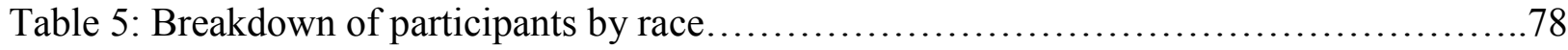

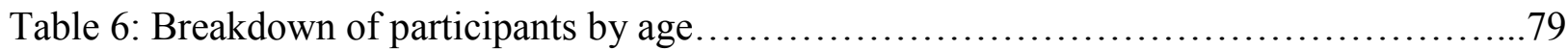

Table 7: Breakdown of participants by gender...................................... 79

Table 8: ANOVA results for each dependent variable for RQ1 ...........................82

Table 9: ANOVA results for each survey statement regarding RQ1 $\ldots \ldots \ldots \ldots \ldots \ldots \ldots \ldots \ldots . \ldots 84$

Table 10: Cumulative averages of survey statements where groups do not differ by principle for

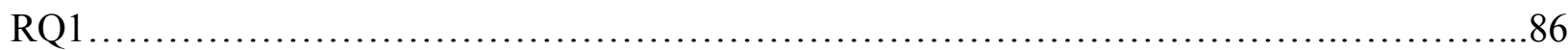

Table 11: Mean scores on statements where groups did not differ for RQ1 .................87

Table 12: ANOVA results for each dependent variable for RQ2 ..........................90

Table 13: ANOVA results for each survey statement where groups differed regarding

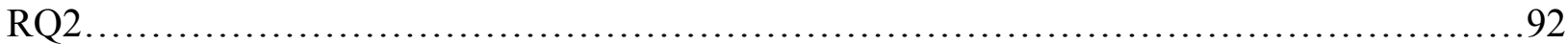

Table 14: Cumulative averages on survey statements where instructors do not differ by principle

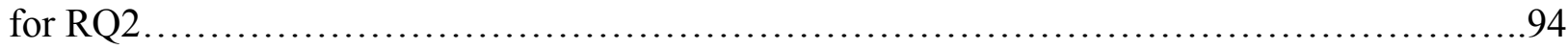

Table 15: Mean scores on statements where groups did not differ for RQ2 ..................95

Table 16: ANOVA results for each dependent variable for RQ3 ..........................98

Table 17: ANOVA results for each survey statement regarding RQ3 $\ldots \ldots \ldots \ldots \ldots \ldots \ldots \ldots \ldots 100$

Table 18: ANOVA results for each dv where groups differed for RQ4 .....................104

Table 19: ANOVA results for each survey statement regarding RQ4 .......................105 
Table 20: Cumulative averages on survey statements where instructors do not differ by principle 106

Table 21: Breakdown of statements where instructors do not differ for RQ4....

Table 22: Principles where groups had highest averages and significant differences were present

Table 23: Principle 2 statements where groups differed and centralized group had highest averages

Table 24: Principle 6 statements where groups differed and decentralized group had highest averages

Table 25: Principle 5 statements where groups differed and decentralized group had highest averages

Table 26: Principle 3 statements where groups differed and decentralized group had highest averages

Table 27: Principle 1 statements where groups differed and decentralized group had highest

averages.

Table 28: Statements where groups differ and did not differ for Principles 2 and 3

Table 29: Principles where groups had highest averages and significant differences were

present

Table 30: Comparison of current study to findings from Braxton et al. (1998)....

Table 31: Combined averages of groups regarding lowest averages where they did not differ. 


\section{Chapter One:}

\section{Introduction of the Study}

\section{Background}

Over the last 40 years, developmental education programs have become an established component of higher education in the United States. The National Center for Education Statistics (NCES, 2003) reported that in the year 2000, over $76 \%$ of institutions of higher education offered “... at least one remedial reading, writing, or mathematics course” (p. 7). NCES (2003) also reported that in the year 2000, $28 \%$ of "entering freshmen" enrolled in one remedial course (p.17). Ninety-eight percent of public two-year colleges throughout the United States offered developmental education classes as compared to $80 \%$ of four-year colleges (NCES, 2003). At the same time, $59 \%$ of private four-year colleges offered at least one class in remedial reading, writing, and/or mathematics (NCES, 2003).

Public two-year colleges are at the forefront when it comes to developmental education; these colleges are more likely to offer developmental education courses, offer more of a variety of courses, and have students who spend a significantly longer amount of time in remedial courses when compared to four-year public and private institutions (NCES, 2003). Forty-two percent of the freshmen who entered public two-year colleges in 2000 were required to attend one type of developmental course or another, whereas only 12 to $24 \%$ of the students who entered universities and four-year public colleges attended developmental courses (NCES, 2003). A greater proportion of public two-year colleges offer developmental mathematics, reading, and writing courses than do other colleges. In the year 2000, developmental reading courses were offered in $96 \%$ of public two-year colleges as compared to $49 \%$ in four-year public colleges; developmental writing courses were offered in $96 \%$ of public two-year colleges as compared to 
$67 \%$ of four-year public colleges; and developmental mathematics courses were offered in $97 \%$ of public two-year colleges as compared to $78 \%$ of four-year public colleges (NCES, 2003).

As the number of developmental courses has increased in institutions of higher education, so too has the debate over the financial burden that developmental education places on colleges, universities, and taxpayers within the United States. Researchers report that remedial education costs public universities and colleges over $\$ 1$ billion dollars per year (Breneman \& Haarlow, 1998; Kolajo, 2004; Phipps, 1998; Spann, 2000). Many opponents of developmental education regard developmental education as a redundancy in the public education process and view its presence within four-year colleges and universities as detrimental to the high educational standards required in these institutions (Breneman \& Haarlow, 1998; Hoyt \& Sorenson 2001; Ignash 1997; Jehangir, 2002; Kolajo, 2004; Kozeracki 2002; NCES, 2003; Phipps, 1998; Spann, 2000). For example, in 1998 the City University of New York led the way in addressing the issue of developmental education and higher education standards by eliminating developmental education courses at the university level (Breneman \& Haarlow, 1998; NCES, 2003). Many opponents argue that developmental education courses should be limited to two-year colleges (Crowe, 1998; Ignash, 1997; McCabe, 2000; NCES, 2003; Phelan, 2000; Roueche \& Roueche, 1999; Spann, 2000).

Proponents of developmental education courses argue that the financial debate over these courses is incomplete without considering the return on the investment in human capitol. Breneman et al. (1998) stated that "[t]otal economic costs would include costs borne by students through foregone earnings and diminished labor productivity and by society as a whole through a failure to develop fully the nation's human capitol" (p. 2). Phipps (1998) argued that the investment in developmental education is a "...more cost effective investment when considering 
the alternatives..." of unemployment and low-wage jobs (p. 8). Kolajo (2004) pointed out that the cost for developmental education courses is potentially offset by the income differentiation between an individual who graduates from college and one who does not. The individual who enters the workforce with a four-year degree may have a potential impact on the number of tax dollars generated on both the federal and state levels. Kolajo (2004) noted that if just one out of every three developmental education students were to graduate from college they would have the potential to add over $\$ 70$ billion in federal tax dollars and over $\$ 13$ billion in state tax dollars.

Some researchers argue that developmental education courses can act as an entry point to post-secondary education for a diversity of students (Jehangir, 2002; Levin, 2001; McCabe, 2000; NCES, 2008; Roueche, Roueche \& Ely, 2001). Many of the students who attend developmental courses are adult, nontraditional, at-risk, and/or minority students (Jehangir, 2002; Kolajo, 2004; NCES, 2008; Phipps, 1998). Roueche, Roueche, and Ely (2001) summed up student demographics in developmental education courses with the following statement: ...the demographics of existing developmental education programs mirror the hanging demographics of the nation's population, including increasing numbers of single parents and children of single-parent families, high school dropouts seeking to complete their education, workers requiring technical retraining, new immigrants, and other groups of skill-deficient students. (p. 520)

Jehangir (2002) stated that developmental education also offers a point of entry for students with disabilities; citing the United States Department of Education (1995), the author (Jehangir, 2002) pointed out that the number of students with disabilities attending institutions of higher education increased "over 200\%" between 1977 and 1994 (p. 21). 


\section{Statement of the Problem}

Decentralized and centralized models are the two organizational models used predominately by both two- and four-year institutions to administer developmental education courses (Boylan, 2002; Boylan, Bliss, \& Bonham, 1997; Gerlaugh, Thompson, Boylan, \& Davis, 2007; Kozeracki \& Brooks, 2006; NCES, 2003; Perin, 2002). Decentralized (or mainstreamed) developmental education programs integrate developmental/remedial courses into regular college departments (Boylan, 2002; Boylan, Bliss, \& Bonham, 1997; Gerlaugh, Thompson, Boylan, \& Davis, 2007; Kozeracki \& Brooks, 2006; Perin, 2002). In decentralized programs, students who are required to attend developmental education courses attend those courses within the respective course department where the course is taught by regular department faculty. If a student is required to take developmental English or math, then he or she participates in a remedial English or math course that is housed within the regular English or mathematics department. Centralized models house their developmental courses within a developmental education department, a department independent from the regular college English or mathematics departments (Boylan, 2002; Boylan, Bliss, \& Bonham, 1997; Gerlaugh, Thompson, Boylan, \& Davis, 2007; Kozeracki \& Brooks, 2006; Perin, 2002). In centralized programs, remedial reading, math, and English courses are offered by faculty who are a part of the developmental education program and whose focuses are primarily on providing remediation to academically underprepared students.

Some developmental education scholars argue that centralized developmental education courses are more effective than decentralized developmental education courses when it comes to student success (Boylan, 2002; Boylan, Bliss, \& Bonham, 1997; Carter, Hashway, \& SandefordLyons, 1999; Gerlaugh, Thompson, Boylan, \& Davis, 2007; Kozeracki \& Brooks, 2006). Boylan et al. (1997) found that students attending centralized developmental education courses in twoyear colleges were less likely to drop-out than were students in decentralized courses. Students 
attending centralized developmental education courses in four-year colleges had higher “...firstterm GPAs and higher cumulative GPAs than those participating in decentralized programs" (Boylan et al., 1997, p. 4). Boylan et al. (1997) found that "[s]tudents participating in centralized programs were also more likely to pass developmental courses in English at 2-year institutions and in mathematics at 4-year institutions" (p. 4).

Perin (2002) argued that the research is inconclusive in terms of determining the effectiveness of centralized and decentralized programs when it comes to student success. Perin (2002) argued that both program models may offer effective components in regard to promoting student success. For instance, Perin (2002) stated that centralized programs may offer more ancillary support services and teachers who are more motivated and have more experience working with underprepared students, whereas the quality of instruction in decentralized developmental education courses may align better with the regular college curriculum, providing students with an advantage when entering into regular college courses. Perin (2002) stated that decentralized developmental courses may also “...provide opportunities for academically underprepared students to interact with their higher achieving peers and participate more fully in college life," thus making the integration into regular college courses for these students an easier process (p. 3). McCabe (2000) suggested that one difference between decentralized and centralized developmental programs may occur within the affective domain with regard to developmental students. McCabe (2000) argued that by allowing developmental students to be integrated into the college environment through decentralized programs there may be a less negative effect on student attitudes and expectations; students who receive remediation within a regular college department may be more prepared for the challenges of regular college courses because they know what to expect within the regular academic department. 
Although there remains some division over which organizational model of developmental education is most effective in regard to student success, researchers have identified and generally agree on many of the specific learner-centered practices needed to make developmental education programs more effective. For example, Smittle (2003) outlined six principles that instructors should adopt when working in developmental education programs:

- Commit to teaching underprepared students

- Demonstrate good command of the subject matter and the ability to teach a diverse student population

- Address noncognitive issues that affect learning

- Provide open and responsive learning environments

- Communicate high standards

- Engage in ongoing evaluation and professional development (pp. 11-14)

The work of Chickering and Gamson (1987) has also been used by developmental education educators when evaluating best practices in the classroom (Smittle, 2003). Chickering, Gamson, and Barsi's survey (1989), 7 Principles for Good Practice in Undergraduate Education, has become a standard self-assessment tool for instructors in higher education. These principles for good practice include encouraging student/faculty contact, encouraging cooperation among students, encouraging active learning, providing prompt feedback, emphasizing time on task, communicating high expectations, and respecting diverse talents and ways of learning. In short, Chickering and Gamson's (1987) principles are considered learner-centered. The good practice principles are highly regarded by a variety of scholars and provide the basic standards deemed by many as the cornerstones for improving not only the quality of undergraduate education but the educational experiences of developmental students as well. Citing the work of various scholars, 
Pascarella, Cruce, Umbach, Wolniak, Kuh, Carini, Hayek, Gonyea, Zhao (2006) noted the following:

The influence of Chickering and Gamson's seven principles has been extensive...the NSSE, one of the most broad-based annual surveys of undergraduates in the country, is based on que stionnaire items that attempt to operationalize the seven good practices. (p. 254)

One question that remains unanswered about centralized and decentralized developmental education programs is whether there is a difference in the degree to which either program uses practices that are learner-centered. An analysis of the use of learner-centered principles within centralized and decentralized developmental education courses can provide more knowledge about these two particular program models. Ultimately, there is a need for further analysis of both centralized and decentralized developmental education programs to determine if differences exist between them in regard to principles for effective teaching and/or learner-centered practices.

In order to overcome the pressures brought on by legislators, tax payers, and businesses, developmental education programs will be required to ensure the use of best practices for their students. New information about how centralized and decentralized developmental education programs utilize learner-centered practices will be useful for administrators, heads of departments, and instructors when making decisions about how best to develop and organize effective developmental education programs. The research proposed here will provide some insight into the differences between centralized and decentralized developmental education programs in regard to their levels of learner-centeredness in four public Appalachian community colleges. 


\section{The Purpose of the Study}

The purpose of this research was to examine students' and instructors' perceptions regarding learner-centered teaching practices in six Appalachian community colleges. Data were collected using an adjusted version of Chickering, Gamson, and Barsi's (1989) seven principles inventory. These seven principles are regarded as learner-centered practices. Research Question 1 utilized only four of the community colleges and examined the relationship between centralized and decentralized course-delivery types and students' perceptions of these learnercentered practices being used within the classroom. The researcher surveyed students attending English/writing and mathematics courses in centralized and decentralized developmental education courses to determine if there were significant differences in their perceptions regarding the principles for good practice; at the same time, the researcher surveyed students and instructors in all six of the public Appalachian community colleges sampled to determine if differences existed between developmental education instructors' perceptions and developmental students' perceptions in regard to each of the seven principles. Furthermore, this research used these six schools to attempt to determine if there were significant differences in the perceptions of students attending developmental English/writing courses and students attending developmental mathematics courses in regard to each of the seven principles. Finally, this research used these six schools to determine if there were significant differences in instructor practices regarding the seven principles for good practice based on each course discipline taught (i.e. English/writing vs. mathematics). 


\section{Research Question 1}

RQ1. Are there statistically significant differences between the perceptions of students attending centralized developmental education courses and students attending decentralized developmental education courses regarding the 7 Principles for Good Practice in Undergraduate Education?

a. Is there a statistically significant difference between the perceptions of students attending centralized developmental education courses and students attending decentralized developmental education courses regarding the extent of active learning within the classroom?

b. Is there a statistically significant difference between the perceptions of students attending centralized developmental education courses and students attending decentralized developmental education courses regarding the extent of contact between students and faculty?

c. Is there a statistically significant difference between the perceptions of students attending centralized developmental education courses and students attending decentralized developmental education courses regarding the extent of cooperation encouraged among students within the classroom?

d. Is there a statistically significant difference between the perceptions of students attending centralized developmental education courses and students attending decentralized developmental education courses perceptions regarding the extent of feedback provided in the classroom?

e. Is there a statistically significant difference between the perceptions of students attending centralized developmental education courses and students attending decentralized 
developmental education courses in regard to the extent that time on task activities are emphasized within the classroom?

f. Is there a statistically significant difference between the perceptions of students attending centralized developmental education courses and students attending decentralized developmental education courses regarding the extent that high expectations are communicated within the classroom?

g. Is there a statistically significant difference between the perceptions of students attending centralized developmental education courses and students attending decentralized developmental education courses regarding the extent that diverse talents and ways of learning are respected within the classroom?

\section{Research Question 2}

RQ2. Are there statistically significant differences between Developmental Education instructors' perceptions and students' perceptions regarding the 7 Principles for Good Practice in Undergraduate Education?

a. Is there a statistically significant difference between developmental education instructors' perceptions and students' perceptions regarding the extent of active learning within the classroom?

b. Is there a statistically significant difference between developmental education instructors' perceptions and students' perceptions regarding the extent of contact between students and faculty?

c. Is there a statistically significant difference between developmental education instructors' perceptions and students' perceptions regarding the extent of cooperation encouraged among students within the classroom? 
d. Is there a statistically significant difference between developmental education instructors' perceptions and students' perceptions regarding the extent of feedback provided in the classroom?

e. Is there a statistically significant difference between developmental education instructors' perceptions and students' perceptions regarding the extent that time on task activities are emphasized within the classroom?

f. Is there a statistically significant difference between developmental education instructors' perceptions and students' perceptions regarding the extent that high expectations are communicated within the classroom?

g. Is there a statistically significant difference between developmental education instructors' perceptions and students' perceptions regarding the extent that diverse talents and ways of learning are respected within the classroom?

\section{Research Question 3}

RQ3. Are there statistically significant differences between developmental math students' perceptions and developmental English/writing students' perceptions in regard to the 7 Principles for Good Practice in Undergraduate Education?

a. Is there a statistically significant difference between the perceptions of students attending developmental math courses and students attending developmental English/writing courses regarding the extent of active learning within the classroom?

b. Is there a statistically significant difference between the perceptions of students attending developmental math courses and students attending developmental English/writing courses regarding the extent of contact between students and faculty? 
c. Is there a statistically significant difference between the perceptions of students attending developmental math courses and students attending developmental English/writing courses regarding the extent of cooperation encouraged among students within the classroom?

d. Is there a statistically significant difference between the perceptions of students attending developmental math courses and students attending developmental English/writing courses regarding the extent of feedback provided in the classroom?

e. Is there a statistically significant difference between the perceptions of students attending developmental math courses and students attending developmental English/writing courses in regard to the extent that time on task activities are emphasized within the classroom?

f. Is there a statistically significant difference between the perceptions of students attending developmental math courses and students attending developmental English/writing courses regarding the extent that high expectations are communicated within the classroom?

g. Is there a statistically significant difference between the perceptions of students attending developmental math courses and students attending developmental English/writing courses regarding the extent that diverse talents and ways of learning are respected within the classroom?

\section{Research Question 4}

RQ4. Are there statistically significant differences between the perceptions of instructors teaching in developmental English/writing courses and instructors teaching in developmental 
mathematics courses regarding their use of the 7 Principles for Good Practice in Undergraduate Education?

a. Is there a statistically significant difference between the perceptions of instructors teaching in English/writing developmental education courses and instructors teaching in mathematics developmental education courses regarding the extent of active learning within their courses?

b. Is there a statistically significant difference between the perceptions of instructors teaching in English/writing developmental education courses and instructors teaching in mathematics developmental education courses regarding the extent of contact between students and faculty?

c. Is there a statistically significant difference between the perceptions of instructors teaching in English/writing developmental education courses and instructors teaching in mathematics developmental education courses regarding the extent of cooperation encouraged among students within their courses?

d. Is there a statistically significant difference between the perceptions of instructors teaching in English/writing developmental education courses and instructors teaching in mathematics developmental education courses regarding the extent of feedback provided in their courses?

e. Is there a statistically significant difference between the perceptions of instructors teaching in English/writing developmental education courses and instructors teaching in mathematics developmental education courses in regard to the extent that time on task activities are emphasized within their courses? 
f. Is there a statistically significant difference between the perceptions of instructors teaching in English/writing developmental education courses and instructors teaching in mathematics developmental education courses regarding the extent that high expectations are communicated within their courses?

g. Is there a statistically significant difference between the perceptions of instructors teaching in English/writing developmental education courses and instructors teaching in mathematics developmental education courses regarding the extent that diverse talents and ways of learning are respected within their courses?

\section{Significance of the Study}

Overall, this study provides an analysis of students' and instructors' perceptions in regard to teaching practices in six community colleges. At the same time, this study provides insight into the organizational structures used by four of these six Appalachian community colleges to deliver developmental education courses and the differences between the perceptions of students who attended those courses. Various researchers suggest that teaching practices within developmental education classrooms are the most important determiners of success for the students who attend those courses (Boylan et al., 1997; Kozeracki, 2005; Perin 2005; Perin, 2002; Smittle, 2003). Kozeracki (2005) noted that “[c]ommunity college instructors' abilities to respond to the needs of their students depends on the knowledge, training and experience they bring to the classroom" (p. 39). The question has been posed whether or not there are statistically significant differences in teacher practices between instructors in centralized and decentralized developmental education programs. Many researchers argue that the organizational structure of these programs is consequential to their quality and the subsequent success of their students (Boylan et al., 1997; Perin, 2005; Perin, 2002). Some researchers argue that centralized 
developmental education programs are more effective because instructors are hired for the specific purpose of "...teaching basic precollege academic skills, and because counseling and ancillary tutoring are more readily available" (Perin, 2005, p. 28). This study identified differences that existed in the perceptions of students attending centralized and decentralized developmental education programs in regard to the teaching practices outlined in Chickering and Gamson's (1987) principles for good practice in undergraduate education; it also identified the differences in perceptions of students and instructors based on teaching disciplines.

There are several implications possible from this research. Although this research characterized each sample institution, including descriptive information about participants, it was more concerned with identifying the differences in teacher practices between the proposed organizational structures and differences perceived by students and instructors based on subject area (i.e., math versus English). This research found that there were statistically significant differences between groups in all four research questions. Ultimately, these findings provide the schools involved with greater insight into how students perceived teaching practices occurring within their developmental education courses. At the same time, this research provides a pathway for further research into the organizational structures used by community colleges to offer developmental education coursework and a gateway to further study regarding the differences in the perceptions of students and instructors. The knowledge generated through this study may prompt further research in an attempt to generalize the differences between centralized and decentralized developmental education programs throughout the entire Appalachian region or throughout the United States. This research hopefully adds to the body of knowledge that has been developing about developmental education over the last few decades. Because the latest major research study regarding developmental education was conducted in the 
year 2000 and published in 2003 by the National Center for Education Statistics, there is a need to continue to update the examination of developmental education programming. This current study is important to help continue the focus on improving practices in developmental education programs and courses throughout higher education.

\section{Definition of Terms}

1. Appalachia: "[A] 200,000-square-mile region that follows the spine of the Appalachian Mountains from southern New York to northern Mississippi. It includes all of West Virginia and parts of 12 other states: Alabama, Georgia, Kentucky, Maryland, Mississippi, New York, North Carolina, Ohio, Pennsylvania, South Carolina, Tennessee, and Virginia. About 23 million people live in the 410 counties of the Appalachian Region ...” (Appalachian Regional Commission Web Site).

2. Appalachian Community College: For this study an Appalachian community college is defined as a public community college that is located in and predominately serves residents of the Appalachian region of the United States.

3. Assessment: the systematic collection, review, and use of information to improve student learning.

4. At-Risk College Student: For this study the at-risk college student is any student who has one or more entry characteristics that may increase his or her potential for noncompletion of his or her post-secondary education program. These characteristics include, but are not limited to first-generation, nontraditional, socioeconomic status, etc.

5. Centralized Developmental Education Program: Developmental education programs that offer remedial and/or noncredit courses in an organized, independent department with centralized control; these courses are not generally offered as a part of the regular 
academic department but are their own department within a particular institution of higher education (Boylan, Bliss, Bonham, 1997; Perin, 2002).

6. Decentralized Developmental Education Program: Developmental education programs that offer remedial and/or noncredit courses in regular academic departments with very little centralized coordination; these courses are often referred to as "stand alone" courses or “mainstreamed” courses (Boylan, Bliss, Bonham, 1997; Perin, 2002).

7. Dependent Variable: for this study the dependent variables are the seven principles of good practice, which include encouraging student/faculty contact, encouraging cooperation among students, encouraging active learning, providing prompt feedback, emphasizing time on task, communicating high expectations, and respecting diverse talents and ways of learning.

8. Developmental Education: "Developmental education refers to a broad range of courses and services organized and delivered in an effort to help retain students and ensure the successful completion of their post-secondary education goals. Furthermore, these courses and services are generally delivered according to the principles and theories of adult development and learning, hence the term 'developmental' education" (Boylan \& Bonham, 2007).

9. First-Generation College Student: A student who attends post-secondary education as the first person to do so in his or her immediate family. This individual's parents have not completed a four-year degree (U.S. Department of Education).

10. Independent Variables: for this study, the primary independent variable will be the organizational model used by each public community college to deliver developmental courses (i.e., centralized or decentralized) 
11. Learner-Centered Classroom: A classroom environment led by an instructor who designs his or her courses utilizing the principles found in learner-centered practices.

12. Learner-Centered Practices: Various teaching practices that are focused on the process of learning or how students learn.

13. Learning Support Services: For this study learning support services are ancillary services provided by a particular institution of higher education to help supplement instruction through tutoring and mentoring; these services also include compensatory training in learning strategies and study skills, etc.

14. Non-Traditional College Student: A first-time college student who begins college and is twenty-five years of age or older. Many times these students begin school as part-time or full-time students and have additional life responsibilities working or taking care of families (Benshoff \& Lewis, 1992; Cross, 1980).

15. Remedial Education: any course used to "remedy" a student's deficiencies in a particular academic area. Most often remedial education is offered in mathematics, English, and/or reading. As a term, remedial education is often used synonymously with developmental education; however, several researchers point out that there are fundamental differences between remedial education and developmental education, whereby developmental education utilizes the principles of student development and helping the "whole" student develop. Where remedial educational practices focus primarily on academics, developmental education focuses on "noncognitive factors" as well (Higbee, Arendale \& Lundell, 2005).

16. Student-Centered Institution: Any institution of higher education that adopts and adheres to principles designed to focus on the successful development of the post-secondary 
student. These principles include the use of learner-centered practices, including institutional-wide active learning and assessment practices, as well as designing extracurricular activities that focus on intellectual, cognitive, and personal development.

17. Traditional College Student: For this study, the traditional college student is any student who begins post-secondary education after graduating from high school before his or her twenty-fifth birthday.

\section{Summary}

The first chapter of this study provides the rationale for the remaining chapters of this research project. The goal for this research is to analyze and compare the centralized and decentralized organizational models found in four public Appalachian community colleges' developmental education programs to determine if differences exist in teaching practices. Chapter One provides a basic introduction of the research problem and the specific research questions to be addressed. Chapter Two of this study provides a review of pertinent literature regarding organizational theory, developmental education, Chickering and Gamson's (1987) principles for good practice, and the effects of centralization and decentralization on student outcomes in developmental education courses. This chapter begins by providing an overview of organizational theories pertaining to educational institutions in the United States and then moves on to highlight the conceptualization used to frame this research, including an overview of the history of remedial and developmental education in post-secondary education. The final sections of Chapter Two examine specific concepts associated with best practices, including an overview of the development and research involving Chickering and Gamson's (1987) principles for good practice before ending with an examination of some of the research pertaining to centralized and decentralized developmental education courses and student outcomes. 
Chapter Three of this study provides a detailed description and framework of the research model employed in this study. This chapter details the population, the sample, sampling procedures, instruments used to collect data, data analysis techniques, and the limitations of the study.

Chapter Four of this study presents the findings. This chapter provides a detailed statistical analysis of the data and provides insight into the differences between the sample populations. The statistical analysis performed in this chapter describes the sample populations in terms of the guiding research questions to determine statistical findings.

Chapter Five provides a summary of the results of this study. This section details the implications of the results of this study and provides suggestions regarding the findings and provides recommendations for further research. 


\section{Chapter Two:}

\section{Review of the literature}

\section{Overview}

Chapter Two examines a wide body of literature relevant to the general principles of organizational structure, developmental education programs and theories in student development, Chickering and Gamson's (1987) work developing the principles for good practice in undergraduate education, and organizational structure and student outcomes. The first section of this chapter examines some of the conventional theories of organizational structure and attempts to introduce a framework for the study by providing a general description of institutions of higher education. The second part of this chapter examines the growth of developmental education programs, highlighting the historical growth of developmental education and relevant theories in student development that have been consequential for students, scholars, instructors, administrators, and organizations. Part three of this chapter examines closely the work of Chickering and Gamson (1987) and attempts to provide a detailed description of the authors' development of and work with the principles for good practice in undergraduate education. Part four of this chapter examines organizational structure as an independent variable and attempts to highlight existing research that focuses on the relationship between organizational structure and organizational effectiveness, including the effects of centralization and decentralization of developmental education courses on student outcomes; this section also provides research regarding differences between soft paradigmatic and hard paradigmatic disciplines. The final section of this chapter provides a summary and endeavors to unify previous research and conceptualizations with the processes of the current investigation. 


\section{Organizational Theory}

Over time various conceptualizations of organizations have evolved. Scholars have depicted colleges and universities as everything from rationally organized institutions defined by their bureaucratic structures to organized anarchies convoluted by ambiguity (Cohen, March, \& Olsen, 1972; Farazmand, 2002; Fuller, Wood, Rapoport, \& Dornbusch, 1982; Hammond, 2004; Kuh, 2003; Marion, 2002; Peterson, 1985; Weick, 1976). Farazmand (2002) provided an exhaustive list of organizational theories detailing the progression of organizational studies over the last century. In his book, Modern Organizations: Theory and Practice, Farazmand (2002) categorized early theories of organization with the following statement:

...the entire spectrum of [early] theories may fall under the three broad categories of instrumental rationality of the classical and neoclassical traditions, the systems theory and its variants pointing to the broader concepts of organization with their rational and environmental determinism, and the critical and interpretive theories with their main focus on pr ocesses and change-orientation leading to improvements in human life entangled by organizational rationality of modern capitalism and bureaucratic order. (p. 49)

Within the aforementioned categories, Farazmand (2002) listed formal theories that include scientific management, principles of management, principles of administration, and ideal-type bureaucracy. Farazmand (2002) also included human relations theories of organization, contemporary organizational theories, decision and behavioral theories, systems theory, contingency theory, population ecology theory, resource-dependence model, market theory, transaction-cost theory, agency theory, organizational humanism as well as a variety of critical and interpretive theories of organization. In his chapter on emergent theories of organization, Farazmand (2002) noted that "[n] ew paradigms are emerging which suggest 
alternative models of organization" (p. 63). These theories include the garbage can model, natural selection theory, institutional theories of organization, and chaos and transformation theories. In their book, Reframing Organizations: Artistry, Choice, and Leadership, Bolman and Deal (2003) provided four frames with which to view organizations in general, including the structural frame, the political frame, the human resource frame, and the symbolic frame. Bolman et al. (2003) highlighted a variety of organizational theories, including Mintzberg's (1979) five forms of organizational structure: simple structure, machine bureaucracy, professional bureaucracy, divisionalized form, and adhocracy. Peterson (1985) organized a number of postsecondary organizational theories into five categories:

- Internal and purposive (i.e., formal-rational/goal oriented; collegial/professional community; political/public bureaucracy)

- Environmental (i.e., open systems; contingency; strategic; life cycle)

- Technology (i.e., task/techno-structure; information system/resources model)

- Emergent Social Systems (i.e., Temporary adaptive; organized anarchy; loosely coupled; social networks; organizational culture/values; organizational learning; natural/antimodels)

- Interorganizational (i.e., systems of organizations; organizational networks; ecology models; industry model) (p. 7)

Most scholars categorize organizational theories into open or closed types (Cohen, March, \& Olsen, 1972; Farazmand, 2002; Fuller, Wood, Rapoport, \& Dornbusch, 1982; Hammond, 2004; Kuh, 2003; Marion, 2002; Peterson, 1985; Weick, 1976). In his book, Leadership in Education: Organizational Theory for the Practitioner, Marion (2002) categorized organizational systems into closed, open, and anti-positivist systems. Marion (2002) noted that 
closed-type organizational theories include scientific management, bureaucracy, administration theory, human relations, and structuralism theory. Marion (2002) categorized contingency theory as an open system; anti-positivist theories include strategic choice, population ecology, culture theory, critical theory, institutionalism, and complexity theory.

\section{Closed Systems}

Marion (2002) described closed systems as highly generalizable macrotheories. Most scholars note that the focus of closed theories of organization is on the efficiency and effectiveness of productivity (Farazmand, 2002; Marion, 2002; Peterson, 1985). Marion (2002) argued that closed theories operate on the assumption that outcomes are reached through the implementation of “...definable and rational efficiency/effectiveness strategies...” (p.1). Farazmand (2002) noted that "[s]tability and internal rationality are the central features of a closed system" (p. 31). Bureaucratic systems, machine theories, and human resource theories are described as closed systems because of their self-contained systems used for managing productivity. For instance, rational-bureaucracies might utilize divisions of labor to segment and manage tasks in order to improve the effectiveness of the overall organization. Human resource type organizations develop policies and activities that enhance and meet the needs of workers in order to improve productivity. The major assumption about closed systems is that these organizations are “...untainted by external forces or issues...” (Marion, 2002, p. 2). It is assumed that the internal policies, procedures, and structures used by these organizations are all that is needed to improve the outcomes produced by these agencies. Marion (2002) stated that The Closed System mindset pervaded the worldview of the society that developed the structure and rationale of $20^{\text {th }}$-century public education; thus it was inevitable 
that Closed System assumptions would influence that development and would be evident in its structure even today. (p. 2)

\section{Open System}

Open systems are defined by their openness to the environment. Where closed systems utilize internal processes to increase productivity and, ultimately, cope with environmental forces, the open system of organization “... seeks solutions to problems within a broad range of organizational and environmental dynamics" (Marion, 2002, p. 87). Marion (2002) pointed out that open system theorists define these systems through the claim that "...organizational structure and behavior are significantly influenced by their environments" (p. 86). Scholars note that open systems are devised of subsystems that seek to maintain equilibrium based on a feedback system between the organization and the environment (Farazmand, 2002; Marion, 2002). Open systems differ significantly from closed systems because of their ability to adapt to external changes (Farazmand, 2002; Marion, 2002).

\section{Anti-positivist Systems}

Marion (2002) regarded anti-positivist systems as the "...third shift in organizational thought within the $20^{\text {th }}$ and $21^{\text {st }}$ centuries" (p. 165). As Marion (2002) acknowledged, these theories find their commonality in “...their anti-positivistic philosophy” (p. 165). Marion (2002) listed the following points as the defining characteristics of anti-positivist systems:

- Anti-positivism is idiographic, meaning that organizations are understood within the context of their individual, unique situations. Every organization has a unique set of needs.

- The research methodology is often nonpositivist and qualitative, although the empirical methods have been used effectively by these theorists. 
- The theory explains organizational structure by non-material factors such as ideas, ideologies, perceptions, and norms.

- The theory is nondeterminist in that managers are seen as having considerable discretion regarding structure and management style.

- Theory is closely informed by qualitative research and armchair speculation; there is limited, if any, hypothesizing prior to data collection. It is not necessarily built on data patterns and arguments of earlier works.

- The theory is consciously nonscientific; the aim is to understand local conditions rather than to make generalizations. (p. 165)

The following sections will examine some of the prominent organizational theories that influence the way researchers and scholars view organizations of higher education in general. Although the review here provides a general survey of each of these theories, the goal is to provide insight into some of the more prominent theoretical conceptualizations that are used to better understand the study of modern educational organizations. Although this study is framed using a rational conceptualization of organization to describe institutions of higher education, each of the theories highlighted below offers additional frameworks with which to discover the complexities apparent to organizing the coursework in developmental education programs.

\section{Rational Bureaucracy}

Peterson (1985) pointed out that prior to the influx of organizational research involving colleges and universities in the 1960s and 1970s, the organizational structures of institutions of higher education were generally defined by three models: rational or goal models; collegial or professional community models; and political or public bureaucracy models. Rational theories of organization have long provided a framework for understanding the organization of colleges and 
universities. Although some organizational scholars have called for more effective theoretical frameworks to help describe and understand institutions of higher education (Bolman \& Deal, 2003; Marion, 2002; Peterson, 1985), arguing that new conceptualizations are needed to promote a better understanding of organizational efficacy, organizational outcomes, individual interactions, etc, many authors continue to utilize rational concepts to characterize the organization of post-secondary institutions (Berger, 2000; Bolman \& Deal, 2003; Kuh, 2003; Marion, 2000; Peterson, 1985).

Examining Weber's (1947) seminal work concerning bureaucratic structures, Kuh (2003) cited institutions of higher education as having seven bureaucratic characteristics, including “...hierarchy of authority with clear chains of command, limits on authority, divisions of labor, technical competence, standard operating procedures, rules for work, and differential rewards" (pp. 272-273). Hammond (2004) pointed out that a hierarchical line of authority exists in most large American research universities; these institutions have a chain-of-command structure that generally includes the president, academic vice president and/or provost, deans, and department heads or chairs. Most universities and colleges utilize a clear division of work; for example, most components and activities associated with the university's academic curriculum are concentrated under the leadership and guidance of a provost or academic vice president who presides over an office of academic affairs; this particular division of the university focuses on everything academic and can generally be further subdivided to include departments or units distinguished to provide academic support services, testing services, and learning centers as well as the academic departments (Duryea, 1973). Furthermore, the business processes of the institution are generally situated within a business division where a department head oversees the activities associated with the business processes. All of these departments can be described as subunits of 
the organization. All of these subunits follow a clear chain of command, have limits on authority, follow certain standard operating procedures, and are generally comprised of professionals who are trained to achieve specific tasks.

Scholars have gone further to differentiate institutions of higher education as professional bureaucracies (Bolman \& Deal, 2003; Cheng, 1990; Marion, 2002; Mintzberg, 1979). Marion (2002) highlighted Mintzberg's (1979) work with professional bureaucracies pinpointing that "[t]heir technologies are sufficiently stable to allow standardization of procedures...but their tasks so complex that they must be controlled directly by the operators who perform them" (p. 208). Professional bureaucracies include all the components of a bureaucratic organization but permit both standardization and decentralization and depend on the expertise and skills of professionals to operate effectively (Bolman \& Deal, 2003; Cheng, 1990; Duryea, 1973; Marion, 2002; Mintzberg, 1979). Most subunits within universities, community colleges, and four-year colleges can be described as components of a professional bureaucracy because these divisions are allotted some degree of decision making, goal setting, and resource development separate from the central governing body of the organization.

\section{Humanistic View}

The humanistic view is based largely on Abraham Maslow's research on human need (Bolman \& Deal, 2003; Farazmand, 2002; Fuller et al., 1982; Marion, 2002). Maslow, an existential psychologist, examined motivation in humans and determined that a hierarchical "five basic categories" existed in which the motivation of humans is strongly influenced (Bolman et al., 2003, p. 117). These categories of need include physiological, safety, belongingness and love, esteem, and self-actualization (Bolman et al., 2003). The adaptation of Maslow's theory on human need to develop a humanistic frame for understanding organizations can be seen as a 
direct response to the bureaucratic framework that was historically seen to dominate the view of organizations. Douglas McGregor (1960) advanced the humanistic view through the development of Theory X and Theory Y. McGregor's (1960) work highlights the debate over the intrinsic values of humans in general. Theory $\mathrm{X}$ argues that “...workers are inherently lazy, indolent, mean-spirited, and opposed to work" (Marion, 2000, p. 51). Theory Y “...sees workers as basically cooperative, caring, friendly, industrious, and responsible" (Marion, 2000, p. 51).

Fuller et al. (1982), while examining the organizational influence on individual efficacy, framed their research through humanistic models. Fuller et al. (1982) noted that " $\mathrm{t}] \mathrm{he}$ humanistic view of organizations sees hierarchical social control and routinization of work tasks as detrimental to, not supportive of, individual performance and organizational efficacy" (p. 18). Fuller et al. (1982) argued that "...this view of motivation in formal organizations has shifted the view, even within the bureaucratic model, from the manager to the lower level individual" (p. 18). Following this line of thought, Bolman and Deal (2003) provided a human resource frame of viewing organizations, noting the following assumptions as major components of the humanistic organization:

...organizations exist to serve human needs rather than the reverse; people and organizations need each other ... organizations need ideas, energy, and talent ... people need careers, salaries, and opportunities; when the fit between individual and system is poor, one or both suffer ... individuals are exploited or exploit the organizations; a good fit benefits both ... individuals find meaningful and satisfying work, and organizations get the talent and energy they need to succeed. (p.115) 
From the humanistic standpoint, examining the organizational structure of developmental courses is viewed to be more about the individuals working within these departments than the placement of courses. From this viewpoint, regardless of whether or not developmental courses are centralized or decentralized, the most important factor when examining teaching practices is determined by the instructor's own self-efficacy in regard to teaching underprepared students. Various developmental education scholars note that the essential component of teaching underprepared students is the utilization of instructors who are committed to doing so (Perin, 2002). From a human resource standpoint, it is assumed that a 'best fit' between the organizational model and the individuals working within that model offer the best opportunities to improve outcomes.

\section{Organized Anarchy}

As the study of organizations and organizational theory has progressed, scholars have adapted additional organizational theories to help them describe and understand institutions of higher education. Although theoretical models founded in the principles of rationality are commonplace, it is important to address alternative theories of organization as well. For instance, Bryman (1984) noted that “...garbage can, institutional, political, and Marxist...” models provide additional views about the structure of organizations in general. As noted by Baldridge, Curtis, Eker, and Riley (1977), the garbage can model as developed by Cohen, March, and Olsen (1972) distinguishes institutions of higher education as "organized anarchies" convoluted by several ambiguities (p. 131). Cohen and March (1986) argued that leaders within institutions of higher education face “...four fundamental ambiguities” (p. 16). These points include the ambiguity of purpose, the ambiguity of power, the ambiguity of experience, and the ambiguity of success (Cohen et al., 1986). In essence, throughout their work Cohen et al. (1972, 1977, 1979, 
1986) posited that most organizations operate with the presumption that organizational structure will dictate outcomes, that goals are clearly stated, that power is well-defined, that decision making processes are rational, and that success is easily recognizable. Cohen, March, and Olsen (1979), through their examination of decision making within organizations, surmised that the connection between organizational structure and organizational outcomes is loosely-coupled at best. The authors argue that decision making is best described as a garbage can process whereby "[p]references are discovered through action as much as being the basis for action" (Cohen et al., 1979, p. 25). The garbage can theory builds on the open system models of organization, demonstrating that environmental factors and the individuals working within organizations bring with them many variables to influence organizational actions. Cohen et al.'s (1972) organizational model is a direct rejection of rational conceptualizations.

Ultimately, Cohen and March's (1979) work calls for new ways of thinking about organizational theory away from traditional perceptions grounded in rational systems. For instance, Cohen et al. (1986) argued that although leaders utilize rational methods for determining institutional objectives, there is little or no evidence that any stable connection exists between rationally devised objectives and organizational outcomes. March and Olsen (1979) demonstrated the loose connection between objectives and outcomes through the following analysis of individual beliefs and actions:

Most organization theory is purposive. It assumes that behavior and attention follow belief and attitude. Belief and attitudes, in turn, are stable enough so that attention is stable over the course of a choice; and differential levels of attention are predictable from the content of the decision. Decision making activity thus stems from self-interest and is generally attractive so long as the resources being 
allocated are significant ... Our observations suggest a modification of this view. Instead of stable activity levels we find that people move in and out of choice situations. There is considerable variation among individuals, and over time for the same individual, in terms of the degree and form of attention to decision problems. (p. 14)

Baldridge et al. (1977) argued that institutions of higher education suffer from "goal ambiguity," whereby unclear organizational goals impede the process of developing long term strategies and goal attainment (p. 128). The garbage can model would seem to suggest that the differences in outcomes based on a centralized or decentralized placement of developmental education courses would be minimal at best. In part, by adopting the tenets of the garbage can model, it would be presumably difficult to see any statistically significant differences between the two structures based on the assumption that one structure might offer greater outcomes over the other.

\section{Conceptual Framework: Overview}

Although the organizational sciences offer a variety of theoretical positions with which to view, describe, and understand the processes and functions of organizations, this research is framed by the conceptualizations and assumptions associated with rational theories of organization. This study provides a basic examination of two distinct organizational structures generally adopted by community colleges to administer developmental education coursework, centralized or decentralized models, and attempts to determine if the location of these courses within the organization has any affect on students' perceptions of the principles for good practice as prescribed by Chickering and Gamson (1987). To gain greater insight into the placement of developmental education programs and/or courses, this study will examine these programs as 
rational subunits. Moreover, due to the decentralized nature of colleges and universities in general, this research views institutions of higher education as professional bureaucracies. Furthermore, because this study views institutions of higher education as professional bureaucracies, it is important to distinguish the differences between the definitions of centralization or decentralization at the macro level and what is meant by centralized or decentralized developmental education. The following sections will provide details about centralization and decentralization at the department level in regard to developmental education and will provide an outline of the rational bureaucratic and professional bureaucratic conceptualizations used to frame this research.

\section{Centralized and Decentralized Developmental Education}

In general, when researchers discuss the centralization or decentralization of developmental education they are essentially pointing to the departmentalization or coordination schema utilized by one school or another to offer developmental education coursework. This study looks at the coordination of developmental education courses on the department level. In this sense, it is assumed that power for coordination and direction of various college programs like developmental education departments or other academic departments is decentralized away from the top levels of the organization; that is, the coordination and decision making processes for day-to-day operations within these programs is made from within the respective program and not at the top levels. Although the decision to organize developmental education courses one way or another generally evolves from the top levels of the organization, this study is not concerned about power or coordination at the top levels of the organization, it is only concerned about coordination at the subunit level and the effect that course placement might have on students' perceptions; so, when describing developmental education programs, this research is 
essentially describing the placement of developmental education courses and their particular location within the college. If developmental courses are decentralized, then these courses will be found in their respective departments (i.e., developmental math is in the regular math department). In the decentralized model, developmental courses are coordinated by the department head of the regular course department. If developmental courses are centralized, then all of the developmental math and English courses are found in a single department, or a department of developmental education. Within the developmental education department, the department is coordinated by its own department head. This research accepts that there is an overall decentralization of power throughout institutions of higher education and assumes that institutions of higher education can be described as professional bureaucracies. In a traditional sense of the organizational sciences all developmental education courses, whether organized in their own departments or organized in traditional academic departments, would be considered decentralized. The primary questions to consider are where developmental education courses are located and coordinated within the college structure and whether there is a significant difference between students' perceptions regarding their instructors' practices.

\section{Assumptions of Rational Organizations}

There are several assumptions that must be addressed when organizing this study around a rational framework of organization. For example, in regard to their structural view of organization, Bolman and Deal (2003) posited the following assumptions:

- Organizations exist to achieve established goals and objectives

- Organizations increase efficiency and enhance performance through specialization and a clear division of labor 
- Appropriate forms of coordination and control ensure that diverse efforts of individuals and units mesh

- Organizations work best when rationality prevails over personal preferences and extraneous pressures

- Structures must be designed to fit an organization's circumstances (including its goals, technology, workforce, and environment)

- Problems and performance gaps arise from structural deficiencies and can be remedied through analysis and restructuring (p. 45)

These assumptions, and Bolman's and Deal's (2003) descriptions of the structural view of organizations, are directly informed by the rational conceptualizations of organizations as developed through the work of scholars like Weber (1947). As noted by Kuh (2003), Weber (1947) described rational bureaucracies as having the following characteristics: division of labor and specialization, impersonal orientation, hierarchy of authority, rules and regulations, career orientation, efficiency, and ideal type. It is posited that the rational-bureaucratic organization provides a definitive structure capable of helping to stabilize and guide institutions in order to achieve a specific mission or set of goals. Bolman and Deal (2003) argued that “... an organization's structure represents its efforts to align internal processes with the external environment, while simultaneously resolving an enduring set of organizational dilemmas... " (p. 92). These rules, inherent to the bureaucratic structure, allow it to standardize its “...tasks, functions, and processes..." in the hopes that the effectiveness and/or productivity of the organization are improved (Kuh, 2003, p.272). Bolman and Deal (2003) in their analysis of the structural view of organizations noted that the assumptions of the structural view "...reflect a belief in rationality and a faith that the right formal arrangements minimize problems and 
maximize performance" (pp. 44-45). The rational-bureaucracy assumes a logical organization of tasks as a means for controlling the methods of production, which can be seen in institutions of higher education (Kuh, 2003). Examining the concept of rationality in organizational sciences, Bryman (1984) noted that "[o]rganizational arrangements are viewed as the outcomes of meansend decisions to bring situational circumstances and structures into alignment in order to enhance efficiency" (p. 392).

The aforementioned statement by Bryman (1984) highlights partial impetus for rational organization within institutions. Many researchers note that the rational-bureaucracy is devised to achieve specific goals. From this particular view, organizational structure becomes an independent variable formulated to influence specific outcomes. In essence, the division of labor and specialization often departmentalized within the university or community college is done so through a specific attempt to influence some particular outcome: learning assistance centers in the community college, for example, are devised to achieve the goals specific to their primary missions - to help augment student learning and academic success within various courses; the budget office within the college works to develop and monitor budgetary actions in order to achieve the most effective uses of institutional resources; the technology office works to provide the institution with the most effective tools to gather, analyze, and disseminate information; and student services departments plan, organize, and initiate activities to improve the recruitment, retention, and successful transition of students. The primary assumption with each of these departments is that individuals are employed as professional specialists who are trained to perform the routine tasks inherent to the department. Just as academic departments employ specialists in regard to their respective disciplines, other departments within the college or 
university employ specialists who are able to perform the specialized duties associated with their departments or subunits (Kuh, 2003).

The rational model assumes that the structural formats utilized to administer developmental education courses are done so in order to achieve specific goals as well. In most events, developmental education courses are prescribed to students who demonstrate deficiencies within particular content areas with the sole intention of helping them to develop or redevelop the skills necessary to be successful in regular college courses (Boylan, Bliss, \& Bonham, 1997; Breneman \& Haarlow, 1998; Hoyt \& Sorenson 2001; Ignash 1997; Jehangir, 2002; Kolajo, 2004; Kozeracki 2002; McCabe, 2000; NCES,2008; NCES, 2003; Perin, 2002; Phelan, 2000; Phipps, 1998; Roueche \& Roueche, 1999; Roueche, Roueche \& Ely, 2001; Spann, 2000). Most institutions utilize empirical data to determine how well they are meeting these goals. Success rates are often quantified by the pass rates of developmental students and the numbers of those students who enter and are retained in regular coursework, student grade point averages, and the percentages of developmental education students who graduate or transfer to four-year colleges. To achieve these goals, most community colleges organize tasks into functional departments; the work of preparing underprepared college students in a specific subject area is delegated either to a regular academic department or a developmental education department.

Departmentalization itself is a distinguishing component of the rational-bureaucratic organization and provides some additional insight into the central examination of this study. The next section examines the historical growth of departmentalization in higher education and provides an introduction to the conceptual underpinnings that may influence why organizations organize developmental courses the way they do. 


\section{Departmentalization}

Several scholars point out that departmentalization within universities and colleges is the product of the overall growth of these organizations over the last two hundred years (Cohen, 1998; Duryea, 1973; Goldin \& Katz, 1999; Havranek \& Brodwin, 1998; Lucas, 1994; Thelin, 2004). Duryea (1973) described the expansion of departments within universities and colleges as a part of the philosophical and cultural changes that occurred in higher education throughout the $19^{\text {th }}$ century. As the mission of institutions of higher education in the $19^{\text {th }}$ century became more secularized, and a more utilitarian vision for the training of students prevailed, the university and college curriculum grew to see division based on specialization (Cohen, 1998; Duryea, 1973; Goldin \& Katz, 1999; Havranek \& Brodwin, 1998; Lucas, 1994; Thelin, 2004;). Spurred by the industrial growth, economic growth, and land expansion occurring throughout the nation, colleges and universities in the $19^{\text {th }}$ century went from being bastions of the liberal arts curriculum to institutions focused on training students in professional fields (Cohen, 1998; Duryea, 1973; Goldin \& Katz, 1999; Havranek \& Brodwin, 1998; Lucas, 1994; Thelin, 2004). Havranek and Brodwin (1998) noted that "[a]s a consequence of the industrial revolution and its emphasis on specialization, many organizations, including higher education, developed strict departments that contained specialized functions" (p. 116). Havranek et al. (1998) characterized departmentalization as a philosophy of organization "...perceived as a way to enhance the accumulation and dissemination of knowledge" (p. 116). Goldin and Katz (1999) pointed to the formulation of learned societies as a significant point in the separation of specialized fields of study and influence to the creation of departments dedicated to these fields within institutions of higher education. Demonstrating examples in the social sciences, Goldin et al. (1999) highlighted the organization of disciplines based on specialization taking shape at the turn of the $20^{\text {th }}$ century with the formation of societies in economics, psychology, anthropology, and 
political science. As further example, colleges dedicated specifically to agriculture and mechanics were organized in the $19^{\text {th }}$ century to help meet the demand to develop a populace educated and trained in the skills needed as technology was changing; college course offerings became diversified to help train students to participate in the expanding economy of a growing country (Duryea, 1973). Furthermore, driven by increased accessibility and higher enrollments, departmentalization increased greatly with the expansion of the administrative functions needed to manage the day-to-day operations of the organization (Duryea, 1973). With the tremendous growth of colleges in the early $20^{\text {th }}$ century, the college president quickly became the executive administrator overseeing a variety of departments dedicated to managing academic, financial, and student services. Along with the increased accessibility to colleges and universities over the last two centuries has come tremendous growth in the number of these institutions and an increased complexity of their organizational structures.

Departmentalization signifies a rational division of operational tasks. Scholars generally categorize departmentalization into four areas: functional departmentalization, process departmentalization, product departmentalization, and customer departmentalization (Lussier, 2009). Most institutions of higher education can be described as utilizing the functional department model. For the most part, functional departmentalization is based on specialization: job functions are concentrated into rational divisions based on the work that needs to be done. As colleges and universities grew throughout the $20^{\text {th }}$ century, departmentalization became a product of the need to rationally organize tasks into subunits based on the presupposition that by doing so these institutions would increase productivity and ensure specific outcomes based on function. From the rational perspective, by achieving individualized departmental goals, each department helps to fulfill the general strategic goals of the organization. 
The modern community college is as easily distinguishable by its departments as is the large research university. Community colleges are comprised of a variety of departments that often include those organized under a categorization of academic affairs, student services, business processes, facilities management, etc. One question faced by administrators organizing developmental courses within these institutions, however, centers round the idea of how to best categorize these particular types of courses. Because the rational nature of institutions of higher education points to the notion of functional departmentalization as the means by which to determine course placement, developmental courses are organized either by their categorization of academic discipline and placed into preexisting academic departments or placed into a department organized around a holistic philosophy of student development.

Some scholars suggest that the problem of determining developmental education course placement stems from how institutions define developmental education and whether or not they adopt the specific tenets inherent in a developmental philosophy (Arendale, 2005). Arendale (2005) pointed out distinctions between developmental education and remedial education and suggested that these philosophical differences may help to shape how administrators and institutions perceive the task of providing student support in pre-college courses. Arendale (2005) noted that developmental education focuses on the cognitive and affective attributes of students while the traditional focus of remedial education "...was primarily on cognitive deficits and not improvements in the affective domain" (p. 69). The issue of where to locate developmental education courses may then be viewed as a dilemma of functional departmentalization (i.e., should these courses be organized within an area that functions solely to help prepare underprepared students, or should these courses be located in an area that functions primarily as academic field experts). Regardless, departmentalization is a significant 
component of the rational structure of institutions of higher education and provides additional insight into the conceptualizations used to guide this study.

\section{Section Summary}

Many institutions of higher education utilize a definitive organizational structure to achieve the goals of the agency. Although emergent theories on organization look past the rational/structural conceptualizations rooted in bureaucratic-type institutions, a glimpse at the organizational outline of any community or four-year college provides stakeholders with a general understanding about the functional/structural apparatuses used by these institutions. For the most part, modern colleges are devised of a number of departments and subunits utilized to perform certain functions; professionals are hired to perform specialized duties; rules and procedures dictate the official interactions of employees; a clear chain of command guides the lines of power and authority; the general organization, subunits, and departments pursue defined goals and objectives; standardization guides tasks; and a high level of specialization and professionalization allow for the decentralization of decision making power from the top levels to departmental levels.

The rational/structural model provides just one way of describing modern colleges. As noted in previous sections, new organizational theories continue to help evolve the way scholars think in regard to organizational behaviors, how institutions organize, why they organize in a particular manner, how they change, and what affect, if any, organizations have on individuals and other dependent variables. The rational/structural framework used in this study functions here as a way to describe a very general level of institutions of higher education. As previous authors have noted, educational organizations may be better understood as "...multi-faceted social phenomena rather than being viewed from a singular [theoretical] perspective that 
competes with alternative perspectives" (Berger, 2000, p. 179). The rational/structural framework offers a simple form to describe institutions in general and to specifically provide an understanding of the development of functional departments within these organizations. For the most part, the placement of developmental coursework is a matter of how it is departmentalized. The purpose of this research is to examine these two specific developmental education department-types to determine if they produce different perceptions from their students in regard to the learner-centered practices posited by Chickering and Gamson (1987); therefore, it is assumed that these organizational structures act as functional departments designed to meet these specific objectives.

\section{Developmental Education}

Several scholars view developmental education as a product of the Student Personnel Point of View (1949) movement (Arendale, 2005; Higbee, Arendale, \& Lundell, 2005). These authors argue that developmental education differs from remedial education largely in part because of its concentrated focus on student development and the premise that the goal of higher education should be to focus on the development of the whole student rather than "...merely on students' intellectual development" (Higbee, Arendale, \& Lundell, 2005, p. 6). Drawn from this statement released by the American Council on Education (1949), Higbee et al. (2005) pointed out that the Student Personnel Point of View (1949) led the way for changes in the way colleges and universities viewed their goals for students. The mission of the Student Personnel Point of View (1949) is clearly represented in the following excerpt:

The student personnel point of view encompasses the student as a whole. The concept of education is broadened to include attention to the student's wellrounded development--physically, socially, emotionally, and spiritually--as well 
as intellectually. The student is thought of as a responsible participant in his [sic] own development and not as a passive recipient of an imprinted economic, political, or religious doctrine, or vocation skill. As a responsible participant in the societal processes of our American democracy, his [sic] full and balanced maturity is viewed as a major end-goal of education and, as well, a necessary means to the fullest development of his [sic] fellow citizens. From the personnel point of view any lesser goals fall short of the desired objectives of democratic educational processes and is a real drain and strain upon the self-realization of other developing individuals in our society. (p. 17)

Evans, Forney, and Guido-DiBrito (1998) emphasized that the Student Personnel Point of View "...was a reminder to the higher education community that in addition to the contributions of research and scholarship, the personal and professional development of students was (and remains) a worthy and noble goal" (p. 6). This statement by Evans et al. (1998) demonstrates that the Student Personnel Point of View (1949) was also a direct reaction to the changes that had occurred in the focus of higher education throughout the mid $19^{\text {th }}$ century and early parts of the $20^{\text {th }}$ century. The Student Personnel Point of View (1949) argued that although earlier models of higher education were more focused on the complete development of the college student, the formation of the " ...modern research-centered German university early in the $19^{\text {th }}$ century led to the abandonment of this personal concern for students and centered on an intellectualistic concern" (p.18). The Student Personnel Point of View (1949) signifies a renewed focus on college students as unique individuals who bring with them an array of beliefs and experiences that ultimately affect their learning experiences within the college or university environment. The Student Personnel Point of View (1949) argued that in order to ensure 'democratic 
educational processes' institutions of higher education have to assume the responsibilities necessary to help perpetuate the full human development of each individual.

\section{Historical Background}

The focus on 'democratic educational processes' in institutions of higher education was perhaps initially spurred by the federal government's enactment of the Morrill Acts of 1862 and 1890 (Casazza, 1999; Casazza \& Silverman, 1996; Stephens, 2003). With the passage of these federal laws, colleges and universities in the United States became more accessible to the general public, thus perpetuating the democratic mission to provide all citizens with the opportunity for higher learning (Casazza, 1999; Casazza \& Silverman, 1996; Stephens, 2005). Scholars point out that remedial education programs have a long history within higher education in the United States because of the increases in enrollments brought on by improved accessibility (Arendale, 2005; Casazza, 1999; Casazza \& Silverman, 1996; Stephens, 2003). With the expansion of the college curriculum, increases in student enrollments, and limited opportunities for secondary education throughout the $19^{\text {th }}$ century, colleges and universities began to realize the necessity for programs to help prepare new students to undertake a challenging college curriculum (Arendale, 2005; Casazza, 1999; Casazza \& Silverman, 1996; Stephens, 2003). As secondary education programs began to take shape throughout the $19^{\text {th }}$ century, institutions like the University of Wisconsin developed preparatory programs as early as 1849 to provide students with conditional admission into the university and to help them prepare for the demands of the college curriculum (Arendale, 2005; Casazza \& Silverman, 1996; Stephens, 2003;). Stephens (2003) noted that even after the development of college entrance standards devised in the 1890s by the College Entrance Examination Board (CEEB), colleges and universities at the turn of the $20^{\text {th }}$ century still experienced an overwhelming number of students who were unprepared for college. While 
institutions like Harvard provided remedial courses to improve the reading skills of its students, institutions like the University of Minnesota developed preparatory programs to improve retention of its undergraduates (Casazza, 1999; Stephens, 2003). Arendale (2005) pointed out that remedial education was utilized by colleges and universities from the 1860 s through the 1960s to help students develop the skills they needed to engage in the regular college curriculum.

Around the same time that the Student Personnel Point of View and student development movement began to take shape throughout the 1940s, colleges in the United States began to see even greater increases in their enrollments. Stephens (2003) pointed out that the influx of college enrollments after World War II came in part because of the GI Bill of Rights and the Civil Rights movement of the 1950s and 1960s. Stephens (2003) demonstrated that "[b]y the fall of 1946, over 1 million veterans had taken advantage of [the GI Bill]" (p. 22). Both the GI Bill and the Civil Rights movement prompted an increase in college enrollments and brought forth more students who were traditionally unprepared to attend college. Stephens (2003) noted that this influx in students seeking higher education allowed four-year colleges to become more selective, thereby motivating a rise in community and junior colleges to facilitate students who were underprepared academically. With increased access to institutions of higher learning, more and more first-generation students began to seek out a college education as well. The 1970s saw an influx of students who were eager to attend college as the first members of their families to do so (Casazza, 1999; Casazza \& Silverman, 1996; Stephens, 2003). Stephens (2003) pointed out that these first-generation students traditionally scored in the lower third on academic examinations (Stephens, 2003).

Most scholars note that the moniker 'developmental education' first appeared in higher education in the 1970s (Arendale, 2005; Casazza, 1999; Casazza \& Silverman, 1996; Higbee, 
Arendale, \& Lundell, 2005). Arendale (2005) pointed out the differences between developmental education and several other programs of the 1960s and 1970s, noting the tendency for many administrators and scholars to mistakenly interchange the title of developmental education with those of remedial education, compensatory education, and learning assistance programs. Where remedial education historically focused on the "...skill deficits of students and educational approaches that addressed these identified needs", developmental education became a program organized to focus on all aspects of students' development in order to help them achieve success in basic courses and beyond (Arendale, 2005, p. 68). Boylan et al. (2007) defined developmental education with the following:

Developmental education refers to $\mathrm{a} b$ road range of courses and services organized and delivered in an effort to help retain students and ensure the successful completion of their post-secondary education goals. Furthermore, these courses and services are generally delivered according to the principles and theories of adult development and learning, hence the term 'developmental' education. (p. 2)

Although a variety of researchers point out that remedial education has been a part of higher education in the United States since the influx of college enrollments throughout the industrial revolution and beyond, developmental education programs arose in the late 1960s and early 1970s as a response to increased enrollments and the movement to focus more on the development of the whole student (Casazza, 1999; Casazza \& Silverman, 1996).

Scholars often argue that remedial education may be considered a definitive component of developmental education, but remediation does not necessarily define developmental education (Arendale, 2005; Casazza, 1999; Casazza \& Silverman, 1996). For most 
developmental education scholars, developmental education is grounded in the concepts associated with student development. Higbee et al. (2005) pointed out that the conceptual roots of developmental education span from both student development theory and transformative theory. Higbee et al. (2005) mark the work of prominent student development scholars Arthur Chickering (1969), Alexander Astin (1984, 1985), and William Perry (1970) as the most influential in the progression of developmental education programs over the last 40 years.

\section{Chickering's Theory of Identity Development}

Higbee et al. (2005) highlighted Chickering's work on identity formation as an important contribution to the advancement of developmental education. Based on direct research with students and colleges from 1965 to 1993 , Chickering developed a theory of identity formation framed within seven vectors (Evans, Forney, and Guido-DiBrito, 1998; Higbee, Arendale, \& Lundell, 2005). These vectors include developing competence; managing emotions; moving through autonomy toward interdependence; developing mature interpersonal relationships; establishing identity; developing purpose; and developing integrity (Evans, Forney, and GuidoDiBrito, 1998; Higbee, Arendale, \& Lundell, 2005). As noted by Evans et al. (1998), Chickering expressed these levels of development as vectors in order to highlight the dynamicity associated with individual development through identity formation. Evans et al. (1998) pointed out the differentiation in progression for individuals, noting that "[a]lthough not rigidly sequential, vectors do build on each other, leading to greater complexity, stability, and integration as the issues related to each vector are addressed" (p. 38). Several scholars offer that Chickering's ideas on identity development are important for all demographics of developmental students, including nontraditional students (Higbee, Arendale, \& Lundell, 2005). 


\section{Perry's Theory of Intellectual and Ethical Development}

Higbee et al. (2005) argue that Perry's theory of intellectual and ethical development has historically helped guide developmental education instructors as they have worked with underprepared students. Higbee et al. (2005) noted that Perry's theory helps instructors better understand student behavior by pointing out that students often enter college viewing the world from a “dualistic perspective” (p. 6.). Citing Perry’s work (1968), Evans et al. (1998) outlined the following positions of Perry's theory:

- Basic Duality

- Multiplicity Prelegitimate

- Multiplicity Legitimate but Subordinate

- Multiplicity Coordinate

- Relativism Subordinate

- Relativism

- Commitment Foreseen

- Evolving Commitments (p. 130)

Basic Duality suggests that students make meaning through a dichotomous worldview (Evans et al., 1998). From this perspective, students entering college wrongly assume that “...the right answers exist for everything" (Evans et al., 1998, p. 131). Each of these positions provides a differing level of development in regard to how students view their experiences.

Perry's theory falls in with the cognitive-structural line of student development theories. As suggested by Evans et al. (1998), Perry's theory is viewed as a continuum of development with no predetermined duration in which individuals might remain regarding the aforementioned 
nine positions. Each position describes how students perceive the world in regard to knowledge formation and ethical development.

\section{Astin's Theory of Student Involvement}

In his theory of student involvement, Astin (1984) posited that the more time and energy students expend in educationally purposeful activities, the more they will benefit. Astin (1997) argued that “...student involvement has generally beneficial effects on a wide range of developmental outcomes." Astin's theory is outlined by the following features:

1. Involvement is the investment of physical and psychological energy in various objects. The objects may be quite general (e.g., the student experience) or specific (e.g., preparing for a chemistry examination);

2. Regardless of its object, involvement occurs along a continuum; that is different students exhibit different degrees of involvement in a given object or task with the same student manifesting different degrees of involvement in different objects at different times;

3. Involvement has both quantitative and qualitative features. The extent of a student's involvement in academic work, for instance, can be measured quantitatively (e.g., hours devoted to studying) and qualitatively (e.g., whether the student reviews and comprehends reading assignments or simply stares at the textbook and daydreams);

4. The amount of student learning and personal development associated with any educational program is directly proportional to the quality and quantity of a student's investment of time and energy;

5. The effectiveness of any educational policy or practice is directly related to the capacity of that policy or practice to increase student involvement. (Astin, 1984, p. 298) 
Upon close examination, Astin's (1984) theory of student involvement forwards a studentcentered model of thinking about pedagogical function. Astin (1984) looks at the theory of student involvement as a way to amalgamate the primary theoretical tenets found within three pedagogical theories noted as subject-matter theory, resource theory, and individualized theories. Astin (1984) posited that student involvement theory provides a new way for academicians to think about and develop new policies, procedures, and activities that will improve student learning. Instead of focusing on teacher-centered practices (i.e., exposing students to the right subject matter), student involvement theory provides instructors with a framework that helps them to develop processes that will engage students in the subject matter. Astin argues that the student involvement theory " ...encourages the instructor to focus less on content and teaching techniques and more on what students are actually doing-how motivated they are and how much time and energy they are devoting to the learning process" (p. 305).

\section{Professional Organizations and Best Practices in Developmental Education}

Developmental education programs are prevalent throughout the United States, with over $98 \%$ of community colleges offering developmental education courses in the year 2000 (NCES, 2003). For the last 30 years there has been an extensive effort on the part of researchers and professional organizations to track the growth of these programs and to establish best practices to help guide and improve teaching and learning for students entering college underprepared. Professional organizations, like the National Center for Developmental Education (NCDE) established in 1977 and the National Association of Developmental Education (NADE), have led the way in promoting a continued professional effort to find solutions for improving the educational experiences of developmental education students. Boylan et al. (2007) argued that with the continued professionalization of developmental education through the establishment of 
organizations like the NCDE “...states are taking [developmental education] very seriously and encouraging their colleges and universities not only to provide developmental education but to provide it using the best available research and practice" (p. 4). NADE has been active in research and scholarship involving developmental and remedial education over the last 30 years as well, and currently publishes the Journal of Developmental Education in which it helps to promote its mission "...to improve the theory and practice of developmental education at all levels of the educational spectrum, the professional capabilities of developmental educators, and the design of programs to prepare developmental educators" (NADE Fact Sheet, 2009, side 1). NADE has over 3000 members with 30 chapters representing all 50 states (NADE Fact Sheet, 2009).

One goal for professional organizations like NADE and NCDE has been to promote scholarship and research to improve practices in developmental education. Over the last few years a variety of scholars have worked to pinpoint concepts that appear promising for the improvement of best practices for developmental education programs and instructors. For instance, Boylan et al. (1997) outlined the following:

- presence of centralized program organizational structure

- $\quad$ presence of mandatory assessment of students

- $\quad$ presence of mandatory placement of students

- availability of tutor training

- availability of advising/counseling services

- presence of program evaluation (p.1)

Smittle (2003) outlined six principles of practice for developmental education instructors:

- commit to teaching underprepared students 
- demonstrate good command of the subject matter and the ability to teach a diverse student population

- address noncognitive issues that affect learning

- provide open and responsive learning environments

- communicate high standards

- engage in ongoing evaluation and professional development (pp. 11-14)

Sheldon (2002) promoted the following best practices for framing developmental education programs:

- program leadership that includes regular meetings of all those involved in the delivery of developmental courses and services, articulation of common goals and objectives for all developmental courses and services, and integration of developmental courses and academic support services

- building a committed faculty through continued opportunities for professional development

- program Improvement through Systematic Evaluation

In their address, titled "Refocusing Developmental Education," Brothen and Wambach (2004) listed the following as “...key concepts for highly effective educators":

- continue and refine literary skill development courses

- $\quad$ vary course placement requirements based on student goals and program of study

- develop a range of placement testing procedures

- integrate alternative teaching/learning approaches

- use theory to inform practice

- integrate underprepared students into mainstream curriculum 
- adjust program delivery according to institutional type (pp. 18-22)

Shwartz and Jenkins (2007) provided an exhaustive list of good practices for developmental education programs that center round the following points:

- program management and organization

- assessment instruction and curriculum

- $\quad$ student supports

- faculty

- $\quad$ roles for public policy (p. 3)

Other concepts of good practice include Chickering and Gamson's (1987) principles for good practice in undergraduate education. These principles act as general guides for helping colleges to develop processes that encourage learner-centered approaches to instruction. Chickering's and Gamson's (1987) principles have been used by scholars to develop curricula and instructional practices throughout institutions of higher education and are considered by many postsecondary educators as essential standards for improving student learning. The following section outlines the historical development of the seven principles for good practice, provides insight into the research supporting the validity of the principles, and demonstrates how scholars have used these principles to drive curricula and program development.

\section{Seven Principles for Good Practice in Undergraduate Education}

Chickering's and Gamson's (1987) principles for good practice in undergraduate education are widely lauded among scholars as the premier guides for helping teachers improve the postsecondary learning experiences of undergraduate students. These seven principles, developed from a wide body of research and the collaboration of a host of scholars, were first published in 1987 and posit that good practice includes the following principles: encouraging 
student/faculty contact; encouraging cooperation among students; encouraging active learning; providing prompt feedback; emphasizing time on task; communicating high expectations; and respecting diverse talents and ways of learning (Gamson, 1991). Gamson (1991) argued that these principles “...distill findings from decades of research on the undergraduate experience..." (p. 5). Gamson, Chickering, and Barsi's inventories were first published for college faculty and for institutions and have subsequently been transformed into an inventory for use by students (Gamson, 1991). Between 1987 and 1991 colleges and universities ordered over 500,000 copies of these inventories; there have since been hundreds of thousands distributed within the United States and around the world (Gamson, 1991; Kuh \& Vesper, 1997b). Citing a variety of scholars, Pascarella et al. (2006) noted that "[e]xtensive evidence exists to support the predictive validity of Chickering and Gamson's (1987) principles for good practice in undergraduate education" (p. 58).

The 7 Principles for Good Practice in Undergraduate Education: Faculty Inventory (1989) came about as an outgrowth of the publication of the principles in 1987. Initially the seven principles were released within an article published in the American Association of Higher Education Bulletin (1987), primarily as an educative statement about good practices in undergraduate education (Gamson, 1991). The initial principles were devised through a collaborative effort led by Gamson and Chickering who, at the time, were both members of the American Association of Higher Education (AAHE) (Gamson, 1991). Chickering and Gamson assembled a taskforce of researchers and scholars with expertise in higher education and student development and charged them with the task of developing "... a statement of principles, to be widely disseminated among the academic community..." (Gamson, 1991, p.6). After developing and then publishing the principles in 1987, Gamson and Chickering embarked on the task of 
distilling the principles into an inventory that would act as " ... a self-assessment instrument for faculty" (Gamson, 1991, p. 9). The faculty and institutional inventories were published in 1989 (Gamson, 1991).

A variety of researchers have employed Gamson's and Chickering's (1987) principles to explore processes for improving student engagement and learning in the field of postsecondary education (Bangert, 2004; Batts, 2008; Chizmar \& Walbert, 1999; Cruce, Wolniak, Seifert, \& Pascarella, 2006; Graham, Cagiltay, Lim, Craner, Duffy, \& Braxton, 2001; Hu \& Kuh, 2001; Koeckeritz, Malkiewicz, \& Henderson, 2002; Koljatic \& Kuh, 2001; Kuh, Pace, \& Vesper, 1997a; Kuh et al., 1997b; Olsen \& Simmons, 1998; Pascarella, Wolniack, Cruce, \& Blaich, 2004; Pascarella, Cruce, Umbach, Wolniak, Kuh, Carini, Hayek, Gonyea, \& Zhao, 2006; Pontius \& Harper, 2006; Ritter \& Lemke, 2000; Smittle, 2003; Sorcinelli, 1991). For example, some researchers argue that the principles of good practice may provide a better focus for accountability efforts in higher education than merely assessing learning outcomes (Kuh et al., 1997a). Kuh et al. (1997a) argued that Gamson's and Chickering's (1987) principles for good practice function as process indicators that better allow institutions to assess “...whether activities and opportunities for learning are in ample supply and whether students are taking advantage of the institution's learning resources" (p. 436). Kuh et al. (1997a) argued that while outcomes data provide information about what students have attained, assessing process indicators can provide institutions with a clearer picture about the institutional behaviors and processes being utilized to ensure better learning outcomes for students.

The literature demonstrates that more and more programs are utilizing the principles of good practice to develop processes for course and program development. With the integration of web-based courses over the last several years, a variety of publications have explored how these 
principles can bring quality to student experiences. For example, Chizmar et al. (1999) utilized the principles for good practice to guide their development of a web-based statistics course for undergraduates. Graham et al. (2001) utilized the principles for good practice to evaluate online courses in a professional school. Koeckeritz et al. (2002) utilized Chickering's and Gamson's (1987) principles to analyze online nursing courses. Pontius et al. (2006) examined the principles for good practice in the context of graduate schools. Pascarella et al. (2006) utilized the principles for good practice to determine if correlations existed between institutional practices and selectivity ratings. Batts (2008) explored the differences between instructor and student perceptions regarding the seven principles in online technology courses.

Ultimately the significance of process indicators like Chickering's and Gamson's (1987) is determined by their ability to improve specific outcomes. The predictive validity of the principles for good practice have been studied extensively by a variety of scholars (Kuh et al., 1997a; Kuh et al., 1997b; Pascarella et al., 2006; Pascarella et al., 2004; Sorcinelli, 1991). Kuh et al. (1997a) found that "...active learning and cooperation among students...were the best predictors of [academic] gains for men and women [undergraduates]..." (p. 446). Citing a variety of authors, Pascarella et al. (2004) argued that "[e]ven in the presence of controls for important confounding influences, various measures of the good practice dimensions are significantly and positively linked to desired aspects of cognitive and noncognitive growth during college" (p. 58).

There is, however, little research available evaluating developmental education programs' use of Gamson's and Chickering's (1987) principles for good practice. Although some data exist supporting the centralization over decentralization of developmental education programs based on student outcomes, there has been little or no attempt to determine if 
differences exist between centralized and decentralized developmental programs and student's perceptions regarding the process indicators developed by Chickering and Gamson (1987). As Kuh et al. (1997a) have proposed, by examining process indicators like the principles for good practice, organizations are afforded the opportunity to determine both organizational and student behaviors in the context of the learning environment and, ultimately, are empowered to provide the guidance, training, and support necessary to ensure that programs are developing researchbased practices that have the best chances for facilitating student success.

\section{Centralization versus Decentralization}

Some scholars argue that highly centralized, highly coordinated, or departmentalized organizational structures are the most effective forms for offering developmental courses (Boylan, 2002; Boylan, Bliss, \& Bonham, 1997; Gerlaugh, Thompson, Boylan, \& Davis, 2007; Kozeracki \& Brooks, 2006). Boylan, Bliss, and Bonham (1997) argued that a relationship exists between "... centralized or well coordinated administrative structures..." and academic success in developmental education students (p. 9). In their study, Boylan et al. (1997) found that "[s]tudents participating in centralized developmental programs were more likely to be successful than students participating in decentralized programs" (p. 4). Boylan et al. (1997) found that students attending centralized programs had higher first term grade point averages, cumulative grade point averages, retention rates, and math and English grades when compared with students attending decentralized programs. Carter, Hashway, and Sandeford-Lyons (1999) found that students who had participated in centralized developmental education programs throughout Louisiana had higher grade point averages than those students who had attended decentralized programs. In addition, Carter et al. (1999) found that “...the negative impact of decentralized (departmental) program delivery is slightly greater for males than females" (p. 45). 
Many scholars favor a highly coordinated developmental education structure over a centralized or decentralized structure (Perin, 2002). Researchers posit that an integrated approach to developmental education programs allows students to attend courses in regular departments and gain valuable experiences that will help with transitions into the regular curriculum, while at the same time providing a well-structured mission focused on developing underprepared students (Perin, 2002). Perin (2002) and McCabe (2000) argued that, in order to minimize any negative effects caused by segregating students based on remedial needs, colleges should provide a highly coordinated structure that allows students to integrate into regular college departments.

\section{Soft Paradigmatic versus Hard Paradigmatic Disciplines}

Along with comparing centralized courses to decentralized courses, this study also compares the perceptions of math students to English students and math instructors to English instructors. Braxton, Olsen, and Simmons (1998) demonstrated a difference between the paradigmatic development of disciplines such as those found in the math and sciences when compared to disciplines such as history, psychology, and sociology. Braxton et al. (1998) argued that these disciplines can be categorized as having either hard paradigmatic structures or soft paradigmatic structures, respectively. According to Braxton et al. (1998), paradigmatic development refers to "...the extent to which members of a discipline agree about theory, methods, techniques, and the importance of the problems for the discipline to pursue” (p. 301). Braxton et al. (1998) argued the following:

...low paradigmatic discipline faculty tend to value student character development, emphasize the development of critical thinking skills, use discursive or student-centered teaching practices, and favor the use of program review and 
student assessment to improve teaching and learning more than do their counterparts in disciplines exhibiting high paradigmatic development. (p. 301) In their 1998 study, Braxton et al. investigated instructors' use of the principles for good practice by disciplines categorized as having a hard paradigmatic development or soft paradigmatic development structure. The researchers used the seven principles as the seven dependent variables for the study and surveyed a total of 114 faculty members between the College of Arts and Sciences and the School of Business. Braxton et al. (1998) found that the two groups differed statistically on four of the seven principles with the low paradigmatic group scoring higher averages on the principles where differences were detected. There were no statistically significant differences between groups on three of the principles. The low paradigmatic group scored higher averages on Principle 1 (Good Practice Encourages Student-Faculty Contact), Principle 3 (Good Practice Encourages Active Learning), Principle 6 (Good Practice Communicates High Expectations), and Principle 7 (Good Practice Respects Diverse Talents and Ways of Learning).

The findings published by Braxton et al. (1998) argued that differences exist in the instructional practices between instructors based on the discipline areas in which they practice. These findings suggest that differences detected between developmental math and English students or math and English instructors may be influenced directly by what Braxton et al. (1998) have termed the affinity discipline hypothesis. In part, this study will attempt to determine if there are differences in the perceptions of students attending developmental math courses and developmental English courses in regard to their 
instructors' practices. At the same time, this study will compare developmental math and English instructors' perceptions in regard to their use of the principles for good practice.

\section{Summary}

Chickering and Gamson's (1987) principles for good practice provide a basic set of standards for helping postsecondary teachers improve their classroom practices. Scholars contest that these principles are empirically linked to improvements in a variety of cognitive and noncognitive measures for college students (Astin, 1993; Chickering \& Reisser, 1993; Pascarella et al., 2004; Whitt, \& Associates, 1991). At the same time, many authors suggest that centralization may be superior over decentralization when it comes to organizing developmental education programs (Boylan, Bliss, \& Bonham, 1997; Gerlaugh, Thompson, Boylan, \& Davis, 2007; Kozeracki \& Brooks, 2006). The current study will attempt to determine if differences exist between these organizational structures and students' perceptions of Gamson and Chickering's (1987) principles for good practice. Chapter Two provided an overview of various theories of organization and provided a conceptual basis for this study by examining the background of developmental education in the United States, highlighting the philosophical and historical underpinnings for programs developed to remediate underprepared college students. Chapter Two ended by providing an overview of Chickering and Gamson's (1987) principles for good practice, by demonstrating various authors' perspectives on organizational structure and outcomes in developmental education programs, and by providing research findings associated with hard and soft paradigmatic disciplines. Chapter Three will provide a description of the methodology for this research. Chapter Three will detail the population, the sample, sampling procedures, instruments used to collect data, data analysis techniques, and the limitations of the study. 


\section{Chapter Three: \\ Research Methodology}

\section{Introduction}

This research attempted to determine if statistically significant differences existed between the perceptions of students attending centralized and decentralized developmental education courses situated in four public Appalachian community colleges in regard to their instructors' use of the principles for good practice. In addition, this study also attempted to determine if there were statistically significant differences between students attending developmental education courses and instructors teaching in developmental education courses in regard to their perceptions of the principles for good practice occurring in these courses. This research also attempted to determine if there were significant differences in the perceptions of students attending developmental English/writing courses and students attending developmental mathematics courses in regard to each of the principles for good practice in undergraduate education. Finally, this research attempted to determine if there were significant differences between instructors' perceptions regarding the principles for good practice based on subject taught (i.e. English/writing and mathematics).

Because the independent variables were preexisting and could not be manipulated by the researcher, this research utilized a causal-comparative methodology. A multivariate analysis of variance (MANOVA) was utilized to determine if overall significant differences existed between groups regarding each research question. The following section provides an overview of the research methodology, including a description of the research population, sampling procedures, instrumentation, and data analysis. 


\section{Population}

The populations for this study were students attending on-campus developmental education English/writing and math courses and instructors teaching developmental English/writing and math courses in public community colleges located in the Appalachian region. Six community colleges were used for this research study; however, only four were used to answer research question one. Two of the colleges utilized a centralized model for delivering developmental courses while the other two utilized a decentralized model as determined through a survey developed and administered by the researcher (see Appendix A).

\section{Sample and Sampling Procedure}

The population of institutions for this study was selected from a list of public community colleges located within the Appalachian region of the United States. First, the researcher identified all public community colleges situated and operating within the Appalachian region of the United States. According to the Appalachian Region Commission (ARC), the Appalachian region “...includes all of West Virginia and parts of 12 other states: Alabama, Georgia, Kentucky, Maryland, Mississippi, New York, North Carolina, Ohio, Pennsylvania, South Carolina, Tennessee, and Virginia" (ARC, 2010). The researcher utilized the classification system developed by the Carnegie Foundation for the Advancement of Teaching (2010) to identify all public associate-degree granting community colleges operating within the 13 states of the Appalachian region. Utilizing the listing of counties provided by the ARC, the researcher then identified the community colleges from each state that were operating within a county of the Appalachian region by cross-referencing the physical addresses (i.e., street, city, county) found on each institution's web site with the counties listed by the ARC within each respective state. There are 420 counties in the Appalachian region (ARC, 2010) (see Appendix B). 
After identifying all public associate-degree granting institutions within the Appalachian region, the researcher then sent the Developmental Education Organization-type Survey (DEOS) (see appendix A) to the primary academic officers of each institution. The DEOS allowed the researcher to determine if developmental courses were decentralized and offered in regular academic departments or if these courses were highly coordinated and offered in a centralized department designated to provide students with developmental education courses. Research Question 1 was concerned only with comparing developmental education programs that offer courses through either a centralized or decentralized model. Any colleges offering developmental courses through a mixed model (i.e., some colleges may have a designated coordinator for developmental courses but offer courses within regular course departments) were not considered for Research Question 1. After determining the structure utilized by each community college to offer developmental courses, the researcher selected three community colleges that utilized a centralized model and three that utilized a decentralized model (After further review of the six schools selected, only four of the colleges were utilized to address Research Question 1. These four schools appeared to use more orthodox models of centralization or decentralization to offer developmental coursework).

All of the six community colleges were utilized to address Research Questions 2, 3, and 4. All of the colleges in this study were selected utilizing the following system:

- The schools selected were small two-year institutions as denoted by the Carnegie classification system;

- The schools selected granted no degree higher than an Associates degree; and

- The schools selected were located within counties situated in the Appalachian region. 
After selecting six community colleges operating within the Appalachian region, the researcher requested permission for their participation in this dissertation research. The researcher requested permission from the Academic Provost or Vice President of Academic Affairs for their institution's participation in the research and requested that they allow the researcher to contact the chair, instructors, and students of each academic or developmental education department to request their participation in this study (see Appendix C).

After institutions were selected for this study, the researcher collected descriptive information, including classification information provided by the Carnegie Classification web site, enrollment data, population demographics, and other information relevant to providing a comprehensive description of each institution.

After the selection of locations, the number of students attending developmental courses was determined through each institution's enrollment management system. The researcher determined the numbers of students attending developmental courses in decentralized programs and students attending courses in centralized developmental education courses (see Table 4). This research was concerned only with students attending developmental education courses in math and English/writing on-campus at the selected community colleges. This research did not sample any distance-education or "online only" courses.

The numbers of students attending developmental mathematics and English courses and instructors teaching within developmental mathematics and English courses were identified in each of the community colleges (see Table 4). The researcher requested permission from the academic provost or vice president for academic affairs of each institution to gain access to these data fields. 


\section{Method}

This research used a causal-comparative methodology because it was attempting to determine if there was a causative relationship between the independent and dependent variables. A distinction between causal-comparative from experimental research is that in causalcomparative research the researcher has little control over the independent variable. In the case of this study, the independent variable preexisted as the organizational structure used to offer developmental courses by each community college. After selecting the population sample, students and faculty were administered a survey developed using statements from Chickering, Gamson, and Barsi's (1989) faculty inventory of principles for good practice. A sample of convenience was used for this study. The researcher administered surveys to students while they were attending courses within the final six-weeks of the fall semester (see Appendix D). The researcher requested that each participating institution provide contact information for each instructor. Instructors were contacted and provided with a letter of participation (see Appendix E) from the researcher. Instructors were provided with either an internet link leading to the instructor edition of the survey or provided a paper copy (see Appendix F).

\section{Instrumentation}

The survey tool for this research utilized statements selected from Chickering, Gamson, and Barsi's (1989) 7 Principles for Good Practice in Undergraduate Education: Faculty Inventory. The faculty survey used for this study utilized the statements in their original form as written in the original faculty inventory by Chickering et al. (1989). Although there are ten original items for each of the seven principles for a total of 70 items, the researcher selected and used only five items to represent each of the seven principles (see Table 1). 
Table 1

Point Range for Each Survey Item and Dependent Variable Category

\begin{tabular}{|c|c|c|}
\hline Dependent Variable Category & $\begin{array}{c}\text { Scale for Each } \\
\text { Statement }\end{array}$ & $\begin{array}{c}\text { Scale for Each } \\
\text { Category }\end{array}$ \\
\hline $\begin{array}{l}\text { Principle } 1 \\
\text { Good Practice Encourages Student-Faculty } \\
\text { Contact }\end{array}$ & $1-5$ & $5-25$ \\
\hline $\begin{array}{l}\text { Principle } 2 \\
\text { Good Practice Encourages Cooperation }\end{array}$ & & \\
\hline Among Students & $1-5$ & $7-35$ \\
\hline $\begin{array}{l}\text { Principle } 3 \\
\text { Good Practice Encourages Active Learning }\end{array}$ & $1-5$ & $9-45$ \\
\hline $\begin{array}{l}\text { Principle } 4 \\
\text { Good Practice Gives Prompt Feedback }\end{array}$ & $1-5$ & $6-30$ \\
\hline $\begin{array}{l}\text { Principle } 5 \\
\text { Good Practice Emphasizes Time on Task }\end{array}$ & $1-5$ & $5-25$ \\
\hline $\begin{array}{l}\text { Principle } 6 \\
\text { Good Practice Communicates High } \\
\text { Expectations }\end{array}$ & $1-5$ & $6-30$ \\
\hline $\begin{array}{l}\text { Principle } 7 \\
\text { Good Practice Respects Diverse Talents and } \\
\text { Ways of Learning }\end{array}$ & $1-5$ & $7-35$ \\
\hline
\end{tabular}

Surveys were developed from Chickering, Gamson, and Barsi’s (1989) original work for students attending developmental courses in both English and math (see Appendices G and H). Items from each of the seven principles were selected using an objective reviewer who had experience as a chair of and instructor in a developmental education program. The reviewer was asked to review the original statements from each of the seven principles and select five from each principle. The criteria for selection of items was based on the reviewer's perception of which items from each principle represented instructor practices that would be observed in exemplary developmental education courses. After the selection of the items, those to be used in 
the student survey were reworded to obtain the students' perceptions (i.e., where a faculty item states I give quizzes and homework assignments, the students' survey item was rewritten to state $\underline{\text { My English instructor gives quizzes and homework assignments or My math instructor gives }}$ quizzes and homework assignments). Any survey statement with a compound predicate (i.e., I give quizzes and homework) was separated into two statements (i.e., 1. I give quizzes. 2. I give homework.). Each survey item used a five point Likert-type scale labeled very often (5), often (4), occasionally (3), rarely (2), never (1). The value range for each principle/category is demonstrated in Table 1. The survey was administered by the researcher face-to-face with students during classes. Only students who were enrolled in developmental studies courses during the fall semester of 2010 were surveyed. The surveys were administered within the final six weeks of classes.

\section{Pilot Study}

Because the researcher developed the student survey as a derivative of a survey designed for faculty, a pilot study was conducted to determine the clarity and comprehensiveness of the student survey statements. The researcher completed the Institutional Review Board process at West Virginia University and was granted "exempt" status for the pilot study research. The researcher then administered the student survey tool to students who were attending or who had attended a course in developmental English/writing or mathematics at a community college. Students were directed to take the survey via a web-based tool and to provide feedback concerning the clarity and comprehensibility of survey statements. Both the English and math versions of the survey tool were presented to students. Each survey provided areas for participants to make comments. The researcher asked students to comment on the clarity and 
comprehensibility of each survey statement. Respondents were also prompted to provide any feedback they might have to help make the survey instrument better.

A West Virginia community college provided the researcher with a total of 25 email addresses of students currently attending or who had previously attended courses in developmental math or English. A total of ten students participated in the pilot study. Two students (20\%) completed the English/writing version of the survey and eight students (80\%) completed the math version. Eight females and two males completed the surveys. Six respondents $(60 \%)$ reported being 35 to 45 years of age. Three respondents reported being 20 to 22 years of age. One respondent (10\%) reported being 23 to 25 years of age. Nine respondents $(90 \%)$ reported their racial or ethnic identification as white; one respondent $(10 \%)$ reported being African American.

Respondents were asked to rate each of the survey statements and to provide feedback in the areas provided at the end of the survey. When asked if any of the survey statements were unclear or confusing, eight respondents (80\%) answered "no;" one participant (10\%) did not respond, and one respondent (10\%) answered “no, but I didn't answer a couple of the questions because I felt they did not pertain to my math teacher" (it's noted that although this respondent stated that some questions were not answered, all of the statements in the pilot study had been responded to). When asked if survey items were written in a way that was understandable for participants, nine respondents (90\%) answered "yes" and one respondent answered "no" (this "no" response may have been a mistake on the respondent's part because in the next question when asked if you could change any statement which one would you change, the same respondent wrote "none, they were all clear"). 
When asked if the respondent could change any of the statements in this survey, which ones would they change and why, four respondents (40\%) answered "none," five of the participants (50\%) didn't respond, and one respondent (10\%) answered "under number 6 just certain questions I didn't know about my teacher." When asked if respondents had any other feedback about the survey that might help to make it better, five participants (50\%) had no response, two respondents $(20 \%)$ wrote "no," one respondent $(10 \%)$ wrote "I thought it was a good survey", one respondent (10\%) wrote "no it was a good survey," and one respondent (10\%) wrote "there should be an unsure or undecided option." Based on the overall majority feedback of pilot study participants, all of the survey statements appeared to be written clearly and were comprehensible by study participants.

\section{Data Analysis}

The purpose of this research was to determine if statistically significant differences existed between two groups in regard to their perceptions of their instructors' practices: one group of students attended developmental courses in programs that were centralized, while the other group attended developmental education courses under a decentralized structure. This research also attempted to determine if significant differences existed between instructor perceptions and student perceptions in regard to instructor practices within developmental course. In addition, this study attempted to determine if significant differences existed in instructor perceptions based on organizational types used to offer developmental courses. The survey tool for this research measured faculty and student perceptions for seven variables deemed important for improving student success in post-secondary education. Table 2 shows the survey questions used to collect data on each dependent variable. 
Table 2

DV Category and Survey Items

Dependent Variable

Survey Item

Encouraging Student/Faculty

Contact

8a: I advise my students about career opportunities in their major field.

$8 \mathrm{~b}$ : I serve as a mentor or informal advisor to students.

8c: I work with student affairs staff on issues related to student extracurricular life and life outside of school.

8d: Whenever there is a conflict on campus involving students, I try to help in its resolution.

8e: I attend events sponsored by student groups.

Encouraging Cooperation

Among Students

Encouraging Active Learning 9.a: I ask students to tell each other about their interests and backgrounds.

9.b: I ask students to evaluate each other's work.

9.c: I ask students to explain difficult ideas to each other.

9.d: I create learning communities within my class.

9.e: I create study groups within my class.

9.f: I create project teams within my class.

9.g: I distribute performance criteria to students so that each person's grade is independent of those

10.a: I ask students to relate outside events or activities to the subjects covered in the course.

10.b: I encourage students to challenge my ideas. 
Providing Prompt Feedback

Emphasizing Time on Task

Communicating High

Expectations 10.c: I encourage students to challenge the ideas of other students.

10.d: I encourage students to challenge ideas presented in readings or other course materials.

10.e: I give students concrete real-life situations to analyze.

10.f: I use simulations or role playing in my courses.

10.g: I work with students to arrange field trips related to the course.

10.h: I work with students to arrange volunteer activities related to the course.

10.i: I work with students to arrange internships related to the course.

11.a: I ask students to schedule conferences with me to discuss their progress.

11.b: I give students written comments on their strengths and weaknesses on exams and papers.

11.c: I give students a pretest at the beginning of the term to determine how much they know about the subject area.

11.d: I ask students to keep a log or record of their performance.

11.e: I call students who miss classes.

11.f: I write notes to students who miss.

12.a: I help students set challenging goals for their own learning.

12.b: I underscore the importance of regular work, steady application, sound self-pacing, and scheduling.

12.c: I explain to students the consequences of non-attendance.

12.d: I meet with students who fall behind to discuss their study habits, schedules, and other commitments.

12.e: If students miss my class I require them to make-up lost work.

13.a: I emphasize the importance of holding high standards for academic achievement.

13.b: I make clear my expectations orally at the beginning of each course. 
13.c: I make clear my expectation in writing at the beginning of each course.

13.d: I help students set challenging goals for their own learning.

13.e: I explain to students what will happen if they do not complete their work on time.

13.f: I periodically discuss how well the class is doing during the course of the semester.

Respecting Diverse Talents and Ways of Learning 14.a: I encourage students to speak up when they don't understand.

14.b: I discourage snide remarks, sarcasm, kidding, and other class behaviors that may embarrass students.

14.c: I use diverse teaching activities to address a broad spectrum of students.

14.d: I select readings and designs activities related to the backgrounds of his/her students.

14.e: I try to find out about my students' learning styles at the beginning of each course.

14.f: I try to find out about my students' interests at the beginning of each course.

14.g: I try to find out about my students' backgrounds at the beginning of each course. 
The analysis of research questions in this study was conducted using a multivariate analysis of variance (MANOVA) to determine if differences existed between each group. If the MANOVA demonstrated an overall significant difference between groups ( $\operatorname{sig} . p<.05$ ), a 2group analysis of variance (ANOVA) was conducted on the seven dependent variables (7 Principles for Good Practice in Undergraduate Education) to determine if a statistically significant difference existed between group means (see Table 3). In addition, descriptive statistics were used to examine where groups did not differ on research questions one, two, and four.

Table 3

Research Questions and Statistical Tests Research Question Statistical Test

RQ1: Are there statistically significant differences between the perceptions of students attending centralized developmental education programs and students attending decentralized developmental education programs regarding the 7 Principles for Good Practice in Undergraduate Education?

Multivariate Analysis of Variance (MANOVA). If MANOVA sig. $p<.05$ followup subtest will be 2 group ANOVA on each $D V$

Multivariate Analysis of Variance (MANOVA). If MANOVA sig. $p<.05$ followup subtest will be 2 group ANOVA on each DV

Multivariate Analysis of Variance (MANOVA). If MANOVA sig. $p<.05$ followup subtest will be 2 group ANOVA on each DV

RQ4: Are there statistically significant differences between the perceptions of instructors teaching in developmental English/writing courses and instructors teaching in developmental mathematics courses regarding their use of the 7 Principles for Good Practice in Undergraduate Education?
Multivariate Analysis of Variance (MANOVA). If MANOVA sig. $p<.05$ followup subtest will be 2 group ANOVA on each DV 


\section{Limitations of the Study}

One major limitation of the current study is the small sample sizes. This study only surveyed students attending six community colleges in the Appalachian region, only four of which were used to answer Research Question 1. The results of this study cannot be generalized to the greater population of community colleges in the Appalachian region. This study is also affected by the researcher's limited investigation into how well each of the four schools (used for Research Question 1) met the conditions of being centralized or decentralized. In essence, in order to determine the organizational model used to offer developmental courses, the researcher used a survey that allowed the schools to self-report the model used. No real qualitative data were collected to legitimize the model used by each school nor determine the level of orthodoxy these schools adhered to when meeting the definitions of centralized and decentralized models as prescribed in this study. In addition, this study uses an adjusted version of the 7 Principles for Good Practice (1989) survey which excludes 35 of the original statements, perhaps limiting the power of the survey. Further limitation is noted in the fact that this is a quantitative study that utilizes a survey tool with predetermined statements that are limited in their ability to provide information about classroom practices; in effect, the survey was limited in scope to the activities measured through each statement and did not measure other activities and behaviors that may have taken place within the classroom that may have aligned with certain principles. A richer, more dynamic study might include a qualitative component to allow the researcher to gain deeper insight into student and instructor experiences. 


\section{Summary}

Chapter Three provided an overview of the research methodology proposed to address the research questions established in Chapter One. Chapter Three outlined the research questions, population, sample and sampling procedures, and the methods for data collection and data analysis. This chapter also provided a description of the proposed pilot study to be conducted prior to the actual research. This study proposed to survey students and faculty members in developmental education courses in six public Appalachian community colleges to determine if differences existed in their perceptions regarding the seven principles for good practice as developed by Chickering et al. (1989). Surveys were administered to students and faculty in developmental education courses during the last 6 weeks of the 2010 fall semester. 


\section{Chapter Four:}

\section{Presentation and Analysis of Data}

\section{Overview}

Chapter Four provides a detailed analysis of the survey results. First, an overview of the research population and samples are discussed. Second, demographic information about the study participants is reviewed. Finally, an analysis of data is provided regarding each of the four research questions. Research Question 1 examined differences between centralized and decentralized groups. Research Question 2 examined differences between the perceptions of students and instructors regarding classroom practices. Research Question 3 examined differences between students attending developmental math and students attending developmental English courses in regard to their perceptions of instructional practices. Finally, Research Question 4 examined the differences between developmental math and developmental English instructors' perceptions of their own practices.

\section{Population and Sample}

Six community colleges in the Appalachian region were selected to participate in this study (Table 4). Each of these schools was categorized by the Carnegie classification system as small, two-year, exclusively associate's degree granting schools. There were 2,965 students registered for developmental math and English courses in the fall 2010 semester between the selected six schools. There were approximately 68 instructors teaching in these programs. Table 4 provides a breakdown of the number of students who participated in this research study in both math and English courses for each of the six schools selected. 
Table 4

Breakdown of participants by school

\begin{tabular}{|c|c|c|c|}
\hline Schools & Math & English & $N$ \\
\hline $\mathrm{OHCC}^{*}$ & 254 & 144 & 398 \\
\hline KYCC* & 133 & 68 & 201 \\
\hline WVCC & 116 & 88 & 204 \\
\hline $\mathrm{VACC} 1 * *$ & 43 & 38 & 81 \\
\hline $\mathrm{VACC} 2 * *$ & 30 & 50 & 80 \\
\hline VACC3 & 62 & 51 & 113 \\
\hline Total & 638 & 439 & 1077 \\
\hline
\end{tabular}

*Centralized Group

**Decentralized group

The researcher sent a survey via email to over 70 community colleges located in the Appalachian region at the beginning of the fall 2010 semester to determine the organizational structure used to offer developmental education courses. The researcher used this survey to classify prospective participating institutions as either offering developmental courses through a centralized or decentralized structure. Two of the schools selected for this study (OHCC and KYCC) self-reported using a centralized structure. Two other schools selected for this study (VACC1 and VACC2) self-reported using a decentralized structure to offer developmental education courses. OHCC, KYCC, VACC1, and VACC2, were utilized to address Research Question 1. All six schools were used to address the remaining research questions. One community college was located in Ohio, one school was located in Kentucky, three schools were located in Virginia, and one school was located in West Virginia.

The researcher visited all six community colleges during the final weeks of the fall 2010 semester and administered the survey face-to-face to students and instructors. The researcher was able to use 1,077 surveys for this research project. There were 18 students who declined to participate in this study, and 13 surveys were discarded as incomplete for a total response rate of 97\%. Thirty-six percent of the total student population registered for developmental courses 
during the fall 2010 semester was present to participate in this research study. This research focused only on students attending on-campus developmental math and English/writing courses.

\section{Demographic Data}

Eight participants $(0.7 \%)$ in this study reported their racial identity or ethnicity as Native American. Six participants (0.6\%) reported being Asian or Pacific Islander. There were 89 participants (8\%) who reported their racial identity or ethnicity as black or African American. Eight participants $(0.7 \%)$ reported being Hispanic or Latino. There were 912 participants $(85 \%)$ who reported their racial identity or ethnicity as White. There were 40 participants (4\%) who reported having a racial identity as something other than those listed. In addition, there were 14 participants $(1 \%)$ who did not report their racial or ethnic identity. Table 5 provides an overview of the racial or ethnic identity of student participants.

Table 5

Breakdown of participants by race

\begin{tabular}{lcc}
\hline Race or Ethnicity & $N$ & $\%$ \\
\hline Native American & 8 & $.7 \%$ \\
Asian or Pacific & & \\
Islander & 6 & $.6 \%$ \\
Black, African & & \\
American & 89 & $8 \%$ \\
Hispanic, Latino & 8 & $.7 \%$ \\
White & 912 & $85 \%$ \\
Other & 40 & $4 \%$ \\
No Response & 14 & $1 \%$ \\
Total & 1077 & $100 \%$ \\
\hline
\end{tabular}

The majority of students who participated in this study, 469 participants (44\%), reported being 18 to 19 years old. The second largest group of students, 163 participants (15\%), reported being 20 to 22 years old. There were 92 students (9\%) who reported being 23 to 25 years old. In addition, there were 104 participants (10\%) who reported being 26 to 30 years old. The smallest group of students surveyed, 53 participants (5\%), reported being 31 to 35 years old. There were 
112 participants $(10 \%)$ who reported being 36 to 45 years old, and 79 participants $(6.5 \%)$ reported being 46 years old or older. Five participants $(0.5 \%)$ didn't report their age. Table 6 provides an overview of the reported ages of all student participants in this study.

Table 6 Breakdown of participants by age

\begin{tabular}{lcc}
\hline Age & $N$ & $\%$ \\
\hline $18-19$ & 469 & $44 \%$ \\
$20-22$ & 163 & $15 \%$ \\
$23-25$ & 92 & $9 \%$ \\
$26-30$ & 104 & $10 \%$ \\
$31-35$ & 53 & $5 \%$ \\
$36-45$ & 112 & $10 \%$ \\
$46-O 1 d e r$ & 79 & $6.5 \%$ \\
Didn't & & \\
Report & 5 & $.5 \%$ \\
Total & 1077 & $100 \%$ \\
\hline
\end{tabular}

There were 684 female (64\%) participants in this study and 392 participants (36\%) who reported their gender as male (Table 7). There were 29 out of the possible 68 instructors who participated in this study for a $42 \%$ response rate of instructors. Sixteen instructors were female, and 13 were male. Two instructors reported having doctoral degrees, 20 held master's degrees, and seven held bachelor's degrees.

Table 7

Breakdown of participants by gender

\begin{tabular}{lcc}
\hline Gender & $N$ & $\%$ \\
\hline Female & 684 & $64 \%$ \\
Male & 392 & $36 \%$ \\
Total & 1077 & $100 \%$ \\
\hline
\end{tabular}




\section{Data Analysis}

For this study, each research question was analyzed using a two-group multivariate analysis of variance. When the MANOVA demonstrated a significant finding $(p<.05)$, subsequent two-group ANOVAs were conducted to determine the differences between specific principles and then to determine where groups differed on each survey statement. To analyze principles, each respondent's answers were summed for each statement in that particular category. Table 1 in Chapter Three outlines the scale value for principles and statements based on this process. For instance, when examining Principle 1, the point value ranges from 5 to 25 , because there are five statements $(5=$ never $\ldots 25=$ very often $)$. Principle 2 has a range of $7-$ $35(7=$ never $\ldots 35=$ very often $)$, because there are seven statements in that category. Each statement, however, is rated on a $1-5$ Likert-type scale where $1=$ never, $2=$ rarely, $3=$ occasionally, 4 = often, and $5=$ very often. When comparing survey statements, the researcher examined the group average for each statement in a particular category. To offset the effects of unequal sample sizes, a Type III Sums of Squares was used in SPSS to appropriately weight the uneven cell sizes.

To provide further insight into Research Questions 1, 2, and 4, the researcher has also provided an overview of how each group compared on the survey statements where no significant differences were detected. An examination of the statements where the groups did not differ statistically provides a broader picture of areas where these groups agreed on strengths and weaknesses in the practices outlined in the survey. Although it is important to note where these groups differed, it is equally important to determine where they did not differ in their perceptions of practices occurring within the classroom. 


\section{Research Question 1}

The first research question asked if there were statistically significant differences between the perceptions of students attending centralized developmental education programs and students attending decentralized developmental education programs regarding the 7 Principles for Good Practice. Analysis of Research Question 1 determined that statistical differences existed between the two groups on five of the seven principles. To address this research question, four community colleges were selected based on their responses to the Developmental Education Organizational Structure (DEOS) survey developed by the researcher (see Appendix A). Two of the colleges (VACC1 and VACC2) self-reported offering developmental education courses using a decentralized model while the other two schools (OHCC and KYCC) self-reported using a centralized model to offer developmental education courses. The researcher visited each of these community colleges during the final weeks of courses of the fall 2010 semester and administered the adjusted version of the seven principles survey to 760 students face-to-face. There were 599 surveys completed by students at schools utilizing a centralized structure and 161 surveys completed by students attending schools utilizing a decentralized structure. The researcher used an adjusted version of the 7 Principles for Good Practice survey that provided respondents with a Likert-type scale $(5=$ very often, $4=$ often, $3=$ occasionally, $2=$ rarely, and $1=$ never $)$.

A two-group multivariate analysis of variance (MANOVA) was conducted to determine if differences existed overall between the mean scores of students attending centralized schools and students attending decentralized schools regarding their responses to the adjusted 7 Principles for Good Practice in Undergraduate Survey (see Appendices F, G, and H). The MANOVA yielded a score of $F(7,752)=17.158, p<.001$, demonstrating an overall significant difference between groups in regard to the seven dependent variables. A subsequent analysis of variance was performed on each of the seven dependent variables which demonstrated a 
significant difference between centralized and decentralized schools on five of the seven principles (Table 8 ).

Table 8

ANOVA results for each dependent variable where students differed in RQ1

Principles $\quad$ Decentral Central

$\begin{array}{lllllllll}N & M & S D & N & M & S D & F(d f) & \text { Sig. }\end{array}$

Principle 1

Good Practice

Encourages Student-

Faculty Contact

$\begin{array}{lllllll}161 & 15.48 & 4.27 & 599 & 14.57 & 5.43 & 3.87 \\ (1,759)\end{array}$

.049

Principle 2

Good Practice

Encourages

Cooperation Among

Students

$\begin{array}{llllllll}161 & 18.89 & 6.97 & 599 & 22.04 & 7.40 & 23.52(1,759) & .000\end{array}$

Principle 3

Good Practice

Encourages Active

Learning

$\begin{array}{llllllll}161 & 25.70 & 6.93 & 599 & 23.88 & 8.27 & 6.53(1,759) & .011\end{array}$

*Principle 4

Good Practice

$\begin{array}{lllllllll}\text { Encourages Feedback } & 161 & 16.41 & 5.39 & 599 & 16.74 & 5.52 & .466(1,759) & .495\end{array}$

Principle 5

Good Practice

Emphasizes Time on

Task

$\begin{array}{llllllll}161 & 18.13 & 4.36 & 599 & 16.98 & 4.89 & 7.31(1,759) & .007\end{array}$

Principle 6

Good Practice High

Expectations

$\begin{array}{llllllll}161 & 24.65 & 4.77 & 599 & 22.80 & 6.03 & 13.03(1,759) & .000\end{array}$

*Principle 7

Good Practice

Respects Diverse

Talents and Ways of

Learning

$161 \quad 24.93$

$\begin{array}{lll}6.14 & 599 \quad 25.03\end{array}$

$6.89 \quad .025(1,759)$

.875

* No significant difference between groups 
Further analyses (ANOVA's) demonstrated that the centralized group differed from the decentralized group on 23 of the 45 statements presented in the adjusted 7 Principles for Good Practice Survey. Table 9 highlights a comparison of the centralized and decentralized groups, highlighting the mean score, standard deviation, $F$ score, and significance for each statement. The decentralized group demonstrated higher mean scores on 15 of the 23 statements where differences were detected. The centralized group scored higher on the remaining eight statements, including five of the statements presented in Principle 2 (Good Practice Encourages Cooperation Among Students). 
Table 9

ANOVA results for each survey statement where students differed regarding RQ1

Principle Statements

Decentral Central

Principle 1: Student-Faculty Contact

a. advises students about career opportunities.

$N \quad M$

$S D$

$N$

$M$

$S D \quad F(d f)$

$P$

b. serves as mentor or informal advisor.

$161 \quad 3.21 \quad 1.21$

$599 \quad 2.81 \quad 1.30 \quad 11.89(1,759)$

.001

$\begin{array}{lllllll}161 & 3.95 & 1.00 & 599 & 3.59 & 1.29 & 10.6(1,759)\end{array}$

.001

Principle 2: Cooperation Among Students

b. asks students to evaluate each others work.

c. asks students to explain difficult ideas to each other.

$161 \quad 2.42$

1.35

599

2.96

1.48

$17.31(1,759)$

.000

$\begin{array}{llllllll}161 & 2.82 & 1.43 & 599 & 3.15 & 1.31 & 7.56(1,759) & .006\end{array}$

e. creates study groups.

$161 \quad 2.36 \quad 1.36$

$161 \quad 2.11 \quad 1.27$

f. creates project teams.

$\begin{array}{lll}161 & 2.95 \quad 1.48\end{array}$

$1.36 \quad 599-200$

g. distributes performance criteria.

Principle 3: Active Learning

a. asks students to relate outside events.

b. encourages students to challenge his/her ideas

$161 \quad 3.35$

3.35

1.28

599

3.00

$1.348 .95(1,759)$

$\begin{array}{llll}599 & 3.68 & 1.23 & 7.36 \\ (1,759)\end{array}$

.003

e. gives students concrete real-life situations to

16

$61 \quad 3.91$

1.09

599

$3.38 \quad 1.3 \quad 22.06(1,759)$

.000 
Principle 4: Prompt Feedback

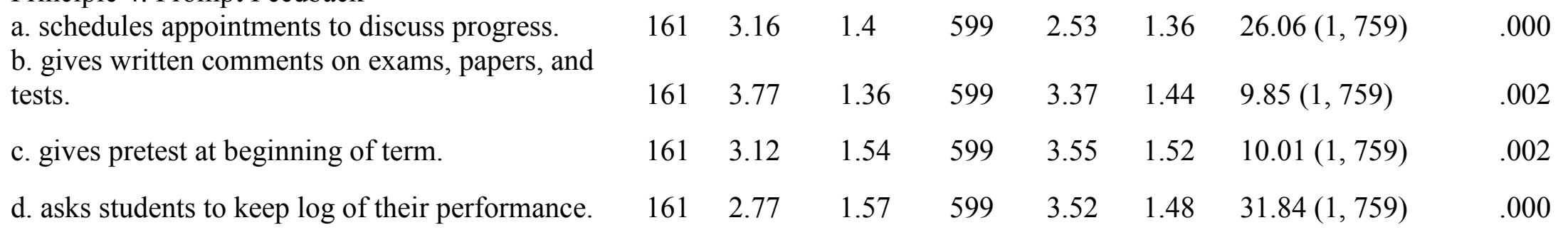

Principle 5: Time on Task

a. helps students set challenging goals for learning.

c. explains consequences of non-attendance.

$161 \quad 3.67$

$161 \quad 3.24$

1.27

599

3.25

1.33

$12.77(1,759)$

.000

d. meets with students who fall behind to discuss study habits.

16

$161 \quad 3.47$

1.36

599

3.03

1.44

$9.55(1,759)$

.002

Principle 6: High Expectations

\begin{tabular}{|c|c|c|c|c|c|c|c|c|}
\hline a. emphasizes importance of high standards. & 161 & 4.22 & 0.93 & 599 & 3.82 & 1.2 & $15.55(1,759)$ & .000 \\
\hline b. makes expectations clear orally at beginning. & 161 & 4.42 & 0.84 & 599 & 4.09 & 1.09 & $12.39(1,759)$ & .000 \\
\hline c. makes clear expectations in writing. & 161 & 4.13 & 1.19 & 599 & 3.84 & 1.30 & $6.38(1,759)$ & .012 \\
\hline d. helps students set challenging goals. & 161 & 3.90 & 1.2 & 599 & 3.50 & 1.37 & $11.13(1,759)$ & .001 \\
\hline $\begin{array}{l}\text { completed on time. } \\
\text { complon work }\end{array}$ & 161 & 4.21 & 1.01 & 599 & 3.85 & 1.21 & $11.76(1,759)$ & .001 \\
\hline
\end{tabular}

Principle 7: Diverse Talents and Ways of Learning g. tries to find out about students' backgrounds. $161 \quad 3.00$ 1.46 599 3.26 1.44 
To provide additional information regarding Research Question 1, Table 10 provides the cumulative averages for both decentralized and centralized students in regard to statements in each of the seven principles where the two groups did not demonstrate a significant difference in their responses. It's notable that students rated instructors lowest in the area of prompt feedback $($ mean $=1.83)$. The second lowest area where students rated instructors was encouraging active learning $($ mean $=2.35)$. The third lowest area rated by students was student-faculty contact $($ mean $=2.74)$.

Table 10

Cumulative averages of survey statements where groups do not differ by principle for RQ1

\begin{tabular}{|c|c|c|}
\hline Principle & $N$ & $M$ \\
\hline Principle 1 Good Practice Encourages Student-Faculty Contact & 760 & 2.74 \\
\hline Principle 2 Good Practice Encourages Cooperation Among Students & 760 & 3.16 \\
\hline Principle 3 Good Practice Encourages Active Learning & 760 & 2.35 \\
\hline Principle 4 Good Practice Gives Prompt Feedback & 760 & 1.83 \\
\hline Principle 5 Good Practice Emphasizes Time on Task & 760 & 3.43 \\
\hline Principle 6 Good Practice Communicates High Expectations & 760 & 3.71 \\
\hline $\begin{array}{l}\text { Principle } 7 \text { Good Practice Respects Diverse Talents and Ways of } \\
\text { Learning }\end{array}$ & 760 & 3.63 \\
\hline
\end{tabular}

Table 11 provides a breakdown of the statements where decentralized and centralized students did not differ statistically in their responses. Although Research Question 1 was concerned with the differences between groups, Tables 10 and 11 provide more insight into areas where these groups did not differ in their perceptions regarding instructor practices. 
Table 11

Mean scores on statements where groups did not differ for RQ1

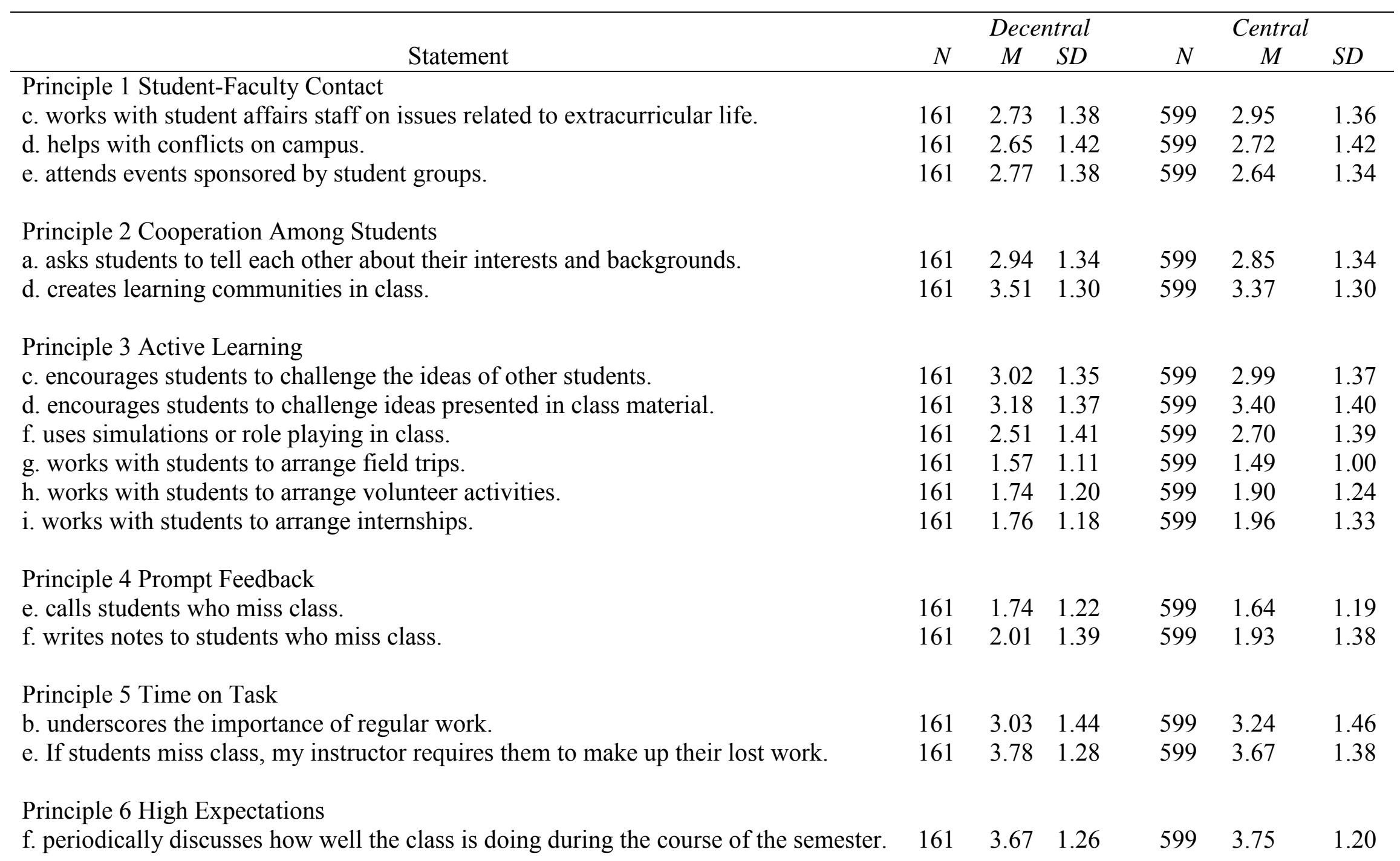


Principle 7 Diverse Ways of Learning

a. encourages students to speak up when they don't understand.

$\begin{array}{lllll}161 & 4.46 & .88 & 599 & 4.52\end{array}$

b. discourages snide remarks, sarcasm, kidding, and behaviors that embarrass others.

c. uses diverse teaching activities to address a broad spectrum of students.

$\begin{array}{lll}161 & 3.81 & 1.35\end{array}$

$\begin{array}{lll}161 & 3.64 & 1.29\end{array}$

$599 \quad 3.70$

d. selects readings and designs activities related to students' backgrounds.

$161 \quad 2.84 \quad 1.44$

e. tries to find out about his/her students' learning styles at the beginning of the course.

$\begin{array}{lll}161 & 3.43 & 1.39\end{array}$

f. tries to find out about his/her students' interests at the beginning of the course.

$\begin{array}{lll}161 & 3.55 & 1.37\end{array}$ 


\section{Research Question 2}

Research question 2 asked if there were statistically significant differences between developmental students' perceptions and developmental instructors' perceptions in regard to the 7 Principles for Good Practice in Undergraduate Education. Analysis of Research Question 2 determined that statistical differences existed between the two groups on five of the seven principles. To address this research question, the researcher used all of the survey data collected from the six community colleges sampled. All 29 instructor responses were used to address this question. A random sample of 283 student responses was selected from the original 1,077 student responses. A sample calculator was used to determine that 283 responses would provide a sample with a 95\% confidence level and 5\% confidence interval relative to the original 1,077 responses. In essence, the 283 random survey responses selected from the 1,077 provided the minimum number of responses to be used in comparison against the low number of instructor responses, ensuring that the researcher could be confident $95 \%$ of the time that the mean scores calculated for each student response would be accurate within a plus or minus $5 \%$ window to the original 1,077 responses. The survey instrument uses a Likert-type scale (5-very often, 4-often, 3occasionally, 2-rarely, 1-never).

A two-group multivariate analysis of variance (MANOVA) was conducted to determine if differences existed between the mean scores of students attending developmental courses and instructors regarding their responses to the adjusted 7 Principles for Good Practice Survey. The MANOVA yielded a score of $F(7,304)=12.344, p<.001$ demonstrating a significant difference between groups in regard to the seven dependent variables. A subsequent analysis of variance on each of the dependent variables demonstrated a significant difference between students' and instructors' responses on five of the seven principles (Table 12). 
Table 12

ANOVA results for each dependent variable where groups differed for RQ2

\begin{tabular}{|c|c|c|c|c|c|c|c|c|}
\hline \multirow[t]{2}{*}{ Principle } & \multicolumn{3}{|c|}{ Student } & \multicolumn{3}{|c|}{ Teacher } & \multirow[b]{2}{*}{$F(d f)$} & \multirow[b]{2}{*}{ Sig. } \\
\hline & $N$ & & $S D$ & $N$ & & $S D$ & & \\
\hline \multicolumn{9}{|l|}{ Principle 1} \\
\hline Good Practice Encourages & & & & & & & & \\
\hline $\begin{array}{l}\text { Student-Faculty Contact } \\
\text { *Principle } 2\end{array}$ & 283 & 15.44 & 5.36 & 29 & 11.93 & 4.43 & $11.59(1,311)$ & .000 \\
\hline \multicolumn{9}{|l|}{ Good Practice Encourages } \\
\hline Cooperation Among & & & & & & & & \\
\hline \multicolumn{9}{|l|}{ *Principle 3} \\
\hline \multicolumn{9}{|l|}{ Good Practice Encourages } \\
\hline $\begin{array}{l}\text { Active Learning } \\
\text { Principle } 4\end{array}$ & 283 & \multicolumn{6}{|c|}{ Principle 4} & .404 \\
\hline \multicolumn{9}{|l|}{ Good Practice Gives } \\
\hline $\begin{array}{l}\text { Prompt Feedback } \\
\text { Principle } 5\end{array}$ & 283 & 16.93 & 5.56 & 29 & 20.10 & 5.31 & $8.61(1,311)$ & .002 \\
\hline \multicolumn{9}{|l|}{ Good Practice Emphasizes } \\
\hline Time on Task & 283 & 17.77 & 4.47 & 29 & 21.13 & 3.05 & $15.57(1,311)$ & .000 \\
\hline \multicolumn{9}{|l|}{ Principle 6} \\
\hline \multicolumn{9}{|l|}{ Good Practice } \\
\hline Expectations & 283 & 23.85 & 5.32 & 29 & 26.26 & 3.14 & $9.55(1,311)$ & .002 \\
\hline Principle 7 & & & & & & & & \\
\hline Good Practice Respects & & & & & & & & \\
\hline $\begin{array}{l}\text { Diverse Talents and Ways } \\
\text { of Learning }\end{array}$ & 283 & 25.00 & 6.81 & 29 & 28.82 & 5.31 & $8.58(1,311)$ & .004 \\
\hline
\end{tabular}

* No significant difference between groups

Further analyses (ANOVA's) demonstrated a difference between groups on 20 of the 45 survey statements. Students rated their instructors higher on five of the survey statements, including areas that encourage student-faculty contact and areas that encourage active learning; more specifically, students rated instructors higher in regard to serving as a mentor or informal advisor, working with student affairs staff on issues related to extracurricular life, helping with conflicts on campus, working with students to arrange volunteer activities, and working with 
students to arrange internships. Instructors rated themselves higher on the remaining 15 survey statements. Table 13 highlights a comparison of students and instructors, highlighting the mean score, standard deviation, $F$ score, and significance for each statement. 
Table 13

ANOVA results for each survey statement where groups differed regarding RQ2

\begin{tabular}{|c|c|c|c|c|c|c|c|c|}
\hline \multirow[t]{2}{*}{ Statement } & \multicolumn{3}{|c|}{ Student } & \multicolumn{3}{|c|}{ Teacher } & \multirow[b]{2}{*}{$F$} & \multirow[b]{2}{*}{$P$} \\
\hline & $N$ & $M$ & $S D$ & $N$ & $M$ & $S D$ & & \\
\hline Principle 1: Student-Faculty Contact & & & & & & & & \\
\hline b. serves as a mentor or informal advisor. & 283 & 3.86 & 1.18 & 29 & 3.00 & 1.19 & $14.06(1,310)$ & .000 \\
\hline & 202 & 201 & 0 & 0 & 175 & 08 & & 000 \\
\hline $\begin{array}{l}\text { extracurricular life. } \\
\text { d. helps with conflicts on campus. }\end{array}$ & $\begin{array}{l}283 \\
283\end{array}$ & $\begin{array}{l}3.01 \\
2.81\end{array}$ & $\begin{array}{l}1.40 \\
1.49\end{array}$ & $\begin{array}{l}29 \\
29\end{array}$ & $\begin{array}{l}1.15 \\
2.17\end{array}$ & $\begin{array}{l}.98 \\
1.16\end{array}$ & $\begin{array}{c}22.02(1,310) \\
5.13(1.310)\end{array}$ & .000 \\
\hline \multicolumn{9}{|l|}{ Principle 2: Cooperation Among Students } \\
\hline $\begin{array}{l}\text { a. asks students to tell each other about interests and } \\
\text { background. }\end{array}$ & 283 & 2.92 & 1.37 & 29 & 3.51 & 1.32 & $4.92(1,310)$ & .027 \\
\hline c. asks students to explain difficult ideas to each other. & 283 & 3.11 & 1.36 & 29 & 3.79 & .81 & $6.89(1,310)$ & .009 \\
\hline \multicolumn{9}{|l|}{ Principle 3: Active Learning } \\
\hline h. works with students to arrange volunteer activities. & 283 & 1.89 & 1.31 & 29 & 1.31 & .66 & $5.66(1,310)$ & .018 \\
\hline i. works with students to arrange internships. & 283 & 1.90 & 1.33 & 29 & 1.20 & .49 & $7.82(1,310)$ & .005 \\
\hline \multicolumn{9}{|l|}{ Principle 4: Prompt Feedback } \\
\hline e. calls students who miss class. & 283 & 1.85 & 1.29 & 29 & 2.41 & 1.26 & $4.87(1,310)$ & .028 \\
\hline f. writes notes to students who miss class. & 283 & 2.19 & 1.47 & 29 & 3.20 & 1.29 & $12.72(1,310)$ & .000 \\
\hline \multicolumn{9}{|l|}{ Principle 5: Time on Task } \\
\hline b. underscores the importance of regular work. & 283 & 3.19 & 1.45 & 29 & 4.62 & .67 & $27.05(1,310)$ & .000 \\
\hline c. explains to students the consequences of non-attendance. & 283 & 4.07 & 1.06 & 29 & 4.65 & .72 & $8.36(1,310)$ & .004 \\
\hline $\begin{array}{l}\text { e. If students miss class, my instructor requires them to make up } \\
\text { their lost work. }\end{array}$ & 283 & 3.80 & 1.32 & 29 & 4.55 & .73 & $8.94(1,310)$ & .003 \\
\hline \multicolumn{9}{|l|}{ Principle 6: High Expectations } \\
\hline a. emphasizes the importance of holding high standards. & 283 & 4.06 & 1.09 & 29 & 4.51 & .78 & $4.64(1,310)$ & .032 \\
\hline b. makes clear his/her expectations orally at the beginning of & 283 & 4.29 & .92 & 29 & 4.86 & .44 & $3.94(1,310)$ & .048 \\
\hline
\end{tabular}


each course.

c. makes clear his/her expectations in writing at the beginning of each course.

\begin{tabular}{llllllll}
283 & 3.98 & 1.25 & 29 & 4.75 & .51 & $10.66(1,310)$ & .001 \\
283 & 4.10 & 1.13 & 29 & 4.68 & .54 & $7.52(1,310)$ & .006 \\
283 & 3.73 & 1.23 & 29 & 4.20 & .90 & $3.94(1,310)$ & .048 \\
& & & & & & & \\
283 & 3.75 & 1.47 & 30 & 4.51 & .73 & $7.46(1,310)$ & .007 \\
283 & 3.47 & 1.43 & 30 & 4.31 & 1.03 & $9.81(1,310)$ & .002 \\
283 & 3.13 & 1.49 & 30 & 4.06 & 1.22 & $10.74(1,310)$ & .001 \\
\hline
\end{tabular}

b. discourages snide remarks, sarcasm, kidding, and behaviors that embarrass others.

f. tries to find out about his/her students' interests at the beginning of the course.

g. tries to find out about his/her students' backgrounds at the beginning of the course. their work on time. their work on time.

f. periodically discusses how well the class is doing. 
To provide additional information regarding Research Question 2, Table 14 shows the combined averages for both students and instructors in regard to statements in each of the seven principles where the two groups did not demonstrate a significant difference in their responses. It's notable the lowest average is found in student-faculty contact (mean $=2.68)$. The highest averages between groups was found in Principle 7 (mean $=3.81)$.

Table 14

Combined averages on survey statements where instructors did not differ by principle for RQ2

\begin{tabular}{lcc}
\hline \multicolumn{1}{c}{ Principle } & $N$ & $M$ \\
\hline Principle 1 Good Practice Encourages Student-Faculty Contact & 312 & 2.68 \\
Principle 2 Good Practice Encourages Cooperation Among Students & 312 & 3.13 \\
Principle 3 Good Practice Encourages Active Learning & 312 & 3.10 \\
Principle 4 Good Practice Gives Prompt Feedback & 312 & 3.41 \\
Principle 5 Good Practice Emphasizes Time on Task & 312 & 3.49 \\
Principle 6 Good Practice Communicates High Expectations & 312 & 3.79 \\
Principle 7 Good Practice Respects Diverse Talents and Ways of Learning & 312 & 3.81 \\
\hline
\end{tabular}

Table 15 provides a breakdown of the statements where students and instructors did not differ statistically in their responses. Although Research Question 2 was concerned with the differences between groups, Tables 14 and 15 provide more insight into areas where these groups did not differ in their perceptions regarding instructor practices. 


\section{Table 15}

Mean scores on statements where groups did not differ for RQ2

\begin{tabular}{|c|c|c|c|c|c|c|}
\hline \multirow{2}{*}{$\begin{array}{ll} & \text { Statement }\end{array}$} & \multicolumn{3}{|c|}{ Student } & \multicolumn{3}{|c|}{ Teacher } \\
\hline & $N$ & $M$ & $S D$ & $N$ & $M$ & $S D$ \\
\hline \multicolumn{7}{|l|}{ Principle 1: Student-Faculty Contact } \\
\hline a. advises students about career opportunities. & 283 & 2.96 & 1.36 & 29 & 2.55 & 1.21 \\
\hline e. attends events sponsored by student groups. & 283 & 2.77 & 1.41 & 29 & 2.44 & .98 \\
\hline \multicolumn{7}{|l|}{ Principle 2: Cooperation Among Students } \\
\hline b. asks students to evaluate each others work. & 283 & 3.04 & 1.52 & 29 & 3.00 & 1.53 \\
\hline d. creates learning communities in class. & 283 & 3.60 & 1.31 & 29 & 3.41 & 1.35 \\
\hline e. creates study groups in class. & 283 & 3.01 & 1.50 & 29 & 3.00 & 1.13 \\
\hline f. creates project teams in class. & 283 & 2.61 & 1.50 & 29 & 2.55 & 1.42 \\
\hline g. distributes performance criteria to students. & 283 & 3.33 & 1.48 & 29 & 3.82 & 1.62 \\
\hline \multicolumn{7}{|l|}{ Principle 3: Active Learning } \\
\hline a. asks students to relate outside events or activities to subjects covered. & 283 & 3.29 & 1.40 & 29 & 3.55 & 1.02 \\
\hline b. encourages students to challenge his/her ideas. & 283 & 3.91 & 1.20 & 29 & 3.58 & 1.05 \\
\hline c. encourages students to challenge the ideas of other students. & 283 & 3.13 & 1.33 & 29 & 3.51 & 1.18 \\
\hline d. encourages students to challenge ideas presented in class material. & 283 & 3.36 & 1.34 & 29 & 3.20 & 1.29 \\
\hline e. gives students concrete real-life situations to analyze. & 283 & 3.72 & 1.29 & 29 & 3.96 & .90 \\
\hline f. uses simulations or role playing in class. & 283 & 2.59 & 1.48 & 29 & 2.48 & 1.08 \\
\hline g. works with students to arrange field trips. & 283 & 1.77 & 1.34 & 29 & 1.41 & .98 \\
\hline $\begin{array}{l}\text { Principle 4: Prompt Feedback } \\
\text { a. asks students to schedule conferences to discuss progress. }\end{array}$ & 283 & 2.91 & 1.40 & 29 & 3.03 & 1.20 \\
\hline
\end{tabular}


b. gives students written comments on their strengths and weaknesses.

c. gives students a pretest at the beginning of the term.

Principle 5: Time on Task

a. helps students set challenging goals for their own learning.

\section{Principle 6: High Expectations}

d. helps students set challenging goals for their own learning.

Principle 7: Diverse Ways of Learning

a. encourages students to speak up when they don't understand. 283

c. uses diverse teaching activities to address a broad spectrum of students.

d. selects readings and designs activities related to students' backgrounds.

e. tries to find out about his/her students' learning styles at the beginning of the course. 


\section{Research Question 3}

Research Question 3 asked if there were statistically significant differences between developmental math students' perceptions and developmental English/writing students' perceptions in regard to the 7 Principles for Good Practice. Analysis of Research Question 3 determined that statistical differences existed between the two groups on all seven principles. To address this research question, the researcher used all of the survey data collected from six community colleges, including WVCC, VACC1, VACC2, VACC3, OHCC, and KYCC. As shown in Table 4, 638 math student responses and 439 English student responses were compared. The survey instrument used a Likert-type scale $(5=$ very often, $4=$ often, $3=$ occasionally, 2 = rarely, and $1=$ never $)$.

A two-group multivariate analysis of variance (MANOVA) was conducted to determine if differences existed between the mean scores of students attending developmental English courses and students attending developmental math courses regarding their responses to the adjusted 7 Principles for Good Practice Survey. The MANOVA yielded a score of $F(7,1069)=$ $34.175, p<.001$, demonstrating a significant difference between groups in regard to the seven dependent variables. A subsequent analysis of variance on each dependent variable demonstrated a significant difference between math and English students' mean scores on all seven principles for good practice, with the English group demonstrating higher averages on all seven principles (see Table 16). 
Table 16

ANOVA results for each dependent variable for RQ3

\begin{tabular}{|c|c|c|c|c|c|c|c|c|}
\hline \multirow[t]{2}{*}{ Principle } & \multicolumn{3}{|c|}{ English } & \multicolumn{3}{|c|}{ Math } & \multirow[b]{2}{*}{$F(d f)$} & \multirow[b]{2}{*}{ Sig. } \\
\hline & $N$ & $M$ & $S D$ & $N$ & $M$ & $S D$ & & \\
\hline \multicolumn{9}{|l|}{ Principle 1} \\
\hline $\begin{array}{l}\text { Good Practice Encourages Student-Faculty } \\
\text { Contact }\end{array}$ & 439 & 15.72 & 5.03 & 638 & 14.08 & 5.36 & $27.80(1,1075)$ & .000 \\
\hline Principle 2 & & & & & & & & \\
\hline Good Practice Encourages Cooperation & & & & & & & & \\
\hline $\begin{array}{l}\text { Among Students } \\
\text { Principle } 3\end{array}$ & 439 & 24.71 & 6.23 & 638 & 18.57 & 7.46 & $201.28(1,1075)$ & .000 \\
\hline $\begin{array}{l}\text { Good Practice Encourages Active Learning } \\
\text { Principle } 4\end{array}$ & 439 & 27.28 & 7.63 & 638 & 22.02 & 8.04 & $115.71(1,1075)$ & .000 \\
\hline $\begin{array}{l}\text { Good Practice Gives Prompt Feedback } \\
\text { Principle } 5\end{array}$ & 439 & 18.28 & 4.85 & 638 & 15.06 & 5.94 & $88.63(1,1075)$ & .000 \\
\hline $\begin{array}{l}\text { Good Practice Emphasizes Time on Task } \\
\text { Principle } 6\end{array}$ & 439 & 18.17 & 4.37 & 638 & 16.52 & 4.9 & $32.19(1,1075)$ & .000 \\
\hline $\begin{array}{l}\text { Good Practice Communicates High } \\
\text { Expectations }\end{array}$ & 439 & 24.51 & 4.94 & 638 & 22.28 & 6.06 & $40.80(1,1075)$ & .000 \\
\hline Principle 7 & & & & & & & & \\
\hline $\begin{array}{l}\text { Good Practice Respects Diverse Talents and } \\
\text { Ways of Learning }\end{array}$ & 439 & 26.3 & 6.16 & 638 & 23.56 & 7.14 & $42.78(1,1075)$ & .000 \\
\hline
\end{tabular}


Further analyses (ANOVA's) demonstrated a significant difference between the two groups on 42 of the 45 survey statements. English students rated their instructors higher than math students on all 42 statements where the two groups differed. Table 17 highlights a comparison of the English and Math groups, highlighting the mean score, standard deviation, $F$ score, and significance for all 45 statements. 
Table 17

ANOVA results for each survey statement regarding RQ3

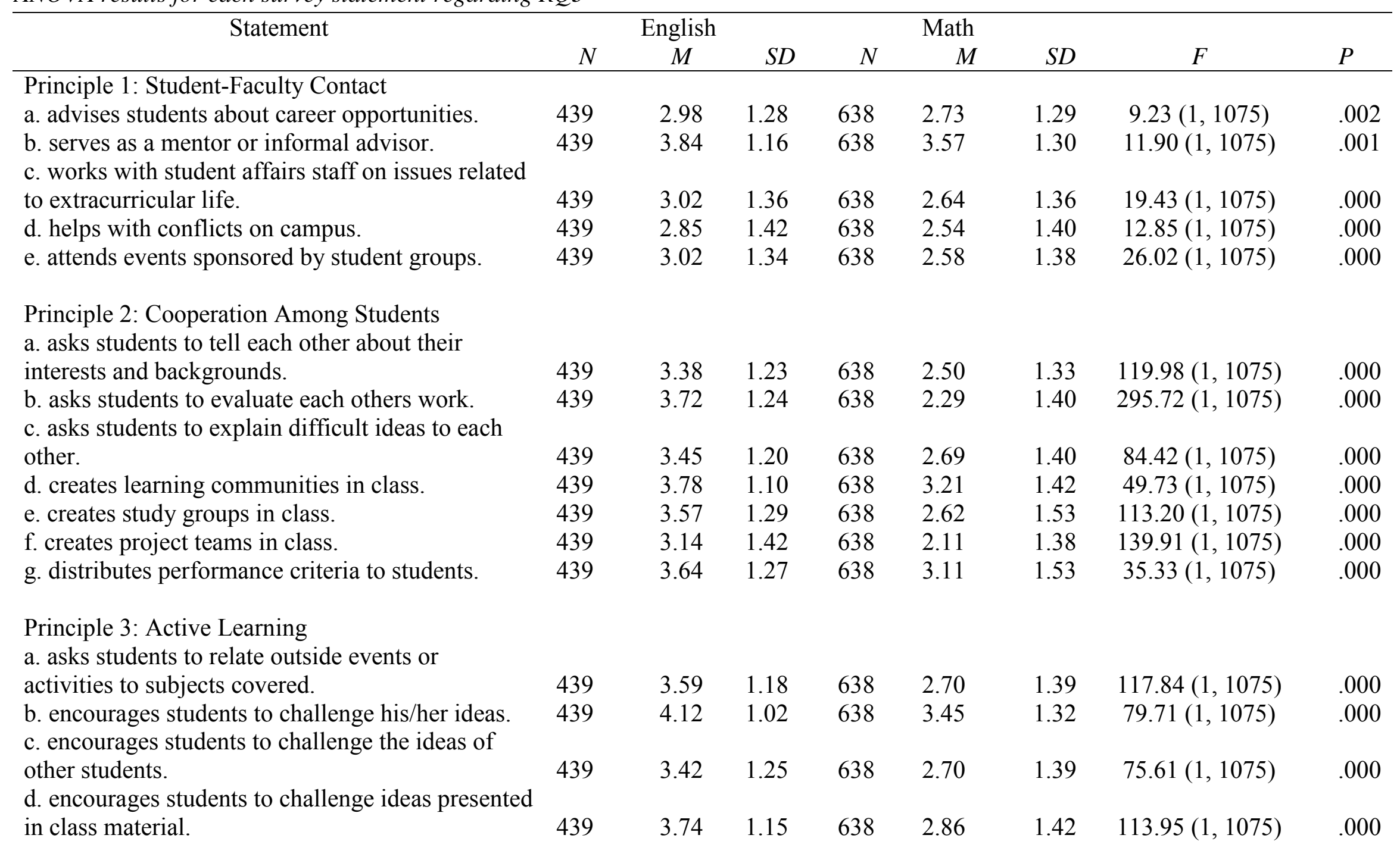


e. gives students concrete real-life situations to analyze.

\section{9}

439

f. uses simulations or role playing in class.

g. works with students to arrange field trips.

h. works with students to arrange volunteer activities.

i. works with students to arrange internships.

Principle 4: Prompt Feedback

a. asks students to schedule conferences to discuss progress.

b. gives students written comments on their strengths and weaknesses.

c. gives students a pretest at the beginning of the term.

d. asks students to keep a log or record of their performance.

e. calls students who miss class.

f. writes notes to students who miss class.

Principle 5: Time on Task

a. helps students set challenging goals for their own learning.

b. underscores the importance of regular work.

c. explains to students the consequences of nonattendance.

d. meets with students who fall behind.

e. If students miss class, my instructor requires them to make up their lost work.

638

638
638

3.31

1.4

2.32

1.37

.98

$21.85(1,1075)$

.000

439

439

$2.10 \quad 1.31$

638
638

1.58

1.09

$2.04 \quad 1.32$

1.65

1.12

$49.59(1,1075)$

$27.41(1,1075)$

.000

$\begin{array}{lll}2.93 & 1.38 \quad 638\end{array}$

2.50

1.37

$25.84(1,1075)$

.000

$4.30 \quad .96 \quad 638$

2.75

1.47

$378.25(1,1075)$

.000

$\begin{array}{lll}3.59 & 1.44 \quad 638\end{array}$

3.19

1.63

$16.70(1,1075)$

.000

3.28

1.46

638

3.05

1.65

$5.08(1,1075)$

.024

$\begin{array}{ll}1.82 & 1.26\end{array}$

638

1.68

1.18

$3.31(1,1075)$

$30.37(1,1075)$

.069

.000

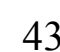

$3.64 \quad 1.16$

1.39

638

3.07

1.41

$48.42(1,1075)$

.000

1.12

638

2.91

1.49

$12.42(1,1075)$

.000

Principle 6: High Expectations a. emphasizes the importance of holding high standards for academic achievement.
$4.12 \quad 1.02$

638

3.76

1.26

$24.54(1,1075)$

.000 
b. makes clear his/her expectations orally at the beginning of each course. beginning of each course.

439

$$
4.26
$$

d. helps students set challenging goals for their own learning.

e. explains to students what will happen if they do not complete their work on time.

f. periodically discusses how well the class is doing during the course of the semester.

\section{Principle 7: Diverse Ways of Learning}

a. encourages students to speak up when they don't understand.

b. discourages snide remarks, sarcasm, kidding, and behaviors that embarrass others.

c. uses diverse teaching activities to address a broad spectrum of students.

d. selects readings and designs activities related to students' backgrounds.

e. tries to find out about his/her students' learning styles at the beginning of the course.

f. tries to find out about his/her students' interests at the beginning of the course.

g. tries to find out about his/her students'

backgrounds at the beginning of the course.

$$
638
$$

4.11

1.10

$5.48(1,1075)$

.82

638

4.48

638

3.71

638

3.49

638

2.54

638

3.18

638

3.24

1.47

.87

$.000(1,1075)$

.998

$\begin{array}{llll}3.47 & 1.36 & 638 & 2.90\end{array}$




\section{Research Question 4}

Research Question 4 asked if there were statistically significant differences between the perceptions of instructors teaching in developmental English/writing courses and instructors teaching in developmental mathematics courses regarding their use of the 7 Principles for Good Practice. Analysis of Research Question 4 determined that statistical differences existed between the two groups on three of the seven principles. A total of 29 instructors completed surveys for this question. There were 13 instructors who taught developmental English or writing courses, and 16 instructors taught developmental math courses. A two-group multivariate analysis of variance (MANOVA) was conducted to determine if differences existed between the mean scores of instructors on the seven dependent variables. The MANOVA yielded a score of $F$ (7, $21)=4.03, p<.05$, demonstrating a significant difference between math instructors and English instructors in regard to the seven dependent variables. A subsequent analysis of variance on each of the dependent variables produced a significant difference between groups (Table 18) on Principle 2 (Good Practice Encourages Cooperation Among Students), Principle 3 (Good Practice Encourages Active Learning), and Principle 4 (Good Practice Gives Prompt Feedback). 
Table 18

ANOVA results for each dependent variable where groups differed for RQ4

Principle English Instructor Math Instructor

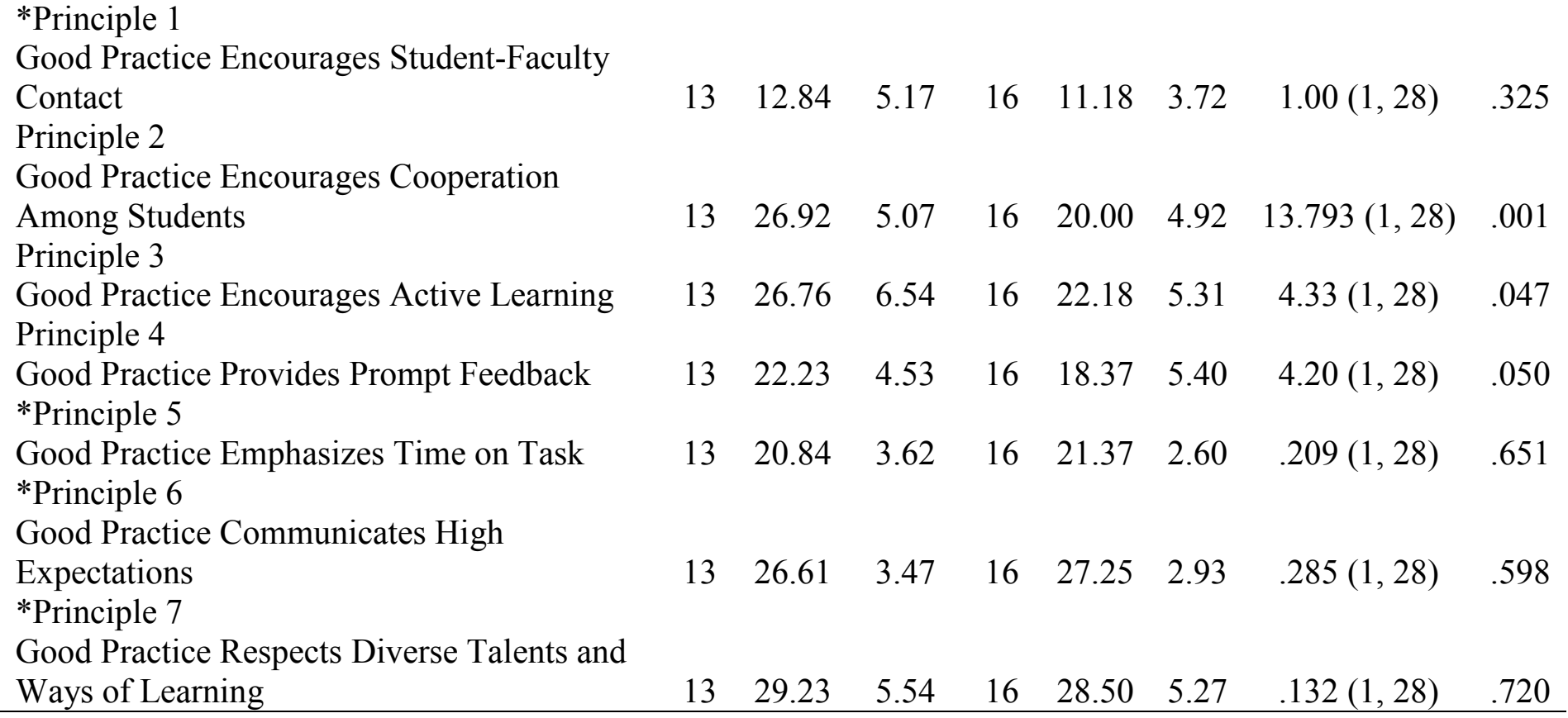

*No significant difference between groups

Table 19 highlights a comparison of the English and Math groups, highlighting the mean score, standard deviation, $F$ score, and significance for each statement. The survey instrument used a Likert-type scale ( 5 = very often, $4=$ often, $3=$ occasionally, $2=$ rarely, and $1=$ never $)$. English instructors rated themselves higher on eight of the statements, including two statements from Principle 2 (Good Practice Encourages Cooperation Among Students), three statements from Principle 3 (Good Practice Encourages Active Learning), and three statements from Principle 4 (Good Practice Gives Prompt Feedback). Math instructors rated themselves higher on one statement from Principle 6 (Good Practice Communicates High Expectations). 
Table 19

ANOVA results for each survey statement regarding RQ4

\begin{tabular}{|c|c|c|c|c|c|c|c|c|}
\hline \multirow[t]{2}{*}{ Statement } & \multicolumn{4}{|c|}{ English Instructor } & \multicolumn{2}{|c|}{ Math Instructor } & \multirow[b]{2}{*}{$F(d f)$} & \multirow[b]{2}{*}{ Sig. } \\
\hline & $N$ & $M$ & $S D$ & $N$ & $M$ & $S D$ & & \\
\hline $\begin{array}{l}\text { Principle 2: Cooperation Among Students } \\
\text { b. I ask students to evaluate each others work. } \\
\text { d. I create learning communities in my classroom }\end{array}$ & $\begin{array}{l}13 \\
13\end{array}$ & $\begin{array}{l}4.38 \\
3.92\end{array}$ & $\begin{array}{l}.96 \\
.89\end{array}$ & $\begin{array}{l}16 \\
16\end{array}$ & $\begin{array}{l}1.87 \\
2.81\end{array}$ & $\begin{array}{l}.80 \\
1.37\end{array}$ & $\begin{array}{c}58.56(1,27) \\
9.13(1,27)\end{array}$ & $\begin{array}{l}.000 \\
.005\end{array}$ \\
\hline $\begin{array}{l}\text { Principle 3: Active Learning } \\
\text { a. I ask students to relate outside events or activities to the } \\
\text { subjects covered in the course. } \\
\text { c. I encourage students to challenge my ideas. } \\
\text { d. I encourage students to challenge the ideas presented in } \\
\text { readings and other course materials. }\end{array}$ & $\begin{array}{l}13 \\
13 \\
13\end{array}$ & $\begin{array}{l}4.07 \\
4.07\end{array}$ & $\begin{array}{c}.95 \\
1.03\end{array}$ & $\begin{array}{l}16 \\
16\end{array}$ & $\begin{array}{l}3.12 \\
3.06 \\
2.62\end{array}$ & $\begin{array}{l}.88 \\
1.12\end{array}$ & $\begin{array}{l}7.74(1,27) \\
6.25(1,27)\end{array}$ & $\begin{array}{l}.010 \\
.019\end{array}$ \\
\hline $\begin{array}{l}\text { Principle 4: Prompt Feedback } \\
\text { a. I ask students to schedule conferences to discuss their } \\
\text { progress. } \\
\text { b. I give students written comments on their strengths and } \\
\text { weaknesses on exams and papers. } \\
\text { c. I give students a pretest at the beginning of the course }\end{array}$ & $\begin{array}{l}13 \\
13\end{array}$ & $\begin{array}{l}4.84 \\
4.46\end{array}$ & $\begin{array}{c}.37 \\
1.19\end{array}$ & $\begin{array}{l}16 \\
16\end{array}$ & $\begin{array}{l}2.56 \\
3.31 \\
3.12\end{array}$ & $\begin{array}{l}1.03 \\
1.35 \\
1.62\end{array}$ & $\begin{array}{c}6.50(1,27) \\
15.63(1,27) \\
6.07(1,27)\end{array}$ & $\begin{array}{l}.000 \\
.020\end{array}$ \\
\hline $\begin{array}{l}\text { Principle 6: High Expectations } \\
\text { c. makes clear his/her expectations in writing at the } \\
\text { beginning of each course. }\end{array}$ & 13 & 4.53 & .66 & 16 & 4.93 & .25 & $4.99(1,27)$ & .034 \\
\hline
\end{tabular}


Table 20 provides additional information regarding Research Question 4 and demonstrates the combined averages for both math and English instructors in regard to each of the seven principles; this chart provides the averages of statements within each principle where the two groups did not demonstrate a significant difference in their responses. It's notable that instructors rated themselves lowest in areas that encourage student-faculty contact (mean $=2.40)$. The second lowest average came in practices that encourage active learning $($ mean $=2.54)$. The highest average was found in communicating high expectations (mean $=4.43)$.

Table 20

Combined averages on survey statements where instructors do not differ by principle

\begin{tabular}{lcc}
\hline \multicolumn{1}{c}{ Principle } & $N$ & $M$ \\
\hline Principle 1 Good Practice Encourages Student-Faculty Contact & 29 & 2.40 \\
Principle 2 Good Practice Encourages Cooperation Among Students & 29 & 3.36 \\
Principle 3 Good Practice Encourages Active Learning & 29 & 2.54 \\
Principle 4 Good Practice Gives Prompt Feedback & 29 & 3.11 \\
Principle 5 Good Practice Emphasizes Time on Task & 29 & 4.25 \\
Principle 6 Good Practice Communicates High Expectations & 29 & 4.43 \\
Principle 7 Good Practice Respects Diverse Talents and Ways of & & \\
Learning & 29 & 4.16 \\
\hline
\end{tabular}

Table 21 provides a breakdown of the statements where math and English instructors did not differ statistically in their responses. Although Research Question 4 was concerned with the differences between groups, Tables 20 and 21 provide deeper insight in areas where instructors do not differ in their perceptions regarding their practices. 
Table 21

Breakdown of statements where instructors did not differ for RQ4

\begin{tabular}{|c|c|c|c|c|c|c|}
\hline \multirow{2}{*}{ Statement } & \multicolumn{4}{|c|}{$\begin{array}{l}\text { English } \\
\text { Instructor }\end{array}$} & \multicolumn{2}{|c|}{ Math Instructor } \\
\hline & $N$ & $M$ & $S D$ & $N$ & $M$ & $S D$ \\
\hline \multicolumn{7}{|l|}{ Principle 1: Student-Faculty Contact } \\
\hline a. advises students about career opportunities. & 13 & 2.76 & 1.30 & 16 & 2.37 & 1.14 \\
\hline b. serves as a mentor or informal advisor. & 13 & 3.23 & 1.42 & 16 & 2.81 & .98 \\
\hline c. works with student affairs staff on issues related to extracurricular life. & 13 & 2.00 & 1.22 & 16 & 1.56 & .72 \\
\hline d. helps with conflicts on campus. & 13 & 2.38 & 1.19 & 16 & 2.00 & 1.15 \\
\hline e. attends events sponsored by student groups. & 13 & 2.46 & 1.12 & 16 & 2.43 & .89 \\
\hline \multicolumn{7}{|l|}{ Principle 2: Cooperation Among Students } \\
\hline a. asks students to tell each other about their interests and backgrounds. & 13 & 4.00 & 1.41 & 16 & 3.12 & 1.14 \\
\hline c. asks students to explain difficult ideas to each other. & 13 & 4.07 & .86 & 16 & 3.56 & .72 \\
\hline e. creates study groups in class. & 13 & 3.30 & 1.25 & 16 & 2.75 & 1.00 \\
\hline f. creates project teams in class. & 13 & 3.00 & 1.47 & 16 & 2.18 & 1.32 \\
\hline g. distributes performance criteria to students. & 13 & 4.00 & 1.58 & 16 & 3.68 & 1.70 \\
\hline \multicolumn{7}{|l|}{ Principle 3: Active Learning } \\
\hline b. encourages students to challenge his/her ideas. & 13 & 4.00 & 1.00 & 16 & 3.25 & 1.00 \\
\hline e. gives students concrete real-life situations to analyze. & 13 & 3.92 & 1.11 & 16 & 4.00 & .73 \\
\hline f. uses simulations or role playing in class. & 13 & 2.53 & .96 & 16 & 2.43 & 1.20 \\
\hline g. works with students to arrange field trips. & 13 & 1.61 & 1.26 & 16 & 1.25 & .68 \\
\hline h. works with students to arrange volunteer activities. & 13 & 1.38 & .76 & 16 & 1.25 & .57 \\
\hline i. works with students to arrange internships. & 13 & 1.23 & .43 & 16 & 1.18 & .54 \\
\hline \multicolumn{7}{|l|}{ Principle 4: Prompt Feedback } \\
\hline d. asks students to keep a log or record of their performance. & 13 & 3.69 & 1.60 & 16 & 3.75 & 1.43 \\
\hline e. calls students who miss class. & 13 & 2.30 & 1.43 & 16 & 2.50 & 1.15 \\
\hline f. writes notes to students who miss class. & 13 & 3.30 & 1.25 & 16 & 3.12 & 1.36 \\
\hline
\end{tabular}


Principle 5: Time on Task

a. helps students set challenging goals for their own learning.

b. underscores the importance of regular work.

$\begin{array}{llllll}13 & 3.76 & 1.01 & 16 & 3.31 & 1.35 \\ 13 & 4.46 & .77 & 16 & 4.75 & .57 \\ 13 & 4.53 & .96 & 16 & 4.75 & .44 \\ 13 & 3.61 & 1.32 & 16 & 3.93 & 1.03 \\ 13 & 4.46 & .77 & 16 & 4.62 & .71\end{array}$

c. explains to students the consequences of non-attendance.

d. meets with students who fall behind.

$\begin{array}{llll}4.46 & .77 & 16 & 4.62\end{array}$

.71

Principle 6: High Expectations

a. emphasizes the importance of holding high standards for academic achievement.

b. makes clear his/her expectations orally at the beginning of each course.

d. helps students set challenging goals for their own learning.

e. explains to students what will happen if they do not complete their work on time.

f. periodically discusses how well the class is doing during the course of the semester.

\section{Principle 7: Diverse Ways of Learning}

a. encourages students to speak up when they don't understand.

b. discourages snide remarks, sarcasm, kidding, and behaviors that embarrass others.

c. uses diverse teaching activities to address a broad spectrum of students.

d. selects readings and designs activities related to students' backgrounds.

e. tries to find out about his/her students' learning styles at the beginning of the course.

f. tries to find out about his/her students' interests at the beginning of the course.

g. tries to find out about his/her students' backgrounds at the beginning of the course.
13

13

13

$\begin{array}{lllll}4.46 & .77 & 16 & 4.56 & .81 \\ 4.76 & .59 & 16 & 4.93 & .25 \\ 4.07 & 1.03 & 16 & 3.81 & 1.42 \\ & & & & \\ 4.61 & .50 & 16 & 4.75 & .57 \\ & & & & \\ 4.15 & .98 & 16 & 4.25 & .85\end{array}$

$\begin{array}{llllll}13 & 4.69 & .48 & 16 & 4.87 & .34\end{array}$

$\begin{array}{llllll}13 & 4.30 & .85 & 16 & 4.68 & .60\end{array}$

$\begin{array}{llllll}13 & 4.15 & .89 & 16 & 4.00 & 1.15\end{array}$

$\begin{array}{llllll}13 & 3.53 & 1.12 & 16 & 2.75 & 1.43\end{array}$

$\begin{array}{llllll}13 & 3.92 & 1.11 & 16 & 4.00 & 1.15\end{array}$

$\begin{array}{llllll}13 & 4.30 & 1.03 & 16 & 4.31 & 1.07\end{array}$

$\begin{array}{llllll}13 & 4.30 & 1.10 & 16 & 3.87 & 1.31\end{array}$ 


\section{Summary}

This chapter provided an analysis of the four major research questions. First, this study examined whether significant differences existed between the perceptions of students attending developmental courses offered in a decentralized structure and the perceptions of students attending courses offered in a centralized structure in regard to the principles for good practice in undergraduate education. Second, this study examined whether there were significant differences between students and instructors in regard to their perceptions of the principles for good practice occurring in the classroom. The third research question attempted to identify differences between the perceptions of students attending developmental math courses and students attending developmental English courses regarding the principles for good practice. Finally, this study attempted to determine if significant differences existed between math and English instructors' perceptions regarding their practices in the classroom.

Analysis of the first research question determined that significant differences existed between the perceptions of students attending centralized courses and students attending decentralized courses on five of the seven principles, including Principle 1 (Good Practice Encourages Student-Faculty Contact), Principle 2 (Good Practice Encourages Cooperation Among Students), Principle 3 (Good Practice Encourages Active Learning), Principle 5 (Good Practice Emphasizes Time on Task) and Principle 6 (Good Practice Communicates High Expectations). Further analysis demonstrated that students attending decentralized courses rated instructors more favorably than centralized students on 15 of the research statements. Students attending courses offered in a decentralized structure agreed more strongly that instructors advised them about career opportunities and acted as informal advisors than did students attending centralized courses. Students attending decentralized courses agreed more strongly that 
instructors used outside events to make connections to course material; these students also agreed more strongly that instructors scheduled meetings with students to discuss their progress and provided written comments about their strengths and weaknesses on exams and other papers. Decentralized students also agreed more strongly that instructors helped them set challenging goals for learning, explained the consequences of non-attendance, met with students who fell behind to discuss study habits, emphasized the importance of high standards, made expectations clear orally at the beginning of the course, helped students set challenging goals, and explained what would happen if work was not completed on time.

Students attending centralized courses agreed more strongly with five of the statements found in Principle 2 (Good Practice Encourages Cooperation Among Students). These students rated their instructors higher when it came to asking students to evaluate each others work and asking students to explain difficult ideas to each other. Students in the centralized group agreed more strongly that instructors created study groups, created project teams, and distributed performance criteria to help individualize performance standards.

An analysis of Research Question 2 found that there were significant differences between the perceptions of students and instructors in developmental courses on five of the seven principles, including Principle 1 (Good Practice Encourages Student-Faculty Contact), Principle 4 (Good Practice Gives Prompt Feedback), Principle 5 (Good Practice Emphasizes Time on Task), Principle 6 (Good Practice Communicates High Expectation), and Principle 7 (Good Practice Respects Diverse Talents and Ways of Learning). Instructors rated themselves higher on Principle 4, Principle 5, Principle 6 and Principle 7. Further analysis showed that instructors agreed more strongly that they asked students to explain difficult ideas to each other, that they called students who missed class, that they wrote notes to students who missed class, that they 
underscored the importance of regular work, that they explained to students the consequences of non-attendance, and that if students missed class, they required them to make up work. Students agreed more strongly than instructors that their instructors served as mentors or informal advisors, that their instructors worked with student affairs staff on issues related to extracurricular life, and that instructors helped with conflicts on campus.

An analysis of Research Question 3 found that developmental math and developmental English students differed on all seven principles. English students rated their instructors more strongly on all seven principles. After further analysis, it was found that English students rated their instructors more strongly on all 42 of the survey statements that were significantly different. An analysis of Research Question 4 found that developmental math and developmental English instructors in this research study differed on three principles, including Principle 2 (Good Practice Encourages Cooperation Among Students), Principle 3 (Good Practice Encourages active Learning), and Principle 4 (Good Practice Provides Prompt Feedback). Further analysis demonstrated that English instructors agreed more strongly on eight of the nine statements. English instructors agreed more strongly that they created learning communities in their classrooms, that they asked students to evaluate their peers' work, that they asked students to relate outside events or activities to the subjects covered in the course, that they encouraged students to challenge their ideas, that they encouraged students to challenge the ideas presented in readings and other course materials, and that they asked students to schedule conferences to discuss their progress. English instructors also agreed more strongly that they gave students written comments on their strengths and weaknesses on exams and papers and that they gave students a pretest at the beginning of the course. Math instructors agreed more strongly that they made clear their expectations in writing at the beginning of each course. 


\section{Chapter Five:}

\section{Summary, Conclusions, and Recommendations}

The following chapter highlights the conclusions of this research and provides recommendations for practice and future research. This research addressed four research questions. First, the researcher attempted to determine if statistically significant differences existed between the perceptions of students attending centralized and decentralized undergraduate developmental education courses in regard to their instructors' use of the principles for good practice. Second, this study attempted to determine if there were statistically significant differences between students attending developmental education courses and instructors teaching in developmental education courses in regard to their perceptions of the principles for good practice occurring in these courses. Third, this research attempted to determine if there were significant differences in the perceptions of students attending developmental English/writing courses and students attending developmental mathematics courses in regard to each of the seven principles for good practice. Finally, this research attempted to determine if there were significant differences between instructors' perceptions regarding the principles for good practice based on subject taught (i.e. English/writing and mathematics).

\section{Conclusions}

This research determined that statistical differences existed between the groups in each of the four research questions. Research Question 1 compared the centralized group to the decentralized group. Research Question 2 compared students' perceptions to instructors' perceptions. Research Question 3 compared English students to math students, and Research Question 4 compared English instructors to math instructors. Six Appalachian community 
colleges participated in this research project. The survey tool used in this research was an adjusted version of the 7 Principles for Undergraduate Education. The researcher surveyed 1,077 students and 29 instructors in the final weeks of the fall 2010 semester. Eighteen students declined to participate in this study and 13 surveys were discarded as incomplete for a total response rate of $97 \%$ from students. There was a $42 \%$ response rate from instructors in this study.

\section{Research Question 1}

Research Question 1 asked if there were differences between students attending centralized developmental education courses and students attending decentralized courses in regard to seven dependent variables (principles for good practice). The results section demonstrated that the centralized and decentralized groups differed on five of the seven principles. The decentralized group had higher average scores on four of the principles and the centralized group had higher average scores on one principle (Table 22).

Table 22

Principles where groups had highest averages and significant differences were present

\begin{tabular}{ll}
\hline Central & Decentral \\
\hline Principle 2 Cooperation Among Students & Principle 1 Student/Faculty Contact \\
& Principle 3 Active Learning \\
& Principle 5 Time on Task \\
& Principle 6 High Expectations \\
\hline
\end{tabular}

Overall, there were 23 statements out of the 45 where the centralized and decentralized groups differed. One interesting note is that there was a particularly greater difference between the two groups in regard to Principle 2 (Good Practice Encourages Cooperation Among Students) (Table 23). In Principle 2, the centralized group demonstrated higher averages on all five of the statements where there were differences. 
Table 23

Principle 2 statements where groups differed and centralized group had highest averages

Principle 2 Cooperation Among Students

b. asks students to evaluate each others' work

c. asks students to explain difficult ideas to each other

e. creates study groups

f. creates project teams

g. distributes performance criteria

The second highest difference between groups was found in Principle 6 (Good Practice

Communicates High Expectations). The decentralized group had higher averages on four of the statements in Principle 6 (Table 24).

Table 24

Principle 6 statements where groups differed and decentralized group had highest averages Principle 6 High Expectations

a. emphasizes importance of high standards

b. makes expectations clear orally at beginning

c. makes clear expectations in writing

d. helps students set challenging goals

e. explains what will happen if work is not completed on time

The decentralized group also had higher averages than the centralized group on Principle 5

(Good Practice Encourages Time on Task) (see Table 25) and Principle 3 (Good Practice

Encourages Active Learning) (see Table 26).

Table 25

Principle 5 statements where groups differed and decentralized group had highest averages

Principle 5 Time on Task

a. helps students set challenging goals for learning

c. explains consequences of non-attendance

d. meets with students who fall behind to discuss study habits 
Table 26

Principle 3 statements where groups differed and decentralized group had highest averages Principle 3 Active Learning

a. asks students to relate outside events

b. encourages students to challenge his/her ideas

c. concrete real-life issues to analyze

There was a relatively low difference between groups on Principle 1 (Good Practice Encourages Student-Faculty Contact) (Table 27). The decentralized mean score for Principle 1 was 15.48 and the centralized mean was 14.57 (never $=5$; rarely $=10$; occasionally $=15$; often $=$ 20 ; very often $=25)$. It is also important to note that overall these two groups did not differ on 25 of the 45 survey statements.

Table 27

Principle 1 statements where groups differed and decentralized group had highest averages Principle 1 Student Faculty Contact

a. advises students about career opportunities

b. serves as mentor or informal advisor

As stated previously, Boylan et al. (1997) found that students attending centralized courses in two-year public institutions had "... higher rates of retention... and were more likely to be successful..." than students attending decentralized courses. At the same time, Carter, Hashway, and Sandeford-Lyons (1999) found that students who had participated in centralized developmental education courses throughout Louisiana had higher grade point averages than those students who had attended decentralized programs. The findings for Research Question 1 demonstrated that the decentralized group produced higher averages on more of the principles and principle statements than the centralized model where significant differences were detected. These findings do not support the premise that centralized courses are any more effective than 
decentralized programs when it comes to most instructor practices and, for the most part, are inconsistent with the findings of Boylan et al. (1997) and Carter et al. (1999), at least from students' perceptions regarding instructor practices. In fact, the decentralized group had higher averages on 14 of the 20 statements where the two groups differed. Although this study did not examine student success or academic outcomes, the results of the current study tend to be more consistent with Perin (2002) who argued that the effectiveness of centralization or decentralization was inconclusive in terms of student success. Just as Perin (2002) argued in her study, the findings from the current study are somewhat inconsistent, demonstrating that the decentralized group had higher averages on more statements but also scored significantly lower averages in practices that encourage cooperation among students.

There is one further point of interest regarding Research Question 1 that may also provide insight into an area for future study. As demonstrated in their study, Kuh et al. (1997a) found that active learning and cooperation among students were the best predictors of academic gains for undergraduate students. Although the two groups here differed on Principle 3 (Good Practice Encourages Active Learning) the differences were nominal at best, with the ANOVA producing a result of $F(1,758)=6.53, p<.05$ on the overall principle. In addition, in Principle 3 the two groups had more statements with no differences than statements where they did have differences. This was not the case in regard to the differences found between the two groups on Principle 2 (Cooperation Among Students); the centralized group had higher averages on five out of the seven statements with an ANOVA score of $F(1,758)=23.52, p<.001$ on the overall principle (Table 28). 
Table 28

Statements where groups differed and did not differ for Principles 2 and 3 Differences No Differences

Principle 2

Good Practice Encourages Cooperation Among Students $\quad$ b, c, e, f, g, a, d

Principle 3

Good Practice Encourages Active Learning

$\mathrm{a}, \mathrm{b}, \mathrm{e} \quad \mathrm{c}, \mathrm{d}, \mathrm{f}, \mathrm{g}, \mathrm{h}, \mathrm{i}$

It can be argued that there were significantly stronger differences between the two groups on Principle 2 than found on Principle 3 (or any other principle) and that these differences may have had some affect on the overall academic and success outcomes of students as argued by Kuh et al. (1997a). Unfortunately the current study falls short here, because it was not concerned with correlating student outcomes with each group's use of principles. Future examination of centralized and decentralized courses may attempt to determine if differences in the practice of encouraging student cooperation is a trend among these programs, and may additionally attempt to correlate student outcomes with this particular practice.

\section{Research Question 2}

Research Question 2 focused on the differences between students and instructors and their perceptions in regard to the principles for good practice. The results in Research Question 2 tend to demonstrate discontinuity between what instructors perceived they were doing in classrooms and what students were experiencing regarding the statements where there were statistically significant differences detected. As noted in Chapter Four, these groups differed on five of the seven principles, with instructors rating themselves higher on average on four of the principles (Table 29). 
Table 29

Principles where groups had highest averages and significant differences were present

\begin{tabular}{cl}
\hline Student & Teacher \\
\hline Principle 1 Student-Faculty Contact & Principle 4 Prompt Feedback \\
& Principle 5 Time on Task \\
& Principle 6 High Expectations \\
& Principle 7 Diverse Ways of Learning \\
\hline
\end{tabular}

It's notable that, even though students rated instructors higher on Principle 1, on average, instructor's rated themselves as rarely to never serving as mentors or informal advisors. At the same time, instructors rated themselves as rarely to never working with student affairs staff on issues related to extracurricular life and helping with conflicts on campus. Instructors also rated themselves as rarely to never working with students to arrange volunteer activities or internships. One important finding for Research Question 2 is that instructors rated themselves stronger on four of the five principles than did the students.

The discontinuity between what instructors perceived they were doing and what students reported experiencing in classes is demonstrated further through analysis of the survey statements. For instance, where students agreed that instructors occasionally underscored the importance of regular work and steady self-pacing (student mean score $=3.19$ ), the instructors felt that they often did so (instructor mean score $=4.62$ ). At the same time, where students found that instructors occasionally discouraged snide remarks, sarcasm, kidding, and behaviors that embarrass others (student mean score $=3.75$ ), the instructors felt they often did so (instructor mean score $=4.51$ ). The same held true when students rated whether their instructor tried to find out about his/her students' backgrounds at the beginning of the course (student mean score $=$ 3.13; instructor mean score $=4.06$ ). 
The implications associated with the overestimation of particular practices by instructors were not configured or analyzed in any empirical manner for this particular research question. It is obvious, however, that some assumptions can be made concerning the causes and effects of the discontinuity between what instructors believed they were doing and what students were experiencing. Research Question 2 determined that instructors and students differed statistically on their responses to 20 out of the 45 survey statements. One reason there may have been a discrepancy between what instructors believed they were doing and what students experienced is that in some instances instructors were just not effectively communicating to all of their students their beliefs or stances in regard to certain concepts. For example, instructors agreed that they often underscored the importance of regular work and steady self-pacing but students agreed that they only experienced this occasionally. It's plausible that this discrepancy existed because instructors had this belief but were less likely to express it to the general population of students within the classroom. Furthermore, it is possible that any actions that might have exemplified these beliefs were reserved by instructors for only those students who were struggling or those students who were not applying themselves within the classroom. In essence, instructors may have underscored the importance of steady work to only those students they determined needed to be reminded of that particular concept. The same theory might hold true in instances where instructors may have needed to discourage snide remarks, sarcasm, kidding, and behaviors that embarrass others. The act of discouraging these behaviors was reserved only for those students who needed it.

Ultimately, one primary effect of this discontinuity between instructor-action and what students experienced is that an opportunity may have been missed for the instructor to make a deeper connection in regard to areas associated with the affective domain. Several of the 
processes conceptualized in the survey align closely with behaviors that promote development along the lines of the affective domain; at the same time, it was within some of these areas where the instructors overestimated their behaviors. For instance, students rated instructors lower when it came to practices that emphasized the importance of holding high standards. This particular statement, along with several others, is a modeling action that ultimately allows instructors to model a specific standard or attitude for the specific purpose of influencing the beliefs or attitudes of students in regard to actions that might help them academically. Instructors may have believed they were communicating these ideas and behaviors within the classroom, but students did not experience them at the same level.

\section{Research Question 3}

Research Question 3 examined the differences between students in developmental English/writing courses and students in developmental math courses in regard to their perceptions of the principles for good practice. These two groups differed on all seven of the principles, with students in English courses rating their instructors higher on 42 of the 45 statements. In essence, students in developmental English classes agreed more strongly than students in developmental math courses that their instructors encouraged student-faculty contact, encouraged cooperation among students, encouraged active learning, provided prompt feedback, emphasized time on task, communicated high expectations, and respected diverse ways of learning. These findings appear to be consistent with the work of Braxton et al. (1998) who argued that faculty in soft paradigmatic disciplines (i.e., English) tend to more often use the principles for good practice. These connections to the findings of Braxton et al. (1998) are demonstrated further in the discussion of Research Question 4. 


\section{Research Question 4}

Research Question 4 focused on the differences in practices as perceived by developmental English/writing instructors and developmental math instructors. According to Braxton et al. (1998), faculty in soft paradigmatic disciplines (i.e., English) tended to use student-centered practices and value student character development more than faculty in hard paradigmatic disciplines (i.e., math). As noted previously in Chapter Four, instructors differed on three of the seven principles, including Principle 2 (Good Practice Encourages Cooperation Among Students), Principle 3 (Good Practice Encourages Active Learning), and Principle 4 (Good Practice Provides Prompt Feedback). English instructors demonstrated higher averages on each of these principles, thus supporting, to some degree, the findings when comparing English students' perceptions to math students' perceptions. In their study, Braxton et al. (1998) found instructors in the College of Arts and Sciences and those in the School of Business differed on four principles, including Principle 1 (Good Practice Encourages Student-Faculty Contact), Principle 3 (Good Practice Encourages Active Learning), Principle 6 (Good Practice Communicates High Expectations), and Principle 7 (Good Practice Respects Diverse Talents and Ways of Learning). Table 30 shows a comparison of the results found in the current study to the findings of Braxton et al. (1998); the soft paradigmatic disciplines demonstrated higher averages in each of these areas where significant differences were detected. The current study tends to reinforce the findings of Braxton et al. (1998), at least in the sense that there were differences between the soft paradigmatic group and the hard paradigmatic group when it came to practices that promote active learning. At the same time, it is important to note that instructors agreed on many of their strengths and weaknesses as demonstrated in Table 21 found in Chapter Four. 
Table 30

Comparison of current study to findings from Braxton et al. (1998)

\begin{tabular}{ll}
\hline Current Study & Braxton et al. (1998) \\
\hline Principle 2 Cooperation Among Students & Principle 1 Student-Faculty Contact \\
Principle 3 Active Learning & Principle 3 Active Learning \\
Principle 4 Prompt Feedback & Principle 6 High Expectations \\
& Principle 7 Diverse Ways of Learning \\
\hline
\end{tabular}

\section{Additional Analysis}

To offer a more complete analysis of Research Questions 1, 2, and 4, an overview is provided in Chapter Four of each principle and corresponding statements where the groups did not differ significantly in their responses; in essence, these are areas where both groups agreed on specific survey statements and demonstrates areas where the two groups perceived practices happening along the scale of often to rarely. Two trends are apparent in regard to areas of weaknesses after examining where groups did not differ statistically in their responses. All three groups in Research Questions 1, 2, and 4 provided their lowest averages for statements where they agreed in regard to student-faculty contact and active learning (Table 31).

Table 31

Combined averages of groups regarding lowest averages where they did not differ

\begin{tabular}{lcc}
\hline Combined Groups & Principle 1 & Principle 3 \\
& Student-Faculty Contact & Active learning \\
RQ1 Centralized and Decentralized & 2.74 & 2.35 \\
RQ2 Students and Teachers & 2.68 & 3.10 \\
RQ4 Instructors & & 2.54 \\
\hline
\end{tabular}


These findings suggest that instructors and students both agreed that the practices associated with statements within these principles where the groups did not differ statistically occur less often than other practices. According to these results, instructors are rarely likely to use the following practices from Principle 1: advising students about career opportunities, serving as a mentor or informal advisor, working with student affairs staff on issues related to extracurricular life, helping with conflicts on campus, and attending events sponsored by student groups. At the same time, instructors are rarely likely to use the following practices from Principle 3, including using simulations or role playing in class, working with students to arrange field trips, working with students to arrange volunteer activities, working with students to arrange internships, or attending events sponsored by student groups.

\section{Recommendations for Practice}

Based on the results of this research, the following recommendations can be made regarding professional practice:

- Regardless of whether or not an institution uses a centralized or decentralized approach to offer developmental courses, the institution should provide its instructors with the resources and support that will help them focus on best practices when working with students attending developmental math or English courses; professional development activities should be encouraged that help instructors develop skills in improving the principles outlined by Chickering and Gamson (1987);

- Areas for improvement should include opportunities to be developed between departments that will allow students to interact with instructors beyond the classroom and increase the visibility of instructors participating in extracurricular activities; this includes engaging students through field trips and internship (or lab) activities outside of the 
classroom; routines and traditions should be integrated into departmental operations that increase interactions between academic and student affairs departments and encourages instructor participation in activities that facilitate student contact beyond the classroom;

- Instructors should also integrate activities into their classroom routines that will allow them to constantly emphasize the importance of regular work and steady application, and they should also include activities that will allow them to learn more about student backgrounds;

- Since this research demonstrated some discontinuity between what instructors perceived they were doing and what students were experiencing in classes, instructors should assess their own practices to determine if they are communicating their intentions effectively;

- Instructors should focus on improving prompt feedback by communicating with students through notes, email, and phone calls when students miss classes;

- Special attention should be paid to the differences found between math and English instructors and students in math and English courses regarding their perceptions pertaining to the 7 Principles for Good Practice; math instructors should improve practice by focusing on activities designed to increase active learning within the classroom and should be encouraged to examine ways of engaging students more actively in content; and math instructors should also schedule meetings with students throughout the semester to discuss student progress.

\section{Recommendations for Further Research}

Recommendations for further research include the following:

- The current study should be expanded to include additional community colleges and include more developmental education instructors; 
- Further examination regarding the use of centralized and decentralized structures for course delivery should be performed and should include a qualitative approach to gain more information regarding the perceptions of students and instructors in these programs;

- Further research might seek to identify colleges that are noted for having highly centralized and/or coordinated developmental education programs for use in a comparison against less coordinated programs to determine if differences exist in practices amongst instructors;

- Further research should also examine differences between two-year and four-year colleges;

- Future research should specifically examine centralized and decentralized programs to determine how each model compares in their approaches and practices regarding the affective domain; this should include correlational study to examine the influence of organizational structure on best practices, student attitudes and motivation, and student outcomes; and

- Finally, additional research should seek to determine if centralized and decentralized developmental programs differ in their practices regarding encouraging student cooperation and if these differences can be correlated with student outcomes.

\section{Concluding Thoughts}

Most of the progress aimed at improving practices in developmental courses over the last four decades has spawned from the student development movement. The work of Chickering and Gamson (1987) is a direct result of this movement, and has been used to identify many of the practices that are intended to improve student success in college. In essence, the 7 Principles for Good Practice in Undergraduate Education are a culmination of a whole body of work dedicated 
to improving student outcomes in post-secondary education, including improving student and faculty interactions, improving student involvement, and increasing active learning.

Various scholars have adapted the work of the student development researchers to formulate frameworks for best practice in developmental education. Boylan (2002), in his book titled What Works: Research Based Practices in Developmental Education, provided an extensive outline of methods and approaches for improving developmental education programs. Among them, Boylan (2002) pointed out the need for institutions to make developmental education a priority and to support these programs by developing a shared vision and philosophy, and by providing the resources necessary that would improve professional development and ultimately improve classroom practices. Boylan (2002) also pointed out that to improve instructional practices, colleges should focus on developing learning communities, accommodate diversity through varied instructional methods, use supplemental instruction, provide frequent testing opportunities, use technology with moderation, provide frequent and timely feedback, use mastery learning, link developmental course content to college level requirements, share instructional strategies, teach critical thinking, teach learning strategies, use active learning techniques, and use classroom assessments. Boylan's (2002) suggestions are directly influenced by the principles for good practice as developed by Chickering and Gamson (1987) and are, in essence, aligned directly with the movement toward a more learner-centered system of postsecondary education.

Some states have developed task forces to help address reform in developmental education within their two-year schools. The community college system of Virginia, for instance, released a report in 2009 citing their goals to reduce the overall need for developmental education, to reduce the time to complete developmental education programs, and to increase the 
numbers of developmental students graduating or transferring from their two-year schools. The report included several recommendations for community colleges in the system, including developing student-support action plans for individual students and providing “... academic and student support services that cultivate the cognitive, affective, and behavioral domains for developmental education students" (Virginia Community College System, 2009, p. 15). These recommendations are rooted in the results echoed by years of research from student development scholars and scholars whose focal points have been on the improvement of developmental education.

As Kuh et al. (1997a) have suggested, the 7 Principles for Good Practice act as process indicators for determining what institutions are doing to facilitate student learning. In their study of baccalaureate and doctoral-granting institutions, Kuh et al. (1997) found that "...gains in general education were highly correlated with student reports of experience with good practices at both types of institutions" (p.48). In particular, Kuh et al. (1997) found that the principles for good practice "...had a positive effect at baccalaureate institutions in terms of increased facultystudent interaction" (p. 55). In their conclusion, Kuh et al. (1997) suggested the following: ...researchers should use process indicators [like the 7 Principles for Good Practice] to monitor the extent to which institutional agents and students are engaged in good practices and to provide regular feedback about the extent to which various academic departments and student affairs units employ good practices. (p. 56)

At the same time, a variety of researchers have supported the centralization of developmental education courses in post-secondary education (Boylan, 2002; Boylan, Bliss, \& Bonham, 1997; Carter, Hashway, \& Sandeford-Lyons, 1999; Gerlaugh, Thompson, Boylan, \& 
Davis, 2007; Kozeracki \& Brooks, 2006). These researchers have demonstrated that students attending centralized programs have had higher GPAs, higher rates of retention, and more success in math and English courses than students attending decentralized programs. Many scholars have argued that developmental education, at its very core, was designed to focus on the affective domain regarding students and learning as much as the cognitive domain (Arendale, 2005; Boylan, \& Bonham, 2007; Higbee, Arendale, \& Lundell, 2005). In effect, researchers have posited that the centralization of developmental education departments within community colleges will create a concentrated focus that can increase the processes necessary to improve student outcomes.

Developmental education courses remain an important function of community colleges in the United States. As stated previously, two-year public institutions are more likely to offer these courses and have more students attending these courses than any other schools. At the same time, these schools are caught on the frontlines of a dynamic public debate that continues to pressure public two-year schools to find ways to cut costs and reduce the length of time students spend in these courses. As more and more citizens continue to avail themselves of the opportunities afforded in post-secondary education, community colleges must continue to look for ways to improve their efficiency and effectiveness for providing developmental coursework and the perpetuation of student success. The current study has attempted to examine important questions concerning practices and perceptions in developmental education programs; it is hoped that this current effort will effectively contribute to the ongoing discussion regarding good practices in these courses. 


\section{References}

American Council on Education (1949). Student personnel point of view. Washington, DC.

Retrieved August 9 ${ }^{\text {th }}, 2009$ from, http://www.naspa.org/search/default.cfm?txtSearch= student $\% 20$ personnel $\% 20$ point $\% 20$ of $\% 20$ view

Appalachian Region Commission (2009). The Appalachian region. Retrieved October 4, 2009, from http://www.arc.gov/index.do?nodeId=2.

Arendale, D. R. (2005). Terms of endearment: Words that define and guide developmental education. Journal of College Reading and Learning, 35(2). 66-82.

Astin, A. W. (1984). Student involvement: A developmental theory for higher education. Journal of College Student Personnel, 25, 297-308.

Astin, A. W. (1997). What matters in college? Four critical years revisited. San Francisco, CA: Jossey-Bass.

Baldridge, J. V. Curtis, D. V. Eker, G. P. \& Riley (1977). Alternative models of governance in higher education. In M. Brown (Ed), ASHE Reader on Organization and Governance in Higher Education (5 ${ }^{\text {th }}$ ed), (pp. 128-142). Boston, MA: Pearson Custom Publishing.

Bangert, A. (2004). The seven principles for good practice: A framework for evaluating online teaching. Internet and Higher Education, 7, 217-232.

Batts, D. (2008). Comparison of student and instructor perceptions of best practices in online technology courses. MERLOT Journal of Online Learning and Teaching, 4(4), 477-489.

Benshoff, J. M., \& Lewis, H. A. (1992). Nontraditional college students. Washington, D.C.: Office of Educational Research and Improvement, U.S. Department of Education.

Berger, J. B. (2000). Organizational behavior at colleges and student outcomes: A new perspective on college impact. The Review of Higher Education, 23(2), 177-198. 
Bolman, L. G., \& Deal, T. E. (2003). Reframing organizations: Artistry, choice, and leadership $\left(3^{\text {rd }}\right.$ ed). San Francisco, CA: Jossey-Bass.

Boylan, H. (2002). What works: Research-based practices in developmental education. Boone, NC: Appalachian State University.

Boylan, H., \& Bonham, B. (2007). 30 Years of developmental education: A retrospective. Journal of Developmental Education, 30(3), 2-4.

Boylan, H., \& Bliss, L. (1997). Program components and their relationship to student achievement. Journal of Developmental Education, 20(3), 2.

Breneman, D. W., \& Haarlow, W. N. (1998). Remediation in higher education. A symposium featuring remedial education: costs and consequences. Fordham Report, 2(9), 1-57. Retrieved October 10, 2009 from ERIC database. (ED422770)

Brothen, T., \& Wambach, C. A. (2004). Refocusing developmental education. Journal of Developmental Education, 28(2), 16-33.

Bryman, A. (1984). Organization studies and the concept of rationality. Journal of Management Studies, 21(4), 391-408.

Carnegie Foundation for the Advancement of Teaching. (2010). Classification listing. Retrieved on June 5, 2010 from http://www. Carnegie foundation.org

Carter, J., Hashway, R. M., \& Sandeford-Lyons, S. T. (1999). Effective organizational structures for remedial programs. College Student Journal, 33(1), 43-48.

Casazza, M. E. (1999). Who are we and where did we come from? Journal of Developmental Education, 21(3), 2-6.

Casazza, M. E., \& Silverman, S. L. (1996). Learning assistance and developmental education: A guide for effective practice. San Francisco, CA: Jossey-Bass. 
Cheng, S. (1990). Change processes in the professional bureaucracy. Journal of Community Psychology, 18, 183-193.

Chickering, A, \& Gamson, Z. (1987). Seven principles for good practice in undergraduate education. AAHE Bulletin. Retrieved November 12, 2009 from, http://www.aahea. org/bulletins/bulletins.htm

Chickering, A, Gamson, Z., \& Barsi, L. (1989). 7 principles for good practice in undergraduate education: Faculty inventory. Racine, WI: The Johnson Foundation, Inc.

Chizmar, J. F., \& Walbert, M. S. (1999). Web-based learning environments guided by principles of good teaching practice. Journal of Economic Education, 30(3), 248-259.

Cohen, A. M. (1998). The shaping of American higher education. San Francisco, CA: JosseyBass.

Cohen, M. D., \& March, J. G. (1986). Leadership in an organized anarchy. In M. Brown (Ed), ASHE Reader on Organization and Governance in Higher Education ( $5^{\text {th }}$ ed), (pp. 1635). Boston, MA: Pearson Custom Publishing.

Cohen, M., March, J., \& Olsen, J. (1972). A garbage can model of organizational choice. Administrative Science Quarterly, 17(1), 1-25.

Cohen, M., March, J., \& Olsen, J. (1979). People, problems, solutions, and the ambiguity of relevance. In J. March \& J. Olsen (Eds) Ambiguity and choice in organizations (pp. 2437). Norway: Bergen.

Cross, K. P. (1980). Our changing students and their impact on colleges: Prospects for a true learning society. Phi Delta Kappan, 630-632.

Crowe, E. (1998). Statewide remedial education policies. Denver, CO: State Higher Education Officers. 
Cruce, T. M., Wolniak, G. C., Seifert, T. A., \& Pascarella, E. T. (2006). Impacts of good practices on cognitive development, learning orientations, and graduate degree plans during the first year of college. Journal of College Student Development, 47(4), 365-383.

Duryea, E. D. (1973). Evolution of university organization. In M. Brown (Ed), ASHE Reader on Organization and Governance in Higher Education (5 $5^{\text {th }}$ ed), (pp. 3-15). Boston, MA: Pearson Custom Publishing.

Evans, N. J., Forney, D. S., \& Guido-DiBrito, F. (1998). Student development in college: Theory, research and practice. San Francisco, CA: Jossey-Bass.

Farazmand, A. (2002). Modern organizations: Theory and practice ( $2^{\text {nd }}$ ed). Wesptort, CT: Praeger Publishers.

Fuller, B., Wood, K., Rapoport, T., \& Dornbusch, S. M. (1982). The organizational context of individual efficacy. Review of Educational Research, 52(1), 7-30.

Gamson, Z. F. (1991). A brief history of the Seven Principles for Good Practice in Undergraduate Education. New Directions for Teaching and Learning, 47, 5-12.

Gerlaugh, K., L., Thompson, L., Boylan, H. \& Davis, H. (2007). National study of developmental education II: Baseline data for community colleges. Research in Developmental Education, 20(4), 1-4.

Graham, C., Cagiltay, K., Lim, B., Craner, J., \& Duffy, T. M. (2001). Seven principles of effective teaching: A practical lens for evaluating online courses. The Technology Source Archives. Retrieved October 4, 2009, from http://technologysource.org/article/seven _principles_of_effective_teaching/

Goldin, C., \& Katz, L. F. (1999). The shaping of higher education: The formative years. Journal of Economic Perspectives, 13(1), 37-62. 
Hammond, T. H. (2004). Herding cats in university hierarchies: Formal structure and policy choice in American research universities. In R. Ehrenberg (Ed) Governing Academia: Who's in charge at the modern university?, (pp. 91-138). Ithaca, NY: Cornell University Press.

Havranek, J. E. \& Brodwin, M. G. (1998). Restructuring universities and colleges: the studentfocused paradigm. Education, 119(1), 115-121.

Higbee, J., Arendale, D., \& Lundell, D. (2005). Using theory and research to improve access and retention in developmental education. New Directions for Community Colleges, 2005(129), 5-15.

Hoyt, J. E., \& Sorensen, C. T. (2001). High school preparation, placement testing, and college remediation. Journal of Developmental Education, 25(2), 26-34.

Hu, S., \& Kuh. G. D. (2001). The effects of student faculty interactions in the 1990s. The Review of Higher Education, 24(3), 309-332.

Ignash, J. (1997). Who should provide postsecondary remedial/developmental education? New Directions for Community Colleges, 100, 5-20.

Jehangir, R. R. (2002). Higher education for whom? The battle to include developmental education at the four-year university. NADE Monograph: Developmental Education: Policy and Practice, 17-35. Retrieved May 3, 2009 from, http://www.nade.net/ publications/monograph.html

Koeckeritz, J., Malkiewicz, J., \& Henderson, A. (2002). The seven principles for good practice: Applications for online education in nursing. Nurse Educator, 27(6), 283-287.

Kolajo, E. F. (2004). From developmental education to graduation: A community college experience. Community College Journal of Research and Practice, 28, 365-371. 
Koljatic, M., \& Kuh, G. D. (2001). A longitudinal assessment of student engagement in good practices in undergraduate education. Higher Education, 42, 351-371.

Kozeracki, C. A., \& Brooks, J. B. (2006). Emerging institutional support for developmental education. New Directions for Community Colleges, 136, 63-73.

Kozeracki, C. (2002). Issues in developmental education. Community College Review, 29(4), 83100.

Kozeracki, C. (2005). Preparing faculty to meet the needs of developmental students. New Directions for Community Colleges, 129, 39-49.

Kuh, G. D. (2003). Organizational theory. In S. R. Komives, \& D. Woodard (Eds), Student services: A Handbook for the profession. San Francisco, CA: Jossey-Bass.

Kuh, G. D., Pace, C. R., \& Vesper, N. (1997a). The development of process indicators to estimate student gains associated with good practices in undergraduate education. Research in Higher Education, 38(4), 435-454.

Kuh, G. D., \& Vesper, N. (1997b). A Comparison of student experiences with good practices in undergraduate education between 1990 and 1994. Review of Higher Education, 21(1) 4361.

Levin, J. (2001). Globalizing the community college: Strategies for change in the 21st century. New York, NY: Palgrave.

Lucas, C. J. (1994). American higher education: A history. New York, NY: St. Martin’s Press.

Lussier, R. N. (2009). Management fundamentals: Concepts, applications, skill development $\left(4^{\text {th }}\right.$ ed). Mason, $\mathrm{OH}$ : Cengage.

Marion, R. (2002). Leadership in education: Organizational theory for the practitioner. Long Grove, IL: Waveland Press, Inc. 
March, J. G., \& Olsen, J. P. (1979). Organizational choice under ambiguity. In J. March \& J. Olsen (Eds) Ambiguity and choice in organizations (pp. 24-37). Norway: Bergen.

McCabe, R. (2000). No one to waste. Denver, CO: Community College Press.

NADE Fact Sheet (2009). Retrieved October 2, 2009, from http://www.nade.net

NCES (2008). Special analysis 2008: Community colleges. Washington, DC: U.S. Department of Education, National Center for Education Statistics. Retrieved August $4^{\text {th }}, 2009$ from, http://nces.ed.gov/programs/coe/2008/analysis/sa02h.asp

NCES (2003). Remedial education at degree-granting postsecondary institutions in fall 2000. Washington, DC: U.S. Department of Education, National Center for Education Statistics. Retrieved October 12, 2008 from, http://nces.ed.gov/pubsearch/pubsinfo. asp?pubid $=2004010$

Olsen, D., Braxton, J. M., Simmons, A. (1998). Affinity disciplines and the use of principles of good practice for undergraduate education. Research in Higher Education, 39(3), 299318.

Pascarella, E. T., Umbach, P., Cruce, T. M., Wolniak, G. C., Kuh, G., Carini, R., et al. (2006). Institutional selectivity and good practices in undergraduate education: How strong is the link? Journal of Higher Education, 77(2), 251-285.

Pascarella, E. T., Wolniack, G. C., Cruce, T. M., \& Blaich, C. F. (2004). Do liberal arts colleges really foster good practices in undergraduate education? Journal of College Student Development. 45(1), 57-74.

Perin, D. (2002). The location of developmental education in community colleges: A discussion of the merits of mainstreaming vs. centralization. Community College Review, 30(1), 2745. 
Perin, D. (2005). Institutional decision making for increasing academic preparedness in community colleges. New Directions for Community Colleges, 2005(129), 27-38.

Peterson, M. W. (1985). Emerging developments in postsecondary organization theory and research: Fragmentation or integration. Educational Researcher, 14(3), 5-12.

Phelan, D. (2000). Enrollment policies and student access at community colleges: Policy paper. Denver, CO: Education Commission of the States. Retrieved October 14, 2008 from ERIC database. (ED439763)

Phipps, R. (1998). College remediation: What it is, what it costs, what's at stake? Washington, DC: Institute for Higher Education Policy. Retrieved October 12, 2008 from ERIC database. (ED429525)

Pontius, J. L., \& Harper, S. R. (2006). Principles for good practice in graduate and professional student engagement. New Directions for Student Services, 115, 47-58.

Ritter, M. E., \& Lemke, K. A. (2000). Addressing the seven principles for good practice in undergraduate education with internet-enhanced education. Journal of Geography in Higher Education, 24(1), 100-108.

Roueche, J. E., \& Roueche, S. D. (1999). High stakes, high performance: Making remedial education work. Washington, DC: Community College Press.

Roueche, J. E., Roueche, S. D., \& Ely, E. E. (2001). Pursuing excellence: The community college of Denver. Community College Journal of Research and Practice, 25, 517-537.

Sheldon, C. Q. (2002). Building a framework for effective community college development. Retrieved November 3, 2008 from ERIC database. (ED477909)

Shwartz, W., \& Jenkins, D. (2007). Promising practices for community college developmental education: A discussion resource for the Connecticut community college system. New 
York, NY: Community College Research Center Teacher's College, Columbia University. Retrieved March 9, 2009 from, http://ccrc.tc.columbia.edu/Publication. asp?UID $=551$

Smittle, P. (2003). Principles for effective teaching in developmental education. Journal of Developmental Education, 26(3), 10. Retrieved from Academic Search Complete database.

Sorcinelli, M. D. (1991). Research findings on the seven principles. New Directions for Teaching and Learning, 47, 13-25.

Spann, M. G. (2000). Remediation: A must for the $21^{\text {st }}$-century learning society. Washington, DC: United States Department of Education. Retrieved October 10, 2008 from ERIC database. (ED439771)

Stephens, D. (2003). Pathways through history: Underprepared students go to college. NADE Monograph: Developmental Education: Pathways to Excellence, 2, 15-35. Retrieved May 3, 2009 from, http://www.nade.net/publications/monograph.html

Thelin, J. R. (2004). A history of American higher education. Baltimore, MD: The Johns Hopkins Press.

Virginia's Community College System (2009). The turning point: Developmental education in Virginia's community colleges. Richmond, VA: Developmental Education Task Force. Retrieved from http://www.vccs.edu/Portals/0/ContentAreas/AcademicServices/ DevelopmentalEducationTaskForce_200909.pdf

Weick, K. E. (1976). Educational organizations as loosely coupled systems. Administrative Science Quarterly, 21(1), 1-19. 


\section{Appendix A.}

\section{Developmental Education Organizational-Type Survey (DEOS)}

Dear College Official:

I am currently working on my doctoral dissertation in Educational Leadership Studies at West Virginia University. My study is titled "A Comparison of Centralized and Decentralized Developmental Education Programs and Students' perceptions Regarding the Seven Principles for Good Practice."

The initial phase of my research requires that I determine the structure used to organize developmental courses in community colleges in the Appalachian region of the United States. By filling out the short survey below, you will assist me in determining the organizational structure used by your institution to offer developmental education courses.

After I have determined the organizational structure utilized by each community college in the Appalachian region, I will then be able to select three institutions that utilize a centralized structure and three institutions that utilize a decentralized structure. Your assistance is greatly appreciated in this initial phase of my research. If you have any questions, please feel free to contact me by email, pkeith@mix.wvu.edu, or telephone at 304-472-9214. The chair of my doctoral committee is Dr. Ernest Goeres; if you have any additional questions, Dr. Goeres can be reached at 304-293-2088.

Sincerely,

Philip M. Keith

1) Name of Community College

2) Select YES or NO for the subject areas in which your school offers remedial/developmental education courses:

\begin{tabular}{|l|l|l||}
\hline & Yes & No \\
\hline Math & & \\
\hline English/writing & & \\
\hline Reading & & \\
\hline My school doesn't offer remedial/developmental courses & & \\
\hline Other & & \\
\hline
\end{tabular}

3) Specify any other subject areas in which your school offers developmental education courses? 
4) Where do students attend remedial/developmental courses?

\begin{tabular}{|l|l|l||}
\hline & Yes & No \\
\hline Remedial math courses are offered in the regular math department & & \\
\hline $\begin{array}{l}\text { Remedial math courses are offered in a department separate from the } \\
\text { regular math department (i.e., in a developmental education department) }\end{array}$ & & \\
\hline Remedial English courses are offered in the regular English department & & \\
\hline $\begin{array}{l}\text { Remedial English courses are offered in a department separate from the } \\
\text { regular English department (i.e., in a developmental education department) }\end{array}$ & & \\
\hline
\end{tabular}

5) Does your school . . .

\begin{tabular}{|l|l|l||}
\hline $\begin{array}{l}\text { employ a full-time individual to chair/head/coordinate a department } \\
\text { designated for developmental education courses? }\end{array}$ & Yes & No \\
\hline $\begin{array}{l}\text { hire full-time instructors for a department specifically designated for } \\
\text { developmental education courses? }\end{array}$ & & \\
\hline
\end{tabular}

6) How does your school organize remedial/developmental education courses?

\begin{tabular}{|l|l|l||}
\hline $\begin{array}{l}\text { Centralized (all developmental courses offered in a department specific for } \\
\text { remedial coursework) }\end{array}$ & Yes & No \\
\hline Decentralized (all remedial courses offered in regular departments) & & \\
\hline $\begin{array}{l}\text { Decentralized but highly coordinated (all remedial courses offered in } \\
\text { regular department but someone is designated to organize and coordinate } \\
\text { developmental courses) }\end{array}$ & & \\
\hline $\begin{array}{l}\text { Mixed (some developmental courses are centralized some courses are } \\
\text { decentralized) }\end{array}$ & & \\
\hline
\end{tabular}

7) If you selected "mixed" for question 6, please list which courses are centralized and which courses are decentralized:

8) Which best describes your remedial/developmental education courses

\begin{tabular}{|l|c|c||}
\hline & Yes & No \\
\hline Credit & & \\
\hline Noncredit & & \\
\hline
\end{tabular}




\section{Appendix B.}

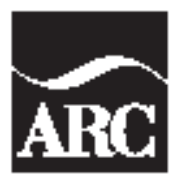

APPALACHIAN REGION

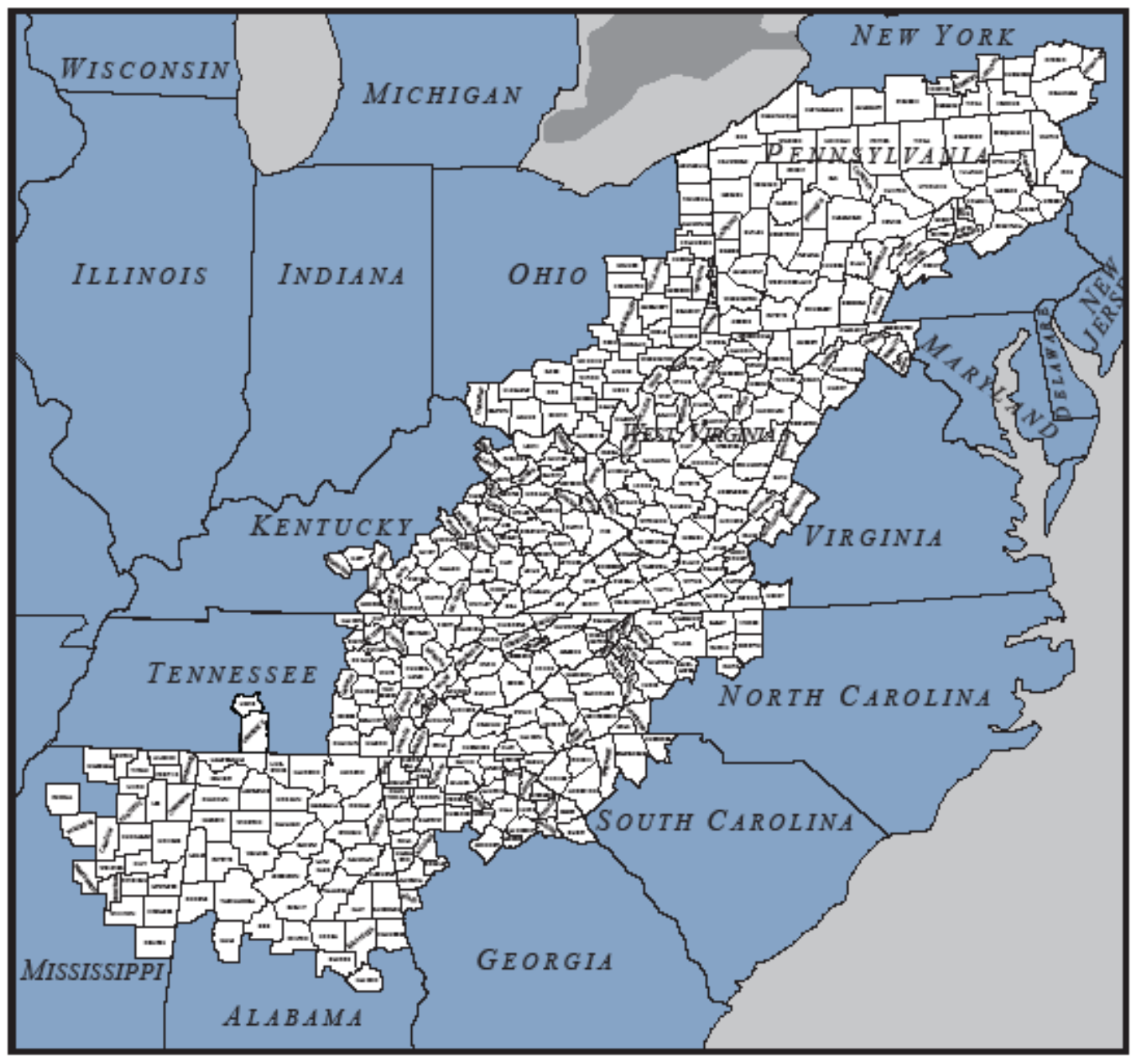

October 8, 2008 


\section{Counties in Appalachia}

Alabama: Bibb, Blount, Calhoun, Chambers, Cherokee, Chilton, Clay, Cleburne, Colbert, Coosa, Cullman, De Kalb, Elmore, Etowah, Fayette, Franklin, Hale, Jackson, Jefferson, Lamar, Lauderdale, Lawrence, Limestone, Macon, Madison, Marion, Marshall, Morgan, Pickens, Randolph, St. Clair, Shelby, Talladega, Tallapoosa, Tuscaloosa, Walker, and Winston

Georgia: Banks, Barrow, Bartow, Carroll, Catoosa, Chattooga, Cherokee, Dade, Dawson, Douglas, Elbert, Fannin, Floyd, Forsyth, Franklin, Gilmer, Gordon, Gwinnett, Habersham, Hall, Haralson, Hart, Heard, Jackson, Lumpkin, Madison, Murray, Paulding, Pickens, Polk, Rabun, Stephens, Towns, Union, Walker, White, and Whitfield

Kentucky: Adair, Bath, Bell, Boyd, Breathitt, Carter, Casey, Clark, Clay, Clinton, Cumberland, Edmonson, Elliott, Estill, Fleming, Floyd, Garrard, Green, Greenup, Harlan, Hart, Jackson, Johnson, Knott, Knox, Laurel, Lawrence, Lee, Leslie, Letcher, Lewis, Lincoln, McCreary, Madison, Magoffin, Martin, Menifee, Metcalfe, Monroe, Montgomery, Morgan, Nicholas, Owsley, Perry, Pike, Powell, Pulaski, Robertson, Rockcastle, Rowan, Russell, Wayne, Whitley, and Wolfe

Maryland: Allegany, Garrett, and Washington

Mississippi: Alcorn, Benton, Calhoun, Chickasaw, Choctaw, Clay, Itawamba, Kemper, Lee, Lowndes, Marshall, Monroe, Montgomery, Noxubee, Oktibbeha, Panola, Pontotoc, Prentiss, Tippah, Tishomingo, Union, Webster, Winston, and Yalobusha

New York: Allegany, Broome, Cattaraugus, Chautauqua, Chemung, Chenango, Cortland, Delaware, Otsego, Schoharie, Schuyler, Steuben, Tioga, and Tompkins

North Carolina: Alexander, Alleghany, Ashe, Avery, Buncombe, Burke, Caldwell, Cherokee, Clay, Davie, Forsyth, Graham, Haywood, Henderson, Jackson, McDowell, Macon, Madison, Mitchell, Polk, Rutherford, Stokes, Surry, Swain, Transylvania, Watauga, Wilkes, Yadkin, and Yancey

Ohio: Adams, Ashtabula, Athens, Belmont, Brown, Carroll, Clermont, Columbiana, Coshocton, Gallia, Guernsey, Harrison, Highland, Hocking, Holmes, Jackson, Jefferson, Lawrence, Mahoning, Meigs, Monroe, Morgan, Muskingum, Noble, Perry, Pike, Ross, Scioto, Trumbull, Tuscarawas, Vinton, and Washington

Pennsylvania: Allegheny, Armstrong, Beaver, Bedford, Blair, Bradford, Butler, Cambria, Cameron, Carbon, Centre, Clarion, Clearfield, Clinton, Columbia, Crawford, Elk, Erie, Fayette, Forest, Fulton, Greene, Huntingdon, Indiana, Jefferson, Juniata, Lackawanna, Lawrence, Luzerne, Lycoming, McKean, Mercer, Mifflin, Monroe, Montour, Northumberland, Perry, Pike, Potter, Schuylkill, Snyder, Somerset, Sullivan, Susquehanna, Tioga, Union, Venango, Warren, Washington, Wayne, Westmoreland, and Wyoming

South Carolina: Anderson, Cherokee, Greenville, Oconee, Pickens, and Spartanburg 
Tennessee: Anderson, Bledsoe, Blount, Bradley, Campbell, Cannon, Carter, Claiborne, Clay, Cocke, Coffee, Cumberland, De Kalb, Fentress, Franklin, Grainger, Greene, Grundy, Hamblen, Hamilton, Hancock, Hawkins, Jackson, Jefferson, Johnson, Knox, Lawrence, Lewis, Loudon, McMinn, Macon, Marion, Meigs, Monroe, Morgan, Overton, Pickett, Polk, Putnam, Rhea, Roane, Scott, Sequatchie, Sevier, Smith, Sullivan, Unicoi, Union, Van Buren, Warren, Washington, and White

Virginia: Alleghany, Bath, Bland, Botetourt, Buchanan, Carroll, Craig, Dickenson, Floyd, Giles, Grayson, Henry, Highland, Lee, Montgomery, Patrick, Pulaski, Rockbridge, Russell, Scott, Smyth, Tazewell, Washington, Wise, and Wythe

The following independent cities in Virginia are also within the Appalachian Region: Bristol, Buena Vista, Covington, Galax, Lexington, Martinsville, Norton, and Radford.

West Virginia: All counties: Barbour, Berkeley, Boone, Braxton, Brooke, Cabell, Calhoun, Clay, Doddridge, Fayette, Gilmer, Grant, Greenbrier, Hampshire, Hancock, Hardy, Harrison, Jackson, Jefferson, Kanawha, Lewis, Lincoln, Logan, Marion, Marshall, Mason, McDowell, Mercer, Mineral, Mingo, Monongalia, Monroe, Morgan, Nicholas, Ohio, Pendleton, Pleasants, Pocahontas, Preston, Putnam, Raleigh, Randolph, Ritchie, Roane, Summers, Taylor, Tucker, Tyler, Upshur, Wayne, Webster, Wetzel, Wirt, Wood, and Wyoming 


\title{
Appendix C.
}

\author{
Letter of Institutional Consent
}

[WVU Letterhead]

Date:

Mr. Philip Keith

Street Address

Town, State Zip Code

Dear Philip:

I am writing to offer my support for your dissertation study research titled "A Comparison of Centralized and Decentralized Developmental Education Programs and Students' Perceptions Regarding the Seven Principles for Good Practice." This letter affirms that you, a doctoral student in the Higher Education Leadership Studies program at West Virginia University, have permission to survey our developmental education instructors and students who are 18 years of age or older. In addition I affirm that you have permission to gather data from student files as outlined in your approved prospectus.

Because you have received approval from West Virginia University's Institutional Review Board for the Protection of Human Subjects, College understands that you have agreed to emphasize the voluntary nature of student participation. Please remind participants that their responses will remain entirely anonymous, confidentiality will be maintained throughout the collection and reporting process, and that their student and/or faculty status will not be affected in any way by their participation or lack thereof.

Thank you for seeking my approval for this very worthy project.

Sincerely,

Signed

Vice President of Academic Affairs College 


\section{Appendix D.}

Letter of Student Informed Consent and Survey Protocol

[WVU letterhead]

\section{Dear Student:}

Thank you for participating in my study titled "A Comparison of Centralized and Decentralized Developmental Education Programs and Students' Perceptions Regarding the Seven Principles for Good Practice." This study is part of my dissertation research for a doctoral degree in educational administrative leadership studies from West Virginia University. This study will be used to further the research on organizational practices concerning developmental education programs. Your participation is requested, but not required. Your rights as a participant are as follows:

- Participation in this study is completely voluntary and whether or not you participate your decision will in no way affect your grades or your status as a student.

- You may stop participating at any point without penalty.

- Your answers will be kept confidential.

- Results will be presented to others in summary form only, without names or other identifying information.

- Precautions have been taken to reduce or eliminate any possible risk such as inconvenience, loss of confidentially, or embarrassment.

For this part of the study, you are being asked to complete a short survey. It should take you 5-15 minutes to complete the survey.

The chairperson and advisor of my committee, Dr. Ernest Goeres, may be contacted at (304) 293-2088, should you have any questions regarding your participation in this research. Additionally, the project has been approved by the WVU Institutional Review Board for the Protection of Human Subjects Research (IRB).

By filling out the survey, you are confirming that you are 18 years of age or older and that you agree to participate in the study of student and faculty perceptions on the principles for good practice. You may contact me at pkeith@mix.wvu.edu or 304-472-9214 if you have questions or concerns about your participation. Thank you for your time and consideration.

Sincerely,

Philip M. Keith 


\section{Appendix E.}

Letter of Staff Informed Consent and Survey Protocol

[WVU letterhead]

\section{Dear Instructor:}

Thank you for considering participating in my study titled "A Comparison of Centralized and Decentralized Developmental Education Programs and Students' Perceptions Regarding the Seven Principles for Good Practice." This study is part of my dissertation research for a doctoral degree in educational administrative leadership studies from West Virginia University. This study will be used to further the research on organizational practices concerning developmental education programs. Your participation is requested, but not required. Your rights as a participant are as follows:

- Participation in this study is completely voluntary and whether you participate or not your decision will in no way affect your employment.

- You may stop participating at any point without penalty.

- Your answers will be kept confidential.

- Results will be presented to others in summary form only, without names or other identifying information.

- Precautions have been taken to reduce or eliminate any possible risk such as inconvenience, loss of confidentially, or embarrassment.

For this part of the study, you are being asked to complete a short survey. It should take you 5-15 minutes to complete the survey.

The chairperson and advisor of my committee, Dr. Ernest Goeres, may be contacted at (304) 293-2088, should you have any questions regarding your participation in this research. Additionally, the project has been approved by the WVU Institutional Review Board for the Protection of Human Research Subjects (IRB).

By filling out the survey you are agreeing to participate in the study of student and faculty perceptions on the principles for good practice. You may contact me at pkeith@mix.wvu.edu, or by telephone at 304-472-9214 if you have questions or concerns about your participation. Thank you for your time and consideration.

Sincerely,

Philip M. Keith 


\section{Appendix F.}

Dear Instructor:

Thank you for participating in my research study. This study is part of my dissertation research for a doctoral degree in educational administrative leadership from West Virginia University. This study will be used to further the research on organizational practices concerning community college courses. Your participation is requested, but not required. Your rights as a participant are as follows:

- Participation in this study is completely voluntary and whether you participate or not your decision will in no way affect your employment.

- You may stop participating at any point without penalty.

- Your answers will be kept confidential.

- Results will be presented to others in summary form only, without names or other identifying information.

- Precautions have been taken to reduce or eliminate any possible risk such as inconvenience, loss of confidentially, or embarrassment.

For this part of the study, you are being asked to complete a short survey. It should take you 5-15 minutes to complete the survey.

My advisor and chairperson of my committee, Dr. Ernest Goeres, may be contacted at (304) 293-7073, should you have any questions regarding your participation in this research. Additionally, the project has been approved by the WVU Institutional Review Board for the Protection of Human Subjects Research (IRB).

By filling out the survey instrument you are agreeing to participate in this study. You may contact me at pkeith@mix.wvu.edu or 304-472-9214 if you have questions or concerns about your participation. Thank you for your time and consideration.

Sincerely,

Philip Keith 


\begin{abstract}
Please answer the following demographic questions to the best of your ability. The entire
\end{abstract} survey should take about 10-15 minutes. Thank you for your participation.

1) At this school do you...

enly teach developmental/remedial courses?

Yes No

$0 \quad 0$

2) Do you teach developmental education courses in ...

math

English/writing

reading

other

$\begin{array}{cc}\text { Yes } & \text { No } \\ \bigcirc & 0 \\ \bigcirc & \bigcirc \\ \square & 0 \\ 0 & \bigcirc\end{array}$

3) What other developmental education courses do you teach?

4) What is your racial or ethnic identification?

Native American

G

Asian or Pacific Islander

Black, African American

Hispanic, Latino

0

White

Other (Please Specify):

5) What is your highest degree achieved?

Bachelors

O

Masters

0

Doctorate

Other (Please Specify): 
6) Gender

Male

Female

7) Are you ...

a full time employee hired specifically to instruct students in developmental/remedial courses?

a part time employee hired specifically to instruct students in developmental/remedial courses?

a full time employee hired to teach a mix of developmental/remedial and regular courses?

a part time employee hired to teach a mix of developmental/remedial and regular courses?

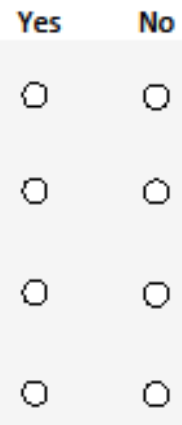

8) Please rate each statement ...

Very Often Occasionally Rarely Never
Often

a. I advise students about career opportunities in their major field.

b. I serve as a mentor or informal advisor to students.

c. I work with student affairs staff on issues related to student extracurricular life and life outside of school.

d. Whenever there is a conflict on campus involving students, I try to help in its resolution.

e. I attend events sponsored by student groups.

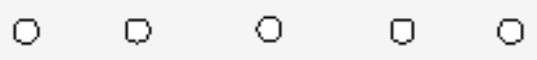
$\begin{array}{lllll}0 & 0 & 0 & 0\end{array}$
$\begin{array}{lllll}0 & 0 & 0\end{array}$
$\begin{array}{lllll}0 & 0 & 0 & 0\end{array}$
$\begin{array}{lllll}0 & 0 & 0 & 0\end{array}$ 
9) Please rate each statement ...

$\begin{aligned} & \text { Very } \\ & \text { O. I ask students to tell each other about } \\ & \text { their interests and backgrounds. }\end{aligned}$
$\begin{aligned} & \text { b. I ask students to evaluate each others } \\ & \text { work. }\end{aligned}$

10) Please rate each statement ...

Very Often Occasionally Rarely Never
Often

a. I ask students to relate outside events or activities to the subjects covered in the course.

b. I encourage students to challenge my ideas.

c. I encourage students to challenge the ideas of other students.

d. I encourage students to challenge the ideas presented in readings or other course materials.

e. I give students concrete real-life situations to analyze.

f. I use simulations or role playing in class.

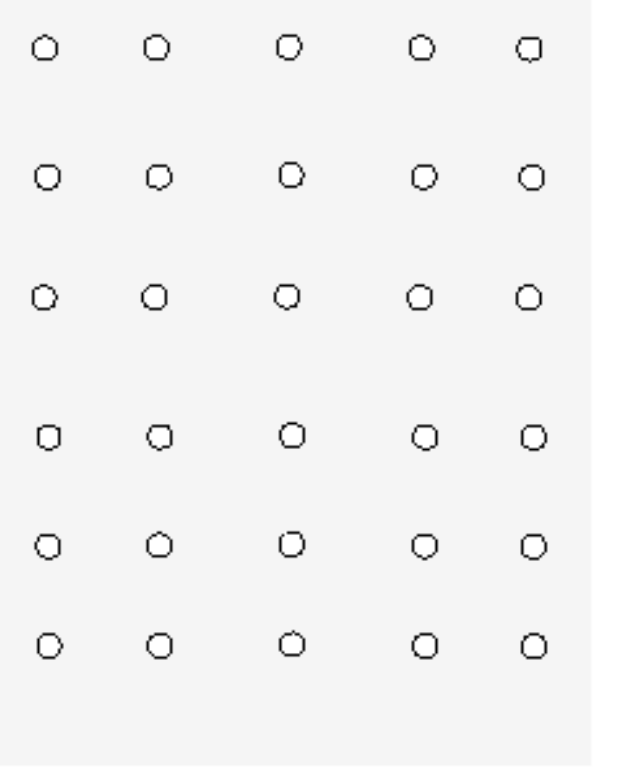


g. I work with students to arrange field trips related to the course.

h. I work with students to arrange volunteer activities related to the course.

I. I work with students to arrange internships related to the course.
$0 \quad 0$
$\bigcirc$
$0 \quad 0$
$0 \quad 0$
$0 \quad 0 \quad 0$
$0 \quad 0$
O
$0 \quad 0$

11) Please rate each statement ...
Very
Often
Often Occasionally Rarely Never
$0 \quad 0$
0
$0 \quad 0$
$\mathrm{O}$

a. I ask students to schedule conferences to discuss their progress. their strengths and weaknesses on exams and papers.

c. I give students a pretest at the beginning of the term to determine how much they know about the subject area.

d. I ask students to keep a log or record of their performance.

e. I call students who miss classes.

f. I write notes to students who miss classes.

12) Please rate each statement ...

Very Often Occasionally Rarely Never
Often

a. I help students set challenging goals for their own learning.

b. I underscore the importance of regular work, steady application, sound self-

pacing, and scheduling.

c. I explain to students the consequences of non-attendance.

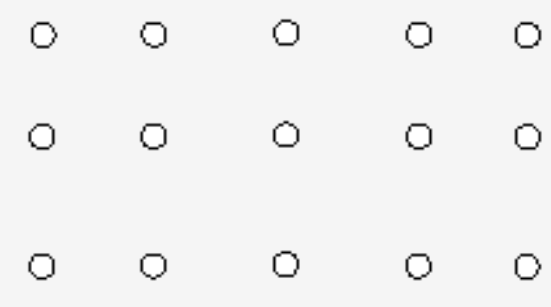


d. I meet with students who fall behind to discuss their study habits, schedules, and other commitments.

e. If students miss class, I require them to make up lost work.

13) Please rate each statement ...

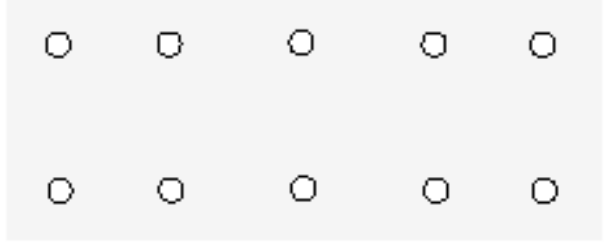

Very Often Occasionally Rarely Never
Often

a. I emphasize the importance of holding high standards for academic achievement.

b. I make clear my expectations orally at the beginning of each course.

c. I make clear my expectations in writing at the beginning of each course.

d. I help students set challenging goals for their own learning.

e. I explain to students what will happen if they do not complete their work on time.

f. I periodically discuss how well the class is doing during the course of the semester.

14) Please rate each statement ...

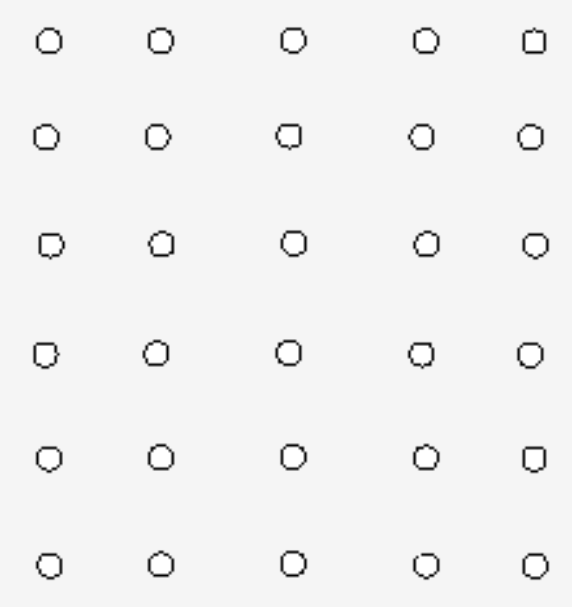

1 Very 2 Often 3 Occasionally 4 Rarely 5 Never
Often

a. I encourage students to speak up when they don't understand.

b. I discourage snide remarks, sarcasm, kidding, and other class behaviors that may embarrass students.

c. I use diverse teaching activities to address a broad spectrum of students.

d. I select readings and design activities related to the background of my students.
0
00
$0 \quad 0 \quad 0$
$0 \quad 0$
$\emptyset$
○
0
$0 \quad 0 \quad 0$
$\begin{array}{ll}0 & 0 \\ 0 & 0 \\ 0 & 0\end{array}$ 


e. I try to find out about my students'
learning styles at the beginning of each
course.




\section{Appendix G.}

Best Practices: Student Version, Dev. English/writing.

Thank you for participating in my research study. This study is part of my dissertation research for a doctoral degree in educational administrative leadership from West Virginia University. This study will be used to further the research on organizational practices concerning community college courses. Your participation is requested, but not required. Your rights as a participant are as follows:

- Participation in this study is completely voluntary and whether you participate or not your decision will in no way affect your grades or status as a student.

- You may stop participating at any point without penalty.

- Your answers will be kept confidential.

- Results will be presented to others in summary form only, without names or other identifying information.

- Precautions have been taken to reduce or eliminate any possible risk such as inconvenience, loss of confidentially, or embarrassment.

For this part of the study, you are being asked to complete a short survey. It should take you 5-15 minutes to complete the survey.

1) What is the name of the college you attend?

\section{2) What is your age?}

18-19

20-22

23-25

26-30

31-35

$35-45$

3) Gender

Female

Male 
4) What is your racial of ethnic identification?

Native American

Asian or Pacific Islander

$\mathrm{O}$

Black, African American

Hispanic, Latino

White

Other

5) If you answered "other" to question three, please describe your race or ethnicity.

6) Please rate each statement ...

\section{Very \\ Often Often Occasionally Rarely Never}

a. My English/writing instructor advises students about career opportunities in their major field.

b. My English/writing instructor serves as a mentor or informal advisor to students.

c. My English/writing instructor works with student affairs staff on issues related to student extracurricular life and life outside of school.

d. Whenever there is a conflict on campus involving students, my English/writing instructor tries to help in its resolution.

e. My English/writing instructor attends events sponsored by student groups.

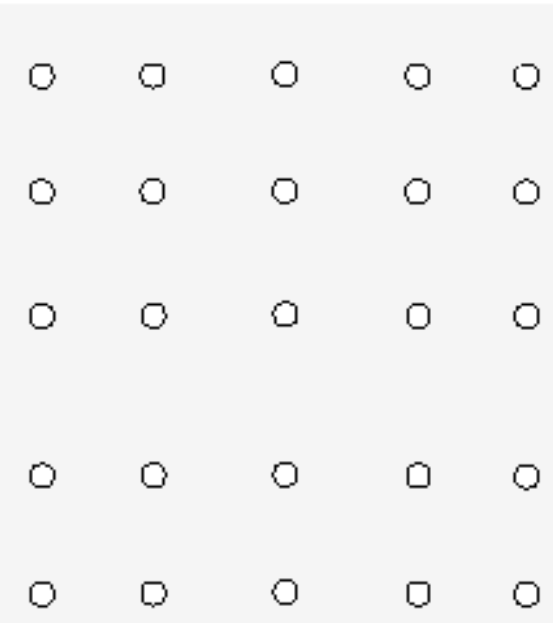


7) Please rate each statement ...

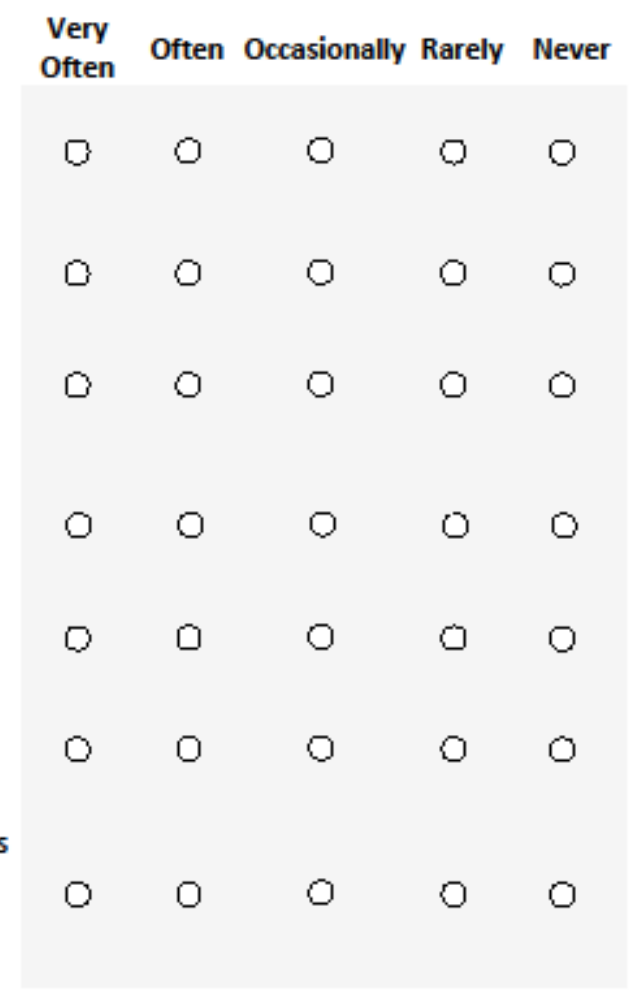

a. My English/writing instructor asks students to tell each other about their interests and backgrounds.

b. My English/writing instructor asks students to evaluate each others work.

c. My English/writing instructor asks students to explain difficult ideas to each other.

d. My English/writing instructor creates learning communities in class.

e. My English/writing instructor creates study groups in class.

f. My English/writing instructor creates project teams in class.

g. My English/writing instructor distributes performance criteria to students so that each person's grade is independent of those achieved by others.

8) Please rate each statement ...

Very Often Occasionally Rarely Never
Often

a. My English/writing instructor asks students to relate outside events or activities to the subjects covered in the course.

b. My English/writing instructor encourages students to challenge his/her ideas.

c. My English/writing instructor encourages students to challenge the ideas of other students.

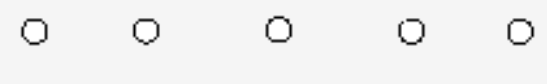

$0 \quad 0 \quad 0 \quad 0$

$\circ \quad 0 \quad 0 \quad 0 \quad 0$ 
d. My English/writing instructor encourages students to challenge the ideas presented in readings or other course materials.

e. My English/writing instructor gives students concrete real-life situations to analyze.

f. My English/writing instructor uses simulations or role playing in class.

g. My English/writing instructor works with students to arrange field trips related to the course.

h. My English/writing instructor works with students to arrange volunteer activities related to the course.

i. My English/writing instructor works with students to arrange internships related to the course.

9) Please rate each statement ...

a. My English/writing instructor asks students to schedule conferences to discuss their progress.

b. My English/writing instructor gives students written comments on their strengths and weaknesses on exams and papers.

c. My English/writing instructor gives students a pretest at the beginning of the term to determine how much they know about the subject area.

d. My English/writing instructor asks students to keep a log or record of their performance.

e. My English/writing instructor calls students who miss classes.

f. My English/writing instructor writes notes to students who miss classes.

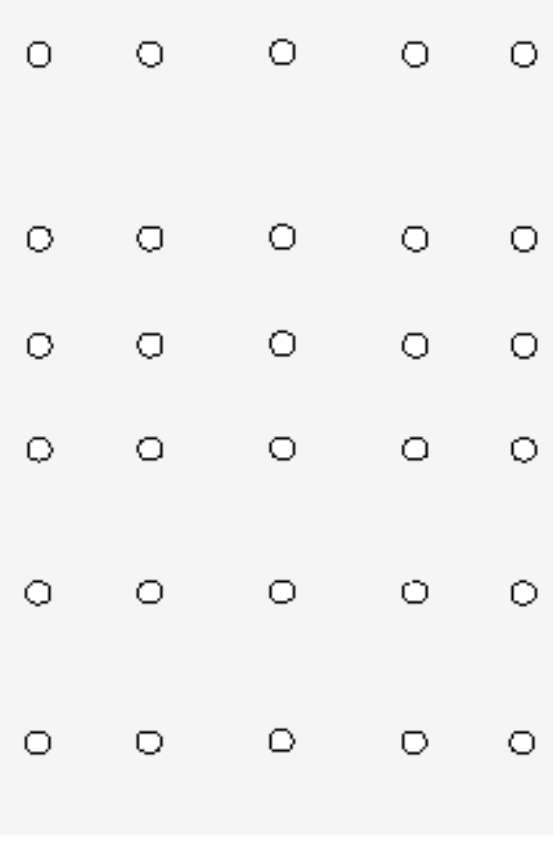

Very

Often

Often Occasionally Rarely Never

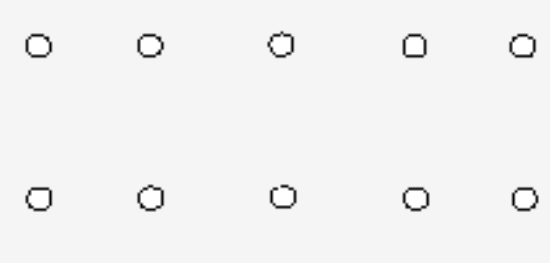

$\bigcirc \quad \circ \quad \circ \quad \circ \quad \circ$

$\begin{array}{lllll}0 & 0 & 0 & 0\end{array}$

$\circ \quad 0 \quad 0 \quad 0$

$\begin{array}{lllll}0 & 0 & 0 & 0\end{array}$ 
10) Please rate each statement ...

Very Often Occasionally Rarely Never
Often

a. My English/writing instructor helps students set challenging goals for their own learning.

b. My English/writing instructor underscores the importance of regular work, steady application, sound selfpacing, and scheduling.

c. My English/writing instructor explains to students the consequences of nonattendance.

d. My English/writing instructor meets with students who fall behind to discuss their study habits, schedules, and other commitments.

e. If students miss class, my English/writing instructor requires them to make up lost work.

11) Please rate each statement ...

a. My English/writing instructor emphasizes the importance of holding high standards for academic achievement.

b. My English/writing instructor makes clear his/her expectations orally at the beginning of each course.

c. My English/writing instructor makes clear his/her expectations in writing at the beginning of each course.

d. My English/writing instructor helps students set challenging goals for their own learning.
O
$\bigcirc$
$\bigcirc \quad \bigcirc$
$\square$
$\bigcirc \quad$
$\bigcirc \quad \bigcirc$
$\square$
$\bigcirc \quad 0$
$0 \quad 0 \quad 0$
$\bigcirc \quad 0$
$\bullet \quad \circ \quad \bigcirc$
$0 \quad 0 \quad 0 \quad 0 \quad 0$

Very

Often

Often Occasionally Rarely Never
$0 \quad 0$
$0 \quad 0$
$\bigcirc \quad \bigcirc$

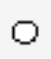
$\bigcirc \quad 0$
$\circ \quad 0$
$\square$
$\circ \quad 0 \quad 0 \quad 0$ 
e. My English/writing instructor explains to students what will happen if they do not complete their work on time.

f. My English/writing instructor periodically discusses how well the class is doing during the course of the semester.

\section{2) Please rate each statement ...}

\begin{tabular}{|c|c|c|c|c|}
\hline $\begin{array}{l}\text { Very } \\
\text { Often }\end{array}$ & Often & Occasionally & Rarely & Never \\
\hline 0 & 0 & $\bullet$ & $\bullet$ & $\bigcirc$ \\
\hline 0 & 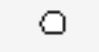 & 0 & $\ominus$ & 0 \\
\hline 0 & 0 & $\bigcirc$ & 0 & 0 \\
\hline 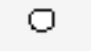 & 0 & $\bigcirc$ & 0 & 0 \\
\hline$\bigcirc$ & 0 & $\mathrm{O}$ & 0 & 0 \\
\hline 0 & 0 & 0 & 0 & $\bullet$ \\
\hline 0 & 0 & 0 & 0 & 0 \\
\hline
\end{tabular}

a. My English/writing instructor encourages students to speak up when they don't understand.

b. My English/writing instructor discourages snide remarks, sarcasm, kidding, and other class behaviors that may embarrass students.

c. My English/writing instructor uses diverse teaching activities to address a broad spectrum of students.

d. My English/writing instructor selects readings and designs activities related to the backgrounds of his/her students.

e. My English/writing instructor tries to find out about his/her students' learning styles at the beginning of each course.

f. My English/writing instructor tries to find out about his/her students' interests at the beginning of each course.

g. My English/writing instructor tries to find out about his/her students' backgrounds at the beginning of each course.

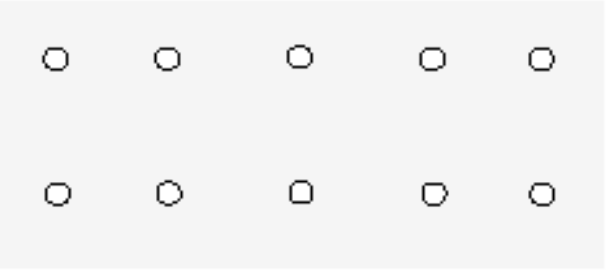




\section{Appendix $\mathbf{H}$.}

Best Practices: Student Version, Dev. Math.

Thank you for participating in my research study. This study is part of my dissertation research for a doctoral degree in educational administrative leadership from West Virginia University. This study will be used to further the research on organizational practices concerning community college courses. Your participation is requested, but not required. Your rights as a participant are as follows:

- Participation in this study is completely voluntary and whether you participate or not your decision will in no way affect your grades or status as a student.

- You may stop participating at any point without penalty.

- Your answers will be kept confidential.

- Results will be presented to others in summary form only, without names or other identifying information.

- Precautions have been taken to reduce or eliminate any possible risk such as inconvenience, loss of confidentially, or embarrassment.

For this part of the study, you are being asked to complete a short survey. It should take you 5-15 minutes to complete the survey.

1) What is the name of the college you attend?

2) What is your age?

18-19

20-22

23-25

26-30

31-35

$35-45$

45 or older

3) Gender

Female

Male

0

0

0

0

0

0

0

0 
4) What is your racial of ethnic identification?

Native American

Asian or Pacific Islander

Black, African American

Hispanic, Latino

White

Other

5) If you answered "other" to question three, please describe your race or ethnicity.

6) Please rate each statement ...

a. My math instructor advises students about career opportunities in their major field.

b. My math instructor serves as a mentor or informal advisor to students.

c. My math instructor works with student affairs staff on issues related to student extracurricular life and life outside of school.

d. Whenever there is a conflict on campus involving students, my math instructor tries to help in its resolution.

e. My math instructor attends events sponsored by student groups.

\section{Very Often Occasionally Rarely Never

Often Uiten Occasiong harely
$0 \quad 0 \quad 0 \quad 0 \quad 0$
$0 \quad 0 \quad 0 \quad 0$
$\begin{array}{lllll}0 & 0 & 0 & 0 & 0\end{array}$
O
$\begin{array}{lllll}0 & 0 & 0 & 0\end{array}$

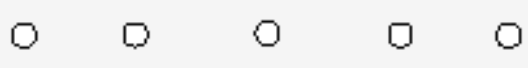


7) Please rate each statement ...

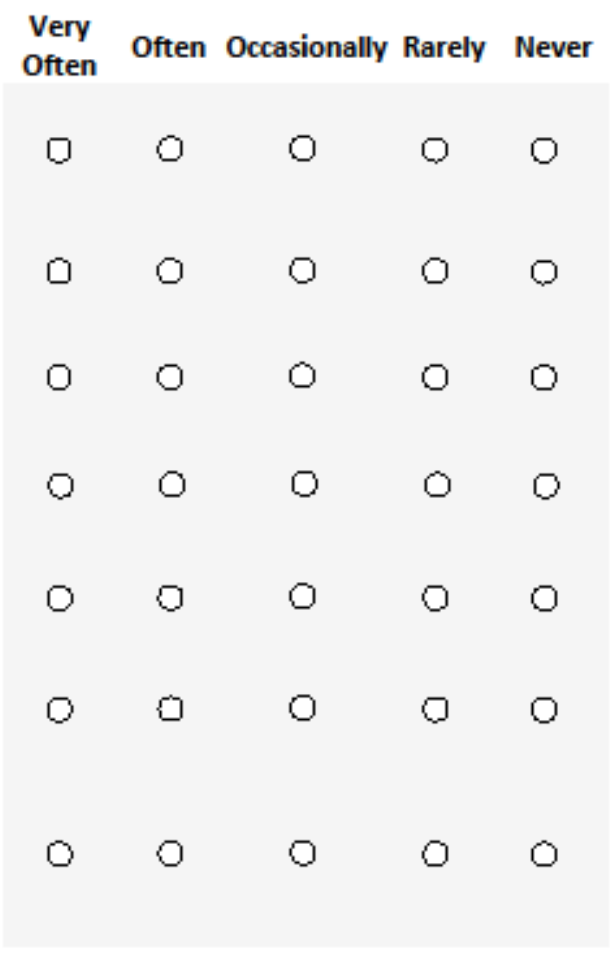

a. My math instructor asks students to tell each other about their interests and backgrounds.

b. My math instructor asks students to evaluate each others work.

c. My math instructor asks students to explain difficult ideas to each other.

d. My math instructor creates learning communities in class.

e. My math instructor creates study groups in class.

f. My math instructor creates project teams in class.

g. My math instructor distributes performance criteria to students so that each person's grade is independent of those achieved by others.

8) Please rate each statement ...

Very Often Occasionally Rarely Never
Often

a. My math instructor asks students to relate outside events or activities to the subjects covered in the course.

b. My math instructor encourages students to challenge his/her ideas.

c. My math instructor encourages students to challenge the ideas of other students.

d. My math instructor encourages students to challenge the ideas presented in readings or other course materials.

e. My math instructor gives students concrete real-life situations to analyze.
$0 \quad 0$

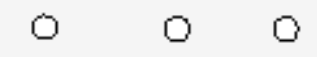
$0 \quad 0$
$0 \quad 0 \quad 0$
$\begin{array}{llll}0 & 0 & 0 & 0\end{array}$
$\begin{array}{lllll}0 & 0 & 0 & 0 & 0 \\ 0 & 0 & 0 & 0 & 0\end{array}$ 
f. My math instructor uses simulations or role playing in class.

g. My math instructor works with students to arrange field trips related to the course.

h. My math instructor works with students to arrange volunteer activities related to the course.

i. My math instructor works with students to arrange internships related to the course.

9) Please rate each statement ...

a. My math instructor asks students to schedule conferences to discuss their progress.

b. My math instructor gives students written comments on their strengths and weaknesses on exams and papers.

c. My math instructor gives students a pretest at the beginning of the term to determine how much they know about the subject area.

d. My math instructor asks students to keep a log or record of their performance.

e. My math instructor calls students who miss classes.

f. My math instructor writes notes to students who miss classes.

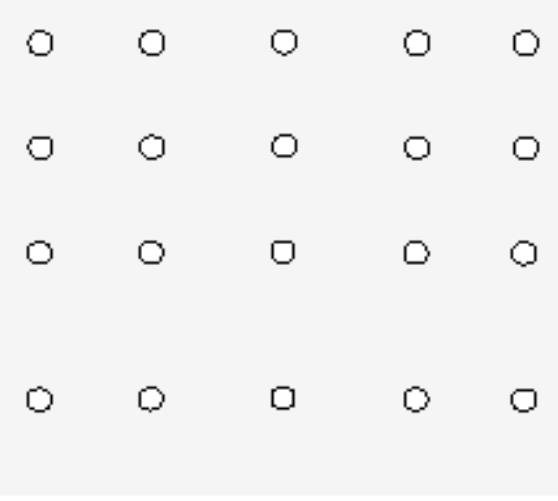

Very Often Occasionally Rarely Never
O $\mathrm{O}$
$\bigcirc$
$\bigcirc \quad \square$
○
$\bigcirc$
$\bigcirc \quad \bigcirc$
O

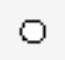
0
$0 \quad 0$
$\bigcirc$
$\bullet \quad \square$
b
00
$\bigcirc$
$\circlearrowleft$
G 0
$\square$ 
10) Please rate each statement ....

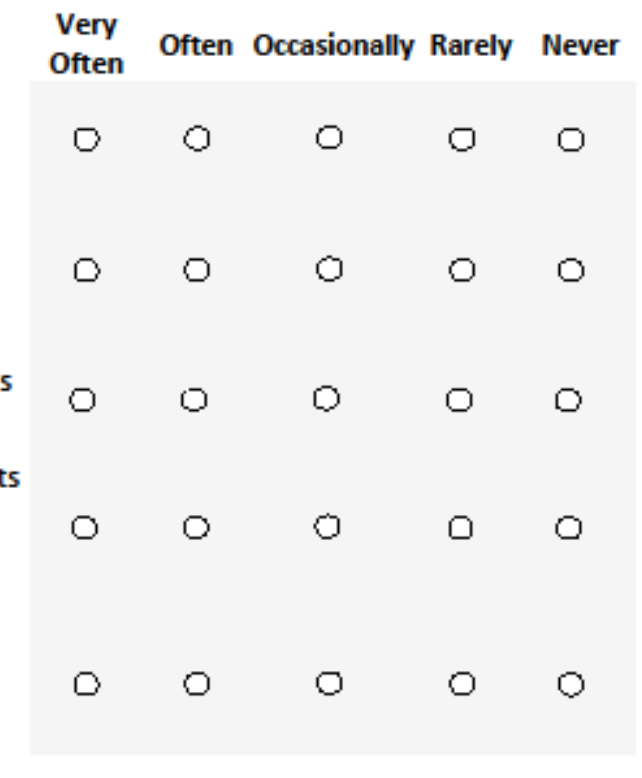

a. My math instructor helps students set challenging goals for their own learning.

b. My math instructor underscores the importance of regular work, steady application, sound self-pacing, and scheduling.

c. My math instructor explains to students the consequences of non-attendance.

d. My math instructor meets with students who fall behind to discuss their study habits, schedules, and other commitments.

e. If students miss class, my math instructor requires them to make up lost work.

11) Please rate each statement ...

a. My math instructor emphasizes the importance of holding high standards for academic achievement.

b. My math instructor makes clear his/her expectations orally at the beginning of each course.

c. My math instructor makes clear his/her expectations in writing at the beginning of each course.

d. My math instructor helps students set challenging goals for their own learning.

e. My math instructor explains to students what will happen if they do not complete their work on time.

f. My math instructor periodically discusses how well the class is doing during the course of the semester.

Very

Often

Often Occasionally Rarely Never

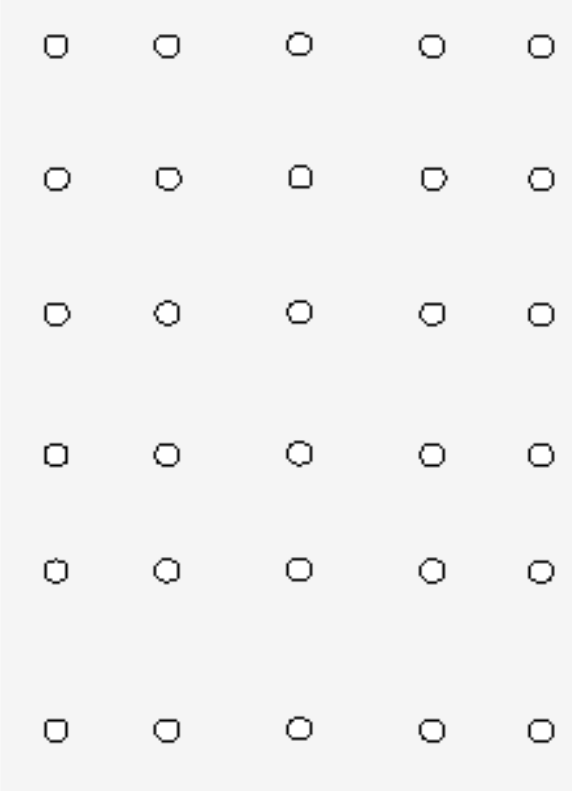


12) Please rate each statement ...

$\begin{aligned} & \text { a. My math instructor encourages } \\ & \text { students to speak up when they don't } \\ & \text { understand. }\end{aligned}$
$\begin{aligned} & \text { b. My math instructor discourages snide } \\ & \text { remarks, sarcasm, kidding, and other class } \\ & \text { behaviors that may embarrass students. }\end{aligned}$
$\begin{aligned} & \text { c. My math instructor uses diverse } \\ & \text { teaching activities to address a broad } \\ & \text { spectrum of students. }\end{aligned}$
$\begin{aligned} & \text { d. My math instructor selects readings and } \\ & \text { designs activities related to the } \\ & \text { backgrounds of his/her students. } \\ & \begin{array}{l}\text { e. My math instructor tries to find out } \\ \text { about his/her students' learning styles }\end{array}\end{aligned}$
$\begin{aligned} & \text { f. My math instructor tries to find out } \\ & \text { about his/her students' interests at the } \\ & \text { beginning of each course. }\end{aligned}$

\section{John H. - Virginia University Libraries,

